\title{
Sanger's Reagent Sensitized Photocleavage of Amide Bond for Constructing Photocages and Regulation of Biological Functions
}

Tingwen Wei ${ }^{1}$, Sheng $\mathrm{Lu}^{1}$, Jiahui Sun ${ }^{2,3}$, Zhijun $\mathrm{Xu}^{1}$, Xiao Yang ${ }^{1}$, Fang Wang ${ }^{1}$, Yang $\mathrm{Ma}^{1}$, Yun Stone Shi ${ }^{2,3,4}$ and Xiaoqiang Chen* 1

${ }^{1}$ State Key Laboratory of Materials-Oriented Chemical Engineering, College of Chemistry and Chemical Engineering, Nanjing Tech University, Nanjing 210009, China.

${ }^{2}$ State Key Laboratory of Pharmaceutical Biotechnology, Nanjing University, Nanjing 210032, China.

${ }^{3}$ Ministry of Education Key Laboratory of Model Animal for Disease Study, Model Animal Research Center, Nanjing University, Nanjing 210032, China.

${ }^{4}$ Chemistry and Biomedicine Innovation Center, Nanjing University, Nanjing 210032, China. 
Chemicals and apparatus.

Synthesis routes and characterization of compounds $1, \mathbf{2}, \mathbf{3}, \mathbf{4}, \mathbf{2 i}, \mathbf{4 i}, \mathbf{5}, \mathbf{6}$ and $\mathbf{7} \ldots \ldots \ldots \ldots . . .3$

UV-vis and fluorescence assays of the probe with irradiation........................................... 6

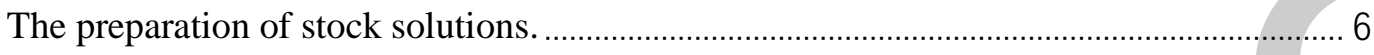

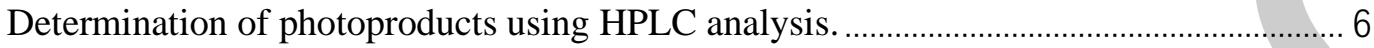

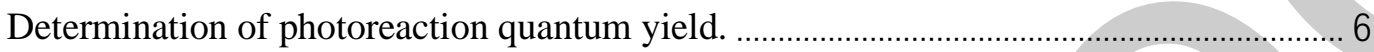

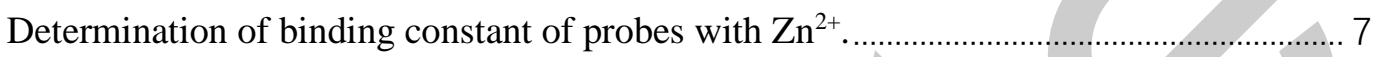

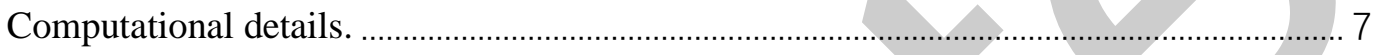

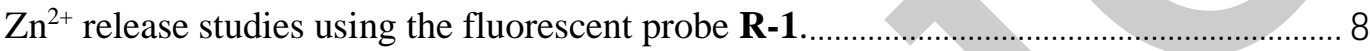

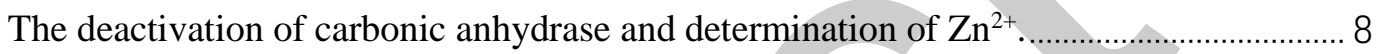

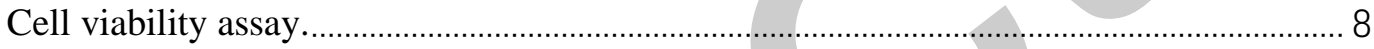

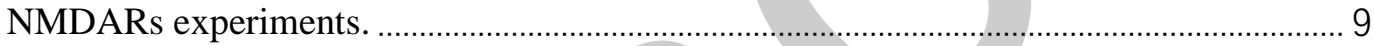

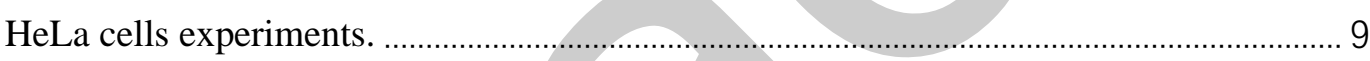

Primary mouse cardiomyocytes experiments. ……….................................................. 9

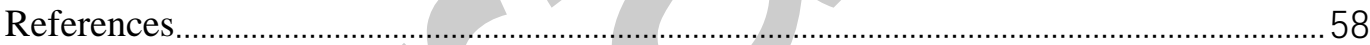


Chemicals and apparatus. Unless noted, all the reagents, solvents and materials were purchased commercially and used without further refinement. All chromatography was performed on silica gel (200-300 mesh). TLCs were developed using mixtures of $\mathrm{CH}_{2} \mathrm{Cl}_{2} /$ methanol $\left(\mathrm{CH}_{3} \mathrm{OH}\right)$ as specified and were visualized with 254 or $365 \mathrm{~nm}$ light. UV-vis absorption spectra and fluorescence emission spectra were obtained by taking sample solutions in $1.0 \mathrm{~cm}$ quartz cuvette with total volumes kept at $3.0 \mathrm{~mL}$. UV-vis spectra were recorded using $\alpha-1860$ A UV-Vis Spectrometer. Fluorescence emission spectra were recorded on RF-5301 PC Spectrofluorophotometer (Shimadzu). The FTIR spectra was measured by Agilent Cary 660 FTIR. ${ }^{1} \mathrm{H}$ NMR and ${ }^{13} \mathrm{C}$ NMR spectra were recorded in deuterium reagents using Bruker 400 with tetramethylsilane as an internal standard substance. Electrospray ionization mass spectra (ESI-MS) were collected on Agilent 1260 HPLC-6500 Q-TOF Mass Spectrometer. The photoreaction was carried out under the UV irradiation by OmniCure S1500 LED (365 nm) with a distance of $5 \mathrm{~cm}$ from the light source to the sample. The optical power density applied to the samples was measured to be $85 \mathrm{~mW} / \mathrm{cm}^{2}$ using an optical power meter CEL-NP2000 (CEAULIGHT).

Synthesis routes and characterization of compounds $1,2,3,4,2 i, 4 i, 5,6$ and 7.

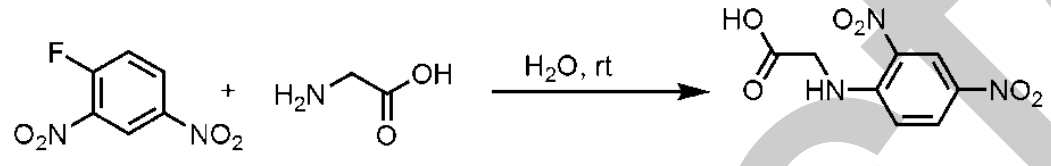

1
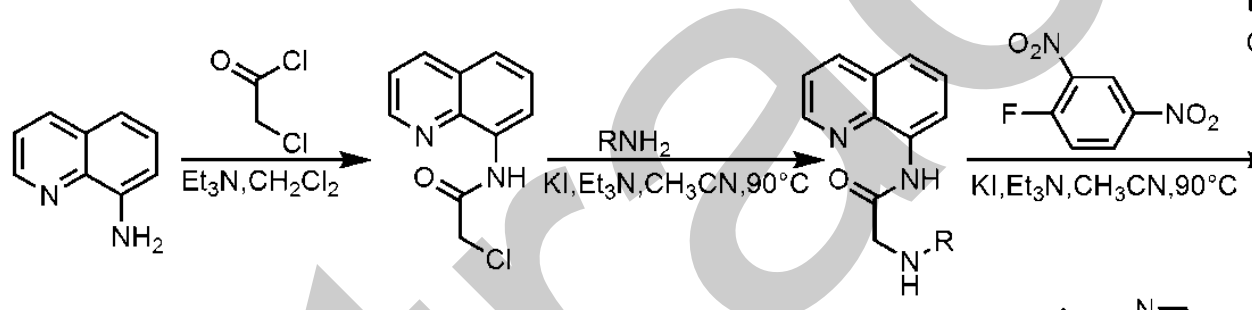<smiles>Nc1cccc2cccnc12</smiles><smiles>[R]NCC([NH])=O</smiles>

$\mathrm{KI}, \mathrm{Et}_{3} \mathrm{~N}, \mathrm{CH}_{3} \mathrm{CN}, 90^{\circ} \mathrm{C}$<smiles>Cc1ccc([N+](=O)[O-])cc1[N+](=O)[O-]</smiles>

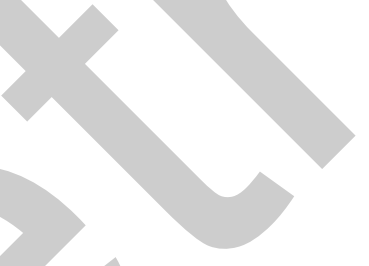<smiles>NCc1ccccn1</smiles>

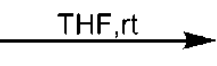<smiles>O=[N+]([O-])c1ccc(NCc2ccccn2)c([N+](=O)[O-])c1</smiles>

2i<smiles>CCCNC[18F]</smiles><smiles>COCCCCCCCOC</smiles><smiles>CCCNc1ccc([N+](=O)[O-])cc1[N+](=O)[O-]</smiles>

$4 \mathrm{i}$

Scheme S1. The synthetic route of compound $\mathbf{1 , 2}, \mathbf{3}, \mathbf{4}, \mathbf{2} \mathbf{i}$ and $\mathbf{4 i}$. 

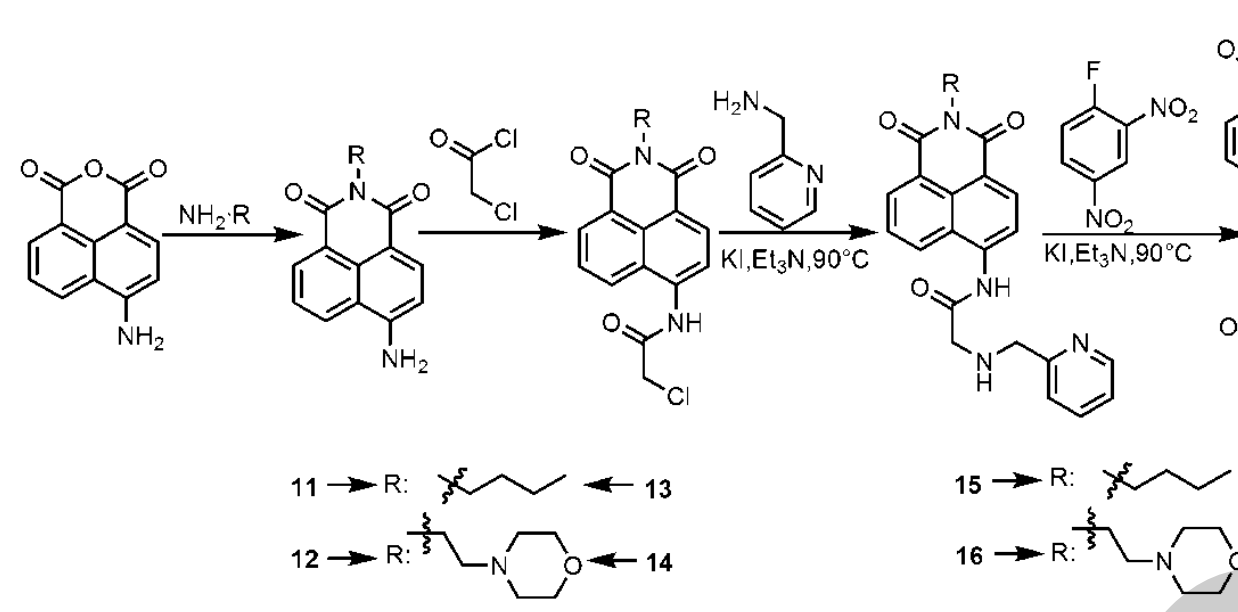<smiles>CC(C)N1CCCC1</smiles>
0<smiles>[Te][Te][Hg]</smiles><smiles>C[As]CN1CCOC(C)C1</smiles>

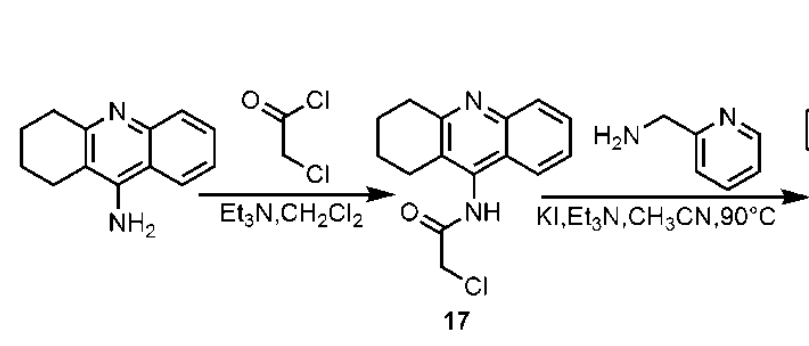

Scheme S1. The synthetic route of compound 5-7.

The synthesis of compound 1 (Scheme S1). ${ }^{1}$ 2,4-Dinitrofluorobenzene (250 mg, $1.34 \mathrm{mmol}$ ) was dissolved in $50 \mathrm{~mL}$ round bottom flask with $20 \mathrm{~mL}$ deionized water. Glycine (120 mg, $1.60 \mathrm{mmol})$ was dissolved in deionized water of $5 \mathrm{~mL}$ and added into flask. Stir overnight at room temperature. After spin-drying, the yellow solid was separated by chromatography column to $164 \mathrm{mg}$, and the yield was $51 \%$. ${ }^{1} \mathrm{H}$ NMR (DMSO-d6, $\left.400 \mathrm{MHz}\right) \delta(\mathrm{ppm}): 13.25(1 \mathrm{H}, \mathrm{s}), 9.01(1 \mathrm{H}, \mathrm{t}, \mathrm{J}=5.52 \mathrm{~Hz}), 8.88(1 \mathrm{H}, \mathrm{d}, \mathrm{J}=2.76$ $\mathrm{Hz}), 8.42(1 \mathrm{H}, \mathrm{d}, \mathrm{J}=8.32 \mathrm{~Hz}), 8.29(1 \mathrm{H}, \mathrm{d}, \mathrm{J}=9.52 \mathrm{~Hz}), 7.11(1 \mathrm{H}, \mathrm{d}, \mathrm{J}=9.6 \mathrm{~Hz}), 4.32(2 \mathrm{H}, \mathrm{d}, \mathrm{J}=5.64 \mathrm{~Hz})$ (Figure S46). ${ }^{13} \mathrm{C}$ NMR (DMSO- $\left.d_{6}, 100 \mathrm{MHz}\right) \delta(\mathrm{ppm}): 170.76,148.31,135.84,130.39,123.87,116.50$, 45.01 (Figure S47). $\mathrm{C}_{8} \mathrm{H}_{6} \mathrm{~N}_{3} \mathrm{O}_{6}{ }^{-}[\mathrm{M}-\mathrm{H}]^{-}, 240.0257$; Found, 240.0254 (Figure S48).

The synthesis of compound 2 (Scheme S1). Compound 8 (0.51 g, $1.74 \mathrm{mmol}$ ) was dissolved in $250 \mathrm{~mL}$ round bottom flask with anhydrous acetonitrile $(100 \mathrm{~mL}) .2,4$-Dinitrofluorobenzene $(0.3871 \mathrm{~g}, 2.08 \mathrm{mmol})$, potassium iodide $(0.288 \mathrm{~g}, 1.74 \mathrm{mmol})$ and triethylamine $(0.484 \mathrm{~mL}, 3.48 \mathrm{mmol})$ were added to the flask. The mixture was stirred and refluxed at $90^{\circ} \mathrm{C}$ for the night. After falling to room temperature, the mixture was dried by a rotary evaporator. The yellow solid product of $686 \mathrm{mg}$ was separated by chromatography column. The yield of 3 was $86 \%$. ${ }^{1} \mathrm{H}$ NMR $\left(\mathrm{CDCl}_{3}-d, 400 \mathrm{MHz}\right) \delta(\mathrm{ppm}): 10.75(1 \mathrm{H}, \mathrm{s}), 8.77(1 \mathrm{H}, \mathrm{d}, \mathrm{J}=$ $4.16 \mathrm{~Hz}), 8.72(1 \mathrm{H}, \mathrm{d}, \mathrm{J}=2.68 \mathrm{~Hz}), 8.69(1 \mathrm{H}, \mathrm{d}, \mathrm{J}=6.4 \mathrm{~Hz}), 8.54(1 \mathrm{H}, \mathrm{d}, \mathrm{J}=3.96 \mathrm{~Hz}), 8.24(1 \mathrm{H}, \mathrm{d}, \mathrm{J}=$ $9.28 \mathrm{~Hz}), 8.16(1 \mathrm{H}, \mathrm{d}, \mathrm{J}=8.24 \mathrm{~Hz}), 7.69(1 \mathrm{H}, \mathrm{t}, \mathrm{J}=7.68 \mathrm{~Hz}), 7.53(2 \mathrm{H}, \mathrm{m}), 7.46(2 \mathrm{H}, \mathrm{m}), 7.39(1 \mathrm{H}, \mathrm{d}, \mathrm{J}=$ $9.32 \mathrm{~Hz}), 7.22(1 \mathrm{H}, \mathrm{t}, \mathrm{J}=6.14 \mathrm{~Hz}), 4.81(2 \mathrm{H}, \mathrm{s}), 4.36(2 \mathrm{H}, \mathrm{s})$ (Figure S49). ${ }^{13} \mathrm{C}$ NMR (DMSO-d6, 100 $\mathrm{MHz}) \delta$ (ppm): 167.40, 156.21, 149.62, 149.33, 148.92, 138.67, 138.00, 137.74, 137.45, 137.01, 134.75, 128.33, 128.23, 127.40, 123.56, 123.16, 122.73, 122.63, 122.56, 120.74, 117.47, 58.98, 57.92 (Figure S50); TOF MS: calcd for $\mathrm{C}_{23} \mathrm{H}_{19} \mathrm{~N}_{6} \mathrm{O}_{5}^{+}[\mathrm{M}+\mathrm{H}]^{+}, 459.1417$; Found, 459.1400 (Figure S51).

The synthesis of compound 3 (Scheme S1) is the same as that of compound 2, the yield $85 \%,{ }^{1} \mathrm{H}$ NMR (DMSO-d6, $400 \mathrm{MHz}) \delta(\mathrm{ppm}): 10.55(1 \mathrm{H}, \mathrm{s}), 8.92(1 \mathrm{H}, \mathrm{d}, \mathrm{J}=4.08 \mathrm{~Hz}), 8.61(2 \mathrm{H}, \mathrm{m}), 8.41(1 \mathrm{H}, \mathrm{d}, \mathrm{J}=$ 
$8.24 \mathrm{~Hz}), 8.26(1 \mathrm{H}, \mathrm{d}, \mathrm{J}=9.40 \mathrm{~Hz}), 7.69(1 \mathrm{H}, \mathrm{d}, \mathrm{J}=8.24 \mathrm{~Hz}), 7.64(1 \mathrm{H}, \mathrm{dd}, \mathrm{J}=4.16 \mathrm{~Hz}, 8.24 \mathrm{~Hz}), 7.57$ (1 $\mathrm{H}, \mathrm{t}, \mathrm{J}=7.98 \mathrm{~Hz}), 7.43(3 \mathrm{H}, \mathrm{m}), 7.33(2 \mathrm{H}, \mathrm{t}, \mathrm{J}=7.5 \mathrm{~Hz}), 7.25(1 \mathrm{H}, \mathrm{t}, \mathrm{J}=7.18 \mathrm{~Hz}), 4.78(2 \mathrm{H}, \mathrm{s}), 4.52(2 \mathrm{H}$, s) (Figure S52). ${ }^{13} \mathrm{C}$ NMR (DMSO-d6, $\left.100 \mathrm{MHz}\right) \delta(\mathrm{ppm}): 167.40,149.34,148.94,138.60,138.38,138.27$, 137.04, 136.33, 134.65, 129.01, 128.32, 128.25, 128.12, 128.00, 127.40, 123.43, 122.74, 122.67, 121.69, 117.38, 57.69, 57.17 (Figure S53); TOF MS: calcd for $\mathrm{C}_{24} \mathrm{H}_{20} \mathrm{~N}_{5} \mathrm{O}_{5}{ }^{+}[\mathrm{M}+\mathrm{H}]^{+}, 458.1467$; Found, 458.1410 (Figure S54).

The synthesis of compound 4 (Scheme S1) is the same as that of compound 2, the yield $79 \%,{ }^{1} \mathrm{H}$ NMR $\left(\mathrm{DMSO}-d_{6}, 400 \mathrm{MHz}\right) \delta(\mathrm{ppm}): 10.52(1 \mathrm{H}, \mathrm{s}), 8.92(1 \mathrm{H}, \mathrm{d}, \mathrm{J}=4.20 \mathrm{~Hz}), 8.60(2 \mathrm{H}, \mathrm{m}), 8.42(1 \mathrm{H}, \mathrm{d}, \mathrm{J}=$ $8.32 \mathrm{~Hz}), 8.28(1 \mathrm{H}, \mathrm{d}, \mathrm{J}=9.48 \mathrm{~Hz}), 7.69(1 \mathrm{H}, \mathrm{d}, \mathrm{J}=8.28 \mathrm{~Hz}), 7.65(1 \mathrm{H}, \mathrm{dd}, \mathrm{J}=4.20 \mathrm{~Hz}, 8.28 \mathrm{~Hz}), 7.57(1$ $\mathrm{H}, \mathrm{t}, \mathrm{J}=7.98 \mathrm{~Hz}), 7.44(1 \mathrm{H}, \mathrm{d}, \mathrm{J}=9.52 \mathrm{~Hz}), 4.54(2 \mathrm{H}, \mathrm{s}), 3.35(2 \mathrm{H}, \mathrm{s}), 1.68(2 \mathrm{H}, \mathrm{m}), 0.84(3 \mathrm{H}, \mathrm{t}, \mathrm{J}=7.32$ $\mathrm{Hz}$ ) (Figure S55). ${ }^{13} \mathrm{C}$ NMR (DMSO- $\left.d_{6}, 100 \mathrm{MHz}\right) \delta(\mathrm{ppm}): 167.42,149.39,148.75,138.56,137.66,137.44$, 137.07, 134.62, 128.32, 128.18, 127.42, 123.66, 122.71, 120.43, 117.22, 56.34, 55.78, 20.22, 11.39 (Figure S56); TOF MS: calcd for $\mathrm{C}_{20} \mathrm{H}_{20} \mathrm{~N}_{5} \mathrm{O}_{5}^{+}[\mathrm{M}+\mathrm{H}]^{+}, 410.1464$; Found, 410.1430 (Figure S57).

Compounds $2 \mathbf{i}$ were synthesized according to published literatures ${ }^{2}$, the yield $81 \% .{ }^{1} \mathrm{H}$ NMR $\left(\mathrm{CD}_{3} \mathrm{CN}, 400\right.$ MHz) $\delta(p p m): 9.67(1 \mathrm{H}, \mathrm{s}), 9.01(1 \mathrm{H}, \mathrm{d}, \mathrm{J}=2.72 \mathrm{~Hz}), 8.61(1 \mathrm{H}, \mathrm{d}, \mathrm{J}=4.56 \mathrm{~Hz}), 8.25(1 \mathrm{H}, \mathrm{t}, \mathrm{J}=4.78 \mathrm{~Hz})$, $7.79(1 \mathrm{H}, \mathrm{t}, \mathrm{J}=7.70 \mathrm{~Hz}), 7.40(1 \mathrm{H}, \mathrm{d}, \mathrm{J}=7.88 \mathrm{~Hz}), 7.32(1 \mathrm{H}, \mathrm{t}, \mathrm{J}=6.14 \mathrm{~Hz}), 7.09(1 \mathrm{H}, \mathrm{t}, \mathrm{J}=9.56 \mathrm{~Hz})$, $3.35(2 \mathrm{H}, \mathrm{s}), 4.78(2 \mathrm{H}, \mathrm{d}, \mathrm{J}=5.04 \mathrm{~Hz})\left(\right.$ Figure S58). ${ }^{13} \mathrm{C} \mathrm{NMR}\left(\mathrm{CD}_{3} \mathrm{CN}, 100 \mathrm{MHz}\right) \delta(\mathrm{ppm}): 149.06,137.70$, 136.57, 131.31, 130.45, 129.42, 128.24, 127.61, 124.23, 117.89, 115.69, 47.09, 27.88 (Figure S59); TOF MS: calcd for $\mathrm{C}_{12} \mathrm{H}_{11} \mathrm{~N}_{4} \mathrm{O}_{4}^{+}[\mathrm{M}+\mathrm{H}]^{+}, 275.0780$; Found, 275.0765 (Figure S27).

Compounds 4i were synthesized according to published literatures ${ }^{3}$, the yield $70 \%$. ${ }^{1} \mathrm{H}$ NMR (DMSO-d6, $400 \mathrm{MHz}) \delta(\mathrm{ppm}): 8.84(1 \mathrm{H}, \mathrm{s}), 8.23(1 \mathrm{H}, \mathrm{d}, \mathrm{J}=9.6 \mathrm{~Hz}), 7.23(1 \mathrm{H}, \mathrm{d}, \mathrm{J}=9.68 \mathrm{~Hz}), 3.45(2 \mathrm{H}$, $\mathrm{m}), 1.66(2 \mathrm{H}, \mathrm{m}), 0.95\left(3 \mathrm{H}, \mathrm{t}, \mathrm{J}=7.38 \mathrm{~Hz}\right.$ ) (Figure S60). ${ }^{13} \mathrm{C}$ NMR (DMSO-d6, $\left.100 \mathrm{MHz}\right) \delta(\mathrm{ppm}): 148.64$, 135.04, 130.38, 130.00, 124.14, 115.74, 44.83, 21.89, 11.57 (Figure S61); TOF MS: calcd for $\mathrm{C}_{9} \mathrm{H}_{10} \mathrm{~N}_{3} \mathrm{O}_{4}{ }^{-}$ [M - H]', 224.0850; Found, 224.0874 (Figure S28).

The synthesis of compound 5 (Scheme S1) is the same as that of compound $2,{ }^{3}$ the yield $52 \%$. ${ }^{1} \mathrm{H}$ NMR $\left(\mathrm{CD}_{3} \mathrm{CN}, 400 \mathrm{MHz}\right) \delta(\mathrm{ppm}): 11.94(1 \mathrm{H}, \mathrm{s}), 8.53(4 \mathrm{H}, \mathrm{m}), 8.28(1 \mathrm{H}, \mathrm{d}, \mathrm{J}=8.12 \mathrm{~Hz}), 8.23(1 \mathrm{H}, \mathrm{d}, \mathrm{J}=9.44$ $\mathrm{Hz}), 8.14(1 \mathrm{H}, \mathrm{d}, \mathrm{J}=4.24 \mathrm{~Hz}), 7.81(1 \mathrm{H}, \mathrm{t}, \mathrm{J}=7.70 \mathrm{~Hz}), 7.73(1 \mathrm{H}, \mathrm{t}, \mathrm{J}=7.90 \mathrm{~Hz}), 7.48(1 \mathrm{H}, \mathrm{d}, \mathrm{J}=7.88$ $\mathrm{Hz}), 7.38(1 \mathrm{H}, \mathrm{d}, \mathrm{J}=9.48 \mathrm{~Hz}), 7.21(1 \mathrm{H}, \mathrm{t}, \mathrm{J}=6.24 \mathrm{~Hz}), 4.99(2 \mathrm{H}, \mathrm{s}), 4.40(2 \mathrm{H}, \mathrm{s}), 4.09(2 \mathrm{H}, \mathrm{t}, \mathrm{J}=7.48$ $\mathrm{Hz}), 1.65(2 \mathrm{H}, \mathrm{m}), 1.41(2 \mathrm{H}, \mathrm{m}), 0.96\left(3 \mathrm{H}, \mathrm{t}, \mathrm{J}=7.36 \mathrm{~Hz}\right.$ ) (Figure S62); ${ }^{13} \mathrm{C}$ NMR (DMSO, $\left.100 \mathrm{MHz}\right) \delta$ (ppm): 168.15, 163.90, 163.36, 156.21, 149.52, 148.63, 140.02, 137.785, 137.34, 132.00, 131.42, 129.54, $128.78,128.26,127.06,124.80,123.71,123.36,122.87,122.82,120.52,120.24,118.45,58.52,57.95,30.13$, 20.27, 14.21 (Figure S63); TOF MS: calcd for $\mathrm{C}_{30} \mathrm{H}_{25} \mathrm{~N}_{6} \mathrm{O}_{7}$ [M-H]-, 581.1863; Found, 581.1828 (Figure S30).

The synthesis of compound $\mathbf{6}$ (Scheme $\mathrm{S} 1$ ) is the same as that of compound 2, the yield $48 \% .{ }^{1} \mathrm{H}$ NMR $\left(\mathrm{CD}_{3} \mathrm{CN}, 400 \mathrm{MHz}\right) \delta(\mathrm{ppm}): 11.94(1 \mathrm{H}, \mathrm{s}), 8.54(4 \mathrm{H}, \mathrm{m}), 8.30(1 \mathrm{H}, \mathrm{d}, \mathrm{J}=8.16 \mathrm{~Hz}), 8.24(1 \mathrm{H}, \mathrm{d}, \mathrm{J}=9.44$ Hz), $8.15(1 \mathrm{H}, \mathrm{d}, \mathrm{J}=4.8 \mathrm{~Hz}), 7.81(1 \mathrm{H}, \mathrm{t}, \mathrm{J}=7.70 \mathrm{~Hz}), 7.73(1 \mathrm{H}, \mathrm{t}, \mathrm{J}=7.92 \mathrm{~Hz}), 7.38(1 \mathrm{H}, \mathrm{d}, \mathrm{J}=9.60 \mathrm{~Hz})$, $7.23(2 \mathrm{H}, \mathrm{m}), 4.99$ (2 H, s), $4.41(2 \mathrm{H}, \mathrm{s}), 4.27$ (2 H, t, J=6.72 HZ), 3.63 (4 H, d, J=4.3 Hz), 2.77 (2 H, s), $1.67(4 \mathrm{H}, \mathrm{m})$ (Figure S64); ${ }^{13} \mathrm{C} \mathrm{NMR}\left(\mathrm{CD}_{3} \mathrm{CN}, 100 \mathrm{MHz}\right) \delta(\mathrm{ppm}): 174.74,168.58,164.65,164.13,155.81$, $149.39,148.26,148.18,140.20,139.34,138.53,132.01,131.53,130.37,129.52,129.10,128.49,127.36$, $125.54,124.74,123.92,123.82,123.77,123.63,120.13,119.36,66.78,59.95,59.26,56.27,54.07,31.15$ (Figure S65); TOF MS: calcd for $\mathrm{C}_{32} \mathrm{H}_{30} \mathrm{~N}_{7} \mathrm{O}_{8}[\mathrm{M}+\mathrm{H}]^{+}, 640.2078$; Found, 640.1980 (Figure S66).

The synthesis of compound 7 (Scheme S1) is the same as that of compound 2, the yield $59 \%$. ${ }^{1} \mathrm{H}$ NMR $\left(\right.$ DMSO- $\left.d_{6}, 400 \mathrm{MHz}\right) \delta(\mathrm{ppm}): 10.62(1 \mathrm{H}, \mathrm{s}), 8.61(1 \mathrm{H}, \mathrm{d}, \mathrm{J}=2.80 \mathrm{~Hz}), 8.45(1 \mathrm{H}, \mathrm{d}, \mathrm{J}=4.20 \mathrm{~Hz}), 8.27(1$ $\mathrm{H}, \mathrm{d}, \mathrm{J}=9.48 \mathrm{~Hz}), 7.96(1 \mathrm{H}, \mathrm{d}, \mathrm{J}=8.28 \mathrm{~Hz}), 7.88(1 \mathrm{H}, \mathrm{d}, \mathrm{J}=8.36 \mathrm{~Hz}), 7.82(1 \mathrm{H}, \mathrm{t}, \mathrm{J}=7.68 \mathrm{~Hz}), 7.66(1 \mathrm{H}$, 
t, J = 7.2 Hz), $7.56(1 \mathrm{H}, \mathrm{d}, \mathrm{J}=7.84 \mathrm{~Hz}), 7.49(1 \mathrm{H}, \mathrm{t}, \mathrm{J}=7.50 \mathrm{~Hz}), 7.33(2 \mathrm{H}, \mathrm{m}), 4.99(2 \mathrm{H}, \mathrm{s}), 4.54(2 \mathrm{H}, \mathrm{s})$, $3.04(2 \mathrm{H}, \mathrm{t}, \mathrm{J}=6.38 \mathrm{~Hz}), 2.75(2 \mathrm{H}, \mathrm{t}, \mathrm{J}=6.30 \mathrm{~Hz}), 1.87(2 \mathrm{H}, \mathrm{m}), 1.76(2 \mathrm{H}, \mathrm{m})$ (Figure S67). ${ }^{13} \mathrm{C} \mathrm{NMR}$ $\left(\mathrm{DMSO}-d_{6}, 100 \mathrm{MHz}\right) \delta(\mathrm{ppm}): 166.98,159.78,56.26,149.51,148.68,137.76,137.66,137.31,129.24$, 128.20, 127.69, 125.96, 124.25, 123.97, 123.73, 123.37, 122.90, 120.37, 58.63, 57.32, 33.78, 25.28, 22.81, 22.45 (Figure S68); TOF MS: calcd for $\mathrm{C}_{27} \mathrm{H}_{25} \mathrm{~N}_{6} \mathrm{O}_{5}[\mathrm{M}+\mathrm{H}]^{+}, 513.1886$; Found, 513.1847 (Figure S69).

Compound 8 was synthesized according to the literature method. ${ }^{4}$ Compounds $9, \mathbf{1 0}, \mathbf{1 5}$, 16, and 18 was synthesized in the same way as compound $\mathbf{8}$. Compounds 11, 12, 13 and 14 were synthesized according to published literatures. ${ }^{5,6}$

UV-vis and fluorescence assays of the probe with irradiation. In a typical experiment, $30 \mu \mathrm{L}$ of the probe $(1 \mathrm{mM})$ was diluted to $2.970 \mathrm{~mL}$ of HEPES buffer solution $(10 \mathrm{mM}, \mathrm{pH}=7.4)$ to obtain the final testing concentration of $10 \mu \mathrm{M}$. The absorption spectra and the fluorescence spectra were respectively recorded after irradiated with ultraviolet light $\left(365 \mathrm{~nm}, 85 \mathrm{~mW} / \mathrm{cm}^{2}\right)$. In this paper, all the photoreactions were carried out under the irradiation by OmniCure S1500 LED UV, and the distance between the sample and the light source was $5 \mathrm{~cm}$.

The preparation of stock solutions. The $1(2.4 \mathrm{mg}, 0.01 \mathrm{mmol}), 2(4.6 \mathrm{mg}, 0.01 \mathrm{mmol}), 3(4.6 \mathrm{mg}, 0.01$ mmol), 4 (4.1 mg, $0.01 \mathrm{mmol}), \mathbf{2 i}(2.7 \mathrm{mg}, 0.01 \mathrm{mmol}), \mathbf{4 i}(2.2 \mathrm{mg}, 0.01 \mathrm{mmol}), 5(5.8 \mathrm{mg}, 0.01 \mathrm{mmol}), \mathbf{6}$ $(6.4 \mathrm{mg}, 0.01 \mathrm{mmol})$ and $7(5.1 \mathrm{mg}, 0.01 \mathrm{mmol})$ was respectively dissolved in dimethyl sulfoxide (DMSO, 10 $\mathrm{mL})$ to obtain $1 \mathrm{mM}$ of stock solution. $\mathrm{Zn}^{2+}$ stock solution $(10 \mathrm{mM})$ was prepared from $\mathrm{Zn}\left(\mathrm{ClO}_{4}\right)_{2} \cdot 6 \mathrm{H}_{2} \mathrm{O}$ with DMSO. $0.5958 \mathrm{~g}$ HEPES was added to the volume bottle of $250 \mathrm{~mL}$ and proper amount of deionized water was added to dissolve the HEPES solid. Use deionized water to set the volume to the calibration line and shake well. The $\mathrm{pH}$ value of the solution was adjusted to 7.4 by trace $\mathrm{NaOH}$ solution to obtain $10 \mathrm{mM}$ HEPES buffer solution.

\section{Determination of photoproducts using HPLC analysis.}

High Performance Liquid Chromatography (HPLC) were obtained at the Waters 1525-2707-2489 system. In a typical procedure, $1 \mathrm{mM}$ stock solution of compound 2 was diluted in HEPES buffer $(10 \mathrm{mM}, \mathrm{pH}=7.4)$ to obtain $100 \mu \mathrm{M}$ solution of 2 . The chromatograms were recorded by monitoring the absorbance at $254 \mathrm{~nm}$. The chromatograms of different amounts of 2 were recorded with the specified method, and the amount of substance and peak area of $\mathbf{2}$ were fitted linearly. The standard curves of compounds 2-G1, 2-G2, 2-G4, 3, 4, $\mathbf{5 , 6}$ and $\mathbf{7}$ were respectively obtained by the same method.

The solution containing $2(100 \mu \mathrm{M})$ was irradiated with OmniCure S1500 LED UV $\left(365 \mathrm{~nm}, 85 \mathrm{~mW} / \mathrm{cm}^{2}\right)$ for different time and the chromatograms of $30 \mathrm{uL}$ were recorded, respectively. According to the standard curve, the relationship between the amount of decomposition of $\mathbf{2}$ and irradiation time was plotted. The curves of compounds $2-\mathrm{G} 1, \mathbf{2 i}, \mathbf{4 i}, \mathbf{3}, \mathbf{4}, \mathbf{5}, \mathbf{6}$ and $\mathbf{7}$ were respectively obtained by the same method.

Agilent's Poroshell 120 EC-C18 $(3 \times 50 \mathrm{~mm}, 2.7$ Micron $)$ column was used for rapid analysis. The flow phase adopts the gradient method set in advance.

\section{Determination of photoreaction quantum yield.}

The determination of quantum yield by chemical actinometer can be calculated by the following formula:

$$
\Phi=\frac{n}{I t X}
$$

Where " $\mathrm{X}$ " is the absorptivity of the radiative light by the sample. " $t$ " is the irradiation time. " $\mathrm{n}$ " is the 
amount of substance reacted. "I" is irradiation intensity. " $\mathrm{n}$ " is determined by HPLC. "I" can be determined according to formula (2)

$$
I=\frac{n_{a c}}{\Phi_{a c} \bullet t \cdot X}
$$

Where $\Phi_{\mathrm{ac}}$ is photoreaction quantum yield of aberchrome. Aberchrome is a chemical actinometer, and its quantum yield under $313-366 \mathrm{~nm}$ irradiation is 0.2 , which is basically independent of solvent and temperature. As we know:

$$
\begin{gathered}
\triangle A=\varepsilon \cdot \triangle \mathrm{c} \cdot \mathrm{d} \\
n_{a c}=V \cdot \triangle c=\frac{V \cdot \triangle A}{\varepsilon \cdot \mathrm{d}}
\end{gathered}
$$

Where "V" is the volume $\left(\mathrm{dm}^{3}\right)$ of aberchrome. " $\varepsilon$ " is molar absorptivity of aberchrome $(\varepsilon=8200$ $\left.\mathrm{dm}^{3} \cdot \mathrm{mol}^{-1} \cdot \mathrm{cm}^{-1}\right)$. " $\triangle \mathrm{A}$ " is variation of absorbance $(494 \mathrm{~nm})$ of aberchrome. "d" is optical length of aberchrome. From formulas (2) and (3), you can get:

$$
\triangle \mathrm{A}=\Phi_{a c} \cdot \varepsilon \cdot d \bullet I \bullet X \bullet t / V
$$

The linear relationship between " $\triangle \mathrm{A}$ " and "t" is plotted, and the slope " $\mathrm{k}$ " can be obtained:

$$
\mathrm{k}=\Phi_{a c} \cdot \varepsilon \cdot d \cdot I \cdot X / V
$$

The light intensity "I" can be calculated by the following formula:

$$
I=\frac{V \cdot k}{\Phi_{a c} \bullet \varepsilon \cdot X \cdot d}
$$

Determination of binding constant of probes with $\mathbf{Z n}^{2+}$. The absorption spectrum of PAR $(210 \mu \mathrm{M})$ in $3.0 \mathrm{~mL}$ of aqueous buffer (40 mM HEPES, $100 \mathrm{mM} \mathrm{KCl}, \mathrm{pH}$ 7.0) was recorded in a quartz cuvette. A $3.0 \mu \mathrm{L}$ of $\mathrm{Zn}^{2+}(10 \mathrm{mM})$ was added and the absorption spectrum was recorded. Next, a $3.0 \mu \mathrm{L}$ of the probe $(2 \mathrm{mM})$ was added and the spectrum was recorded, and this step was repeated ten times. Hypochromic shift at 500 $\mathrm{nm}$ is characteristic of $\mathrm{Zn}^{2+}$ abstraction by probe from $\left[\mathrm{Zn}(\mathrm{PAR})_{2}\right]$ complex. The binding equilibrium and binding constant $\left(\mathrm{K}^{\prime}\right)$ were obtained by solving equations (7).

$$
\begin{gathered}
{\left[\mathrm{Zn}(\mathrm{PAR})_{2}\right]+\mathrm{P} \leftrightarrow \mathrm{ZnP}+2 \mathrm{PAR}} \\
\frac{[\mathrm{ZnP}][\mathrm{PAR}]^{2}}{\left[\mathrm{Zn}(\mathrm{PAR})_{2}\right][P]}=\frac{K^{\prime}}{\beta^{\prime}[P A R]}
\end{gathered}
$$

Where $\mathrm{P}=\mathbf{2}, \mathbf{3}, \mathbf{5}, \mathbf{6}, \beta_{\mathrm{PAR}}^{\prime}=2.2 \times 10^{12} \mathrm{M}^{-1}$.

Computational details. To better understand the photoreaction mechanism, we typically performed quantum chemistry (QM) calculations to study the reaction pathway of 2-G1 to 2-G2/2-G3. Gaussian 16 package $^{7}$ was used to all calculations. DFT and TD-DFT ${ }^{8-9}$ were applied to the ground state (GS) and excited state (ES), respectively. B3LYP ${ }^{10-11}$ global hybrid exchange correlation functional was applied in conjunction with the $6-311++G(d, p)$ basis set. This functional has been successfully used to describe the ES reaction for the similar organic compound. And previous studies have discussed its accuracy in describing structures, thermochemistry and energetics of GS and ES. The implicit Polarizable Continuum Model (PCM) ${ }^{12}$ of water was included in all computations to simulate experimental environment. Structural optimizations were first performed for the reactants and products. For all TD-DFT calculations at least three excited states were computed. Other specific calculations are stated in the results.

According to the results of QM calculations, the reaction from 2-G1 to 2-G2/2-G3 can carry out via two steps. Transition state search calculations were first carried out in S1 excited state to find a possible 
transition state structure for the possible elementary reactions of 2-G1* - TS2 using TS method. The accurate transition state was verified via IRC analysis, and lead to the formation of reactant $(2-\mathrm{G} 1 *)$ and product (TS2). In this step (2-G1* - TS2), the reactant is excited by the light and then a $\mathrm{H}$ is transferred from $\mathrm{N}$ to $\mathrm{C}$, as shown in Figure S15. This process is proceeded via an excited transition state and has to across an activation barrier of about $50 \mathrm{kcal} / \mathrm{mol}$, which followed by an exothermic reaction energy of $36 \mathrm{kcal} / \mathrm{mol}$ (Figure S16). In the second step, the reaction from TS2 to $2-\mathrm{G} 2 / \mathbf{2}-\mathrm{G} 3$ was performed by scanning the C-C bond breakdown process in ground state. As shown in Figure S15, the final products 2-G2 and 2-G3 are indeed generated from the de-excitation product of $2-\mathrm{G} 1 *$. This breakdown is thoroughly spontaneous and simultaneously releasing $35 \mathrm{kcal} / \mathrm{mol}$ of heat (Figure S17). The coordinates of their optimal configurations are provided in Table S2-S6. And it should be noted that, due to the completely exothermicity, the second step of reaction may be so fast that we do not capture the intermediate product of TS2.

$\mathrm{Zn}^{2+}$ release studies using the fluorescent probe R-1. R-1 solutions $(1 \mathrm{mM})$ were prepared in $\mathrm{CH}_{3} \mathrm{CN}$. After the addition of different amounts of $\mathrm{Zn}^{2+}(0,1,2,3,4,5,6,7,8,9,10 \mu \mathrm{M})$, the emission spectra of R-1 $(10 \mu \mathrm{M})$ was recorded respectively with excitation at $315 \mathrm{~nm}$ in HEPES buffer $(10 \mathrm{mM}, \mathrm{pH}=7.4)$. The solution containing R-1 $(10 \mu \mathrm{M})$ and $\mathbf{5}-\mathrm{Zn}^{2+}(10 \mu \mathrm{M})$ was irradiated with LED UV $\left(365 \mathrm{~nm}, 85 \mathrm{~mW} / \mathrm{cm}^{2}\right)$ for $0,20,40,60,80,100,120 \mathrm{~s}$ and the spectrum was recorded, respectively. The changes of emission at $497 \mathrm{~nm}$ were plotted over time.

The deactivation of carbonic anhydrase and determination of $\mathrm{Zn}^{2+}$. Preparation of zinc ion chelating buffer (dialysate): 2,6-Pyridinedicarboxylic acid $(6.25 \mathrm{~g}, 0.0375 \mathrm{~mol})$ was dissolved in $450 \mathrm{~mL}$ deionized water, and sodium dihydrogen phosphate $(12 \mathrm{~g}, 0.1 \mathrm{~mol})$ was added. Adjust the solution to $\mathrm{pH}=7.4$ with sodium hydroxide $(1 \mathrm{~mol} / \mathrm{L})$ and fix the volume of the solution to $500 \mathrm{~mL}$ with deionized water.

The deactivation of carbonic anhydrase: Carbonic anhydrase was dissolved in dialyzed bag with deionized water of $5 \mathrm{~mL}$. And put it in the prepared dialysate and stir for 48 hours. Then replace the dialysate with deionized water and continue dialysis for 24 hours. This step is repeated three times. Finally, the deactivation of carbonic anhydrase (deCA) solution (about $5 \mathrm{~mL}$ ) was obtained.

The absorption of carbonic anhydrase $(15 \mu \mathrm{L})$ at $400 \mathrm{~nm}$ with different amounts of zinc ion $(1 \mathrm{mM}, 0$ $\mu \mathrm{L}, 5 \mu \mathrm{L}, 10 \mu \mathrm{L}$ and $15 \mu \mathrm{L})$ was recorded from $0 \mathrm{~s}$ to $1200 \mathrm{~s}$ with using NPA $(125 \mu \mathrm{M})$ as substrate in HEPES buffer (10 mM, pH 7.4). The standard curve between absorption intensity and zinc ion concentration is fitted.

The absorption $(400 \mathrm{~nm})$ changes of NPA $(125 \mu \mathrm{M})$ within $1200 \mathrm{~s}$ were recorded as blank control test. The absorption $(400 \mathrm{~nm})$ changes of NPA $(125 \mu \mathrm{M})$ and deCA $(15 \mu \mathrm{L})$ within $1200 \mathrm{~s}$ were recorded as negative control test. The absorption $(400 \mathrm{~nm})$ changes of NPA $(125 \mu \mathrm{M})$, deCA $(15 \mu \mathrm{L})$ and $\mathrm{Zn}^{2+}(5 \mu \mathrm{M})$ within $1200 \mathrm{~s}$ were recorded as positive control test. Then the absorption $(400 \mathrm{~nm})$ changes of deCA $(15 \mu \mathrm{L})$ within $1200 \mathrm{~s}$ were recorded with using NPA $(125 \mu \mathrm{M})$ as substrate, when $\mathbf{5}-\mathrm{Zn}^{2+}(5 \mu \mathrm{M})$ before and after irradiation $\left(365 \mathrm{~nm}, 85 \mathrm{~mW} / \mathrm{cm}^{2}\right)$ was added respectively. And the corresponding fluorescence spectrum $\left(\lambda_{\mathrm{ex}}\right.$ $=450 \mathrm{~nm}$, slits: $5 \mathrm{~nm} / 5 \mathrm{~nm}$ ) of the solution at $1200 \mathrm{~s}$ was also recorded.

Cell viability assay. The Cell Counting Kit-8 (CCK-8) assay was used evaluate the cytotoxicity of compounds 5, 6 and 7. Briefly, the human embryonic kidney 293 (HEK 293) cells were seeded at $10^{4}$ cells a density of per well in a 96 well plate and incubated in the culture medium for $24 \mathrm{~h}$ in a humidified atmosphere of $5 \% \mathrm{CO}_{2}$ at $37{ }^{\circ} \mathrm{C}$. Then, the cells were treated with various concentration of $\mathbf{5}-\mathrm{Zn}^{2+}$. In another set of experiments, the cells were incubated with compound $\mathbf{5}-\mathrm{Zn}^{2+}$ for $30 \mathrm{~min}$ and continued to be irradiated with $365 \mathrm{~nm}$ light at a power of $85 \mathrm{~mW} / \mathrm{cm}^{2}$ for $3 \mathrm{~min}$. The control group cell was treatments without laser irradiation. After all cells were further incubated for 12 hours, $10 \mu \mathrm{L}$ CCK-8 solution was added to each well 
and the cell were incubated for another $2 \mathrm{~h}$. The was then determined by measuring absorbance at $450 \mathrm{~nm}$ with a microplate reader (synergy H1, BioTek), and the cell viability was obtained by the following equation: Cell viability $(\%)=[\mathrm{A}($ treated $)-\mathrm{A}($ blank $)] /[\mathrm{A}($ control) $-\mathrm{A}($ blank $)] \times 100 \%$.

A (treated): absorbance of wells with cells, CCK-8 solution and compound 5- $\mathrm{Zn}^{2+}$

A (blank): absorbance of wells with medium and CCK-8 solution without cells

A (control): absorbance of a well with cells, CCK-8 solution without any other reagents

The toxicity of $\mathbf{6}-\mathrm{Zn}^{2+}$ to Hela cells was tested using the same method, and the toxicity of compound $\mathbf{7}$ to primary mouse cardiomyocytes was tested using the same method.

NMDARs experiments. HEK 293T cells were transiently transfected with cDNA constructs of GluN1-IRES-mCherry and GluN2A-IRES-EGFP in pCAGGS vectors at a ratio of 1:1 using lipofectamine 2000 reagent (Invitrogen). The cells were then incubated overnight with NMDARs antagonists D-AP5 (D-2-amino-5-phosphonovalerate, $200 \mathrm{mM})$ and 5,7-dichlorokynurenic acid $(200 \mathrm{mM})$. Whole-cell NMDARs currents were recorded using an Axopatch 700B amplifier from fluorescence positive HEK cells. The recording chamber was continuously perfused with extracellular solution composed of (in mmol/L) 140 $\mathrm{NaCl}, 2.5 \mathrm{KCl}, 2 \mathrm{CaCl}_{2}, 10$ HEPES, pH 7.4. Patch pipettes with resistances of $3-5 \mathrm{M} \Omega$ were filled with internal solution containing $125 \mathrm{mM} \mathrm{KF}, 33 \mathrm{mM} \mathrm{KOH}, 2 \mathrm{mM} \mathrm{MgCl} 2,1 \mathrm{mM} \mathrm{CaCl}, 11 \mathrm{mM}$ EGTA, $10 \mathrm{mM}$ HEPES, $\mathrm{pH}$ 7.2. After formation of whole-cell configuration, the cells were carefully lifted up from the culture dishes. Holding at $-70 \mathrm{mV}$, the NMDAR currents were recorded by rapid application of the external solution containing $1 \mathrm{mM}$ glutamate and $10 \mu \mathrm{mol} / \mathrm{L}$ glycine with or without complex $5-\mathrm{Zn}^{2+}$ for $5 \mathrm{~ms}$ with a theta glass pipette mounted on a piezoelectric bimorph at a frequency of $0.1 \mathrm{~Hz} .{ }^{13}$ The baseline currents were recorded for at least 3 times. Then $\mathrm{Zn}^{2+}$ was released from complex 5- $\mathrm{Zn}^{2+}$ by $h v$ application (365 nm, 85 $\mathrm{mW} / \mathrm{cm}^{2}$ ) for over $30 \mathrm{~s}$ and NMDAR currents was measured.

HeLa cells experiments. HeLa cells (Cobioer Biosciences Company, Nanjing, China) were grown in culture media containing 10\% (V/V) fetal bovine serum (FBS, Gibco), $100 \mathrm{mg} / \mathrm{mL}$ streptomycin (Gibco), $100 \mathrm{U} / \mathrm{mL}$ penicillin (Gibco) and DMEM (Gibco) with $5 \% \mathrm{CO}_{2}$ at $37^{\circ} \mathrm{C}$. After respectively transferring to petri dishes, cells were incubated at $37{ }^{\circ} \mathrm{C}$ for $24 \mathrm{~h}$. Whereafter, HeLa cells were treated with compound 6- $\mathrm{Zn}^{2+}(10 \mu \mathrm{M})$ and DND99 $(10 \mu \mathrm{M})$ for $30 \mathrm{~min}$. The cells were irradiated with LED UV (365 nm, 85 $\mathrm{mW} / \mathrm{cm}^{2}$ ) for $0,30,90 \mathrm{~s}$ and the cells photograph of the bright field, green channel and red channel were recorded separately by confocal laser scanning microscopy (Leica, TCS sp5 II). HeLa cells were treated with compound 6- $\mathrm{Zn}^{2+}(10 \mu \mathrm{M})$ and R-1 $(10 \mu \mathrm{M})$ for $30 \mathrm{~min}$. The cells were irradiated with LED UV (365 $\mathrm{nm}, 85$ $\mathrm{mW} / \mathrm{cm}^{2}$ ) for $0,10,30,60 \mathrm{~s}$ and the cells photograph of the bright field, green channel and blue channel were recorded separately by microscope (OLYMPUS IX73).

Primary mouse cardiomyocytes experiments. Primary mouse cardiomyocytes were grown in culture media containing 10\% (V/V) fetal bovine serum (FBS, Gibco), $100 \mathrm{mg} / \mathrm{mL}$ streptomycin (Gibco), $100 \mathrm{U} / \mathrm{mL}$ penicillin (Gibco) and DMEM (Gibco) with $5 \% \mathrm{CO}_{2}$ at $37^{\circ} \mathrm{C}$. After respectively transferring to petri dishes, cells were incubated at $37^{\circ} \mathrm{C}$ for $48 \mathrm{~h}$.

Three groups of experiments were respectively carried out in three petri dishes. I. The pulsatile of myocardial cells was monitored and recorded by microscope (Supplementary video i-1). After cardiomyocytes were incubated with ACh $(20 \mu \mathrm{M})$ for 3 minutes, the pulsatile of cardiomyocytes was monitored and recorded again (Supplementary video i-2). Then the cardiomyocytes were irradiated with ultraviolet light for 60 seconds and incubated for 3 minutes, and the pulsatile of cardiomyocytes was monitored and recorded again (Supplementary video i-3). Finally, after adding AChE $(0.024 \mathrm{U} / \mathrm{mL})$ and incubating the cells for three minutes, the pulsatile of cardiomyocytes was monitored and recorded again 
(Supplementary video i-4). II. The pulsatile of myocardial cells was monitored and recorded by microscope (Supplementary video ii-1). After cardiomyocytes were incubated with ACh $(20 \mu \mathrm{M})$ for 3 minutes, the pulsatile of cardiomyocytes was monitored and recorded again (Supplementary video ii-2). Then after adding the compound $7(0.2 \mu \mathrm{M})$ and incubating the cells for 3 minutes, the pulsatile of cardiomyocytes was monitored and recorded again (Supplementary video ii-3). Finally, after adding AChE $(0.024 \mathrm{U} / \mathrm{mL})$ and incubating the cells for three minutes, the pulsatile of cardiomyocytes was monitored and recorded again (Supplementary video ii-4). III. The pulsatile of myocardial cells was monitored and recorded by microscope (Supplementary video iii-1). After adding ACh $(20 \mu \mathrm{M})$ and incubating the cells for three minutes, the pulsatile of cardiomyocytes was monitored and recorded again (Sup-plementary video iii-2). After adding the compound $7(0.2 \mu \mathrm{M})$, the cells were irradiated with ultraviolet light for 60 seconds and incubated for 3 minutes. The pulsatile of cardiomyocytes was monitored and recorded (Supplementary video iii-3). Then after adding AChE $(0.024 \mathrm{U} / \mathrm{mL})$ and incubating the cells for three minutes, the pulsatile of cardiomyocytes was monitored and recorded again (Supplementary video iii-4). Finally, after adding AChE $(0.048 \mathrm{U} / \mathrm{mL})$ again and incubating the cells for three minutes, the pulsatile of cardiomyocytes were monitored and recorded again (Supplementary video iii-5).

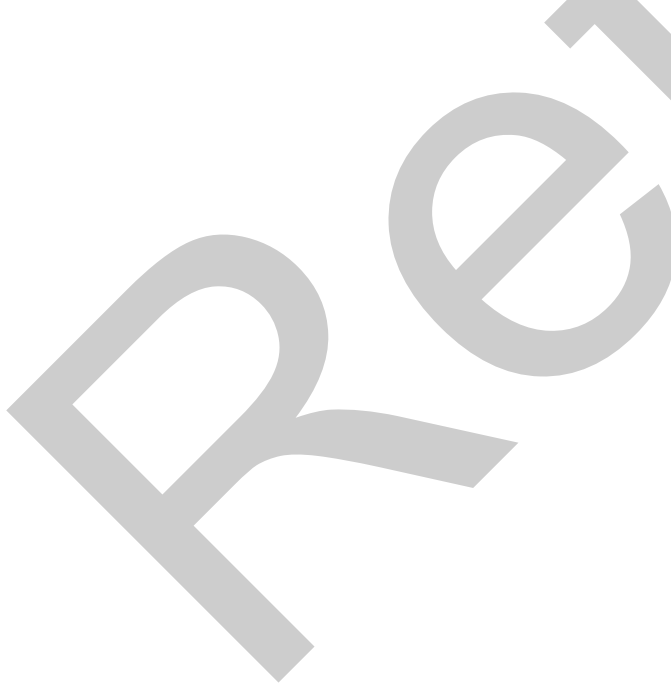




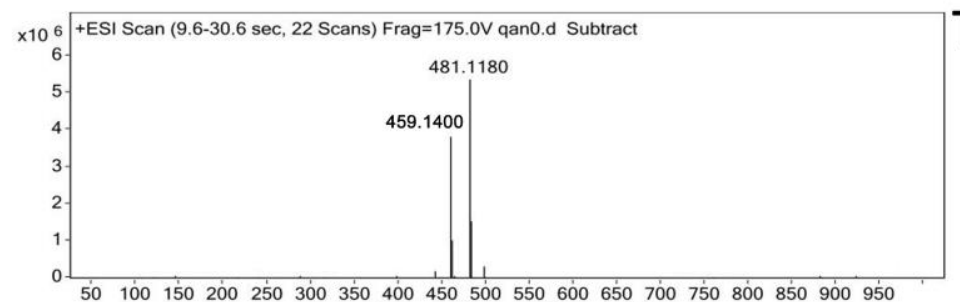

Time

$0 \mathrm{~s}$

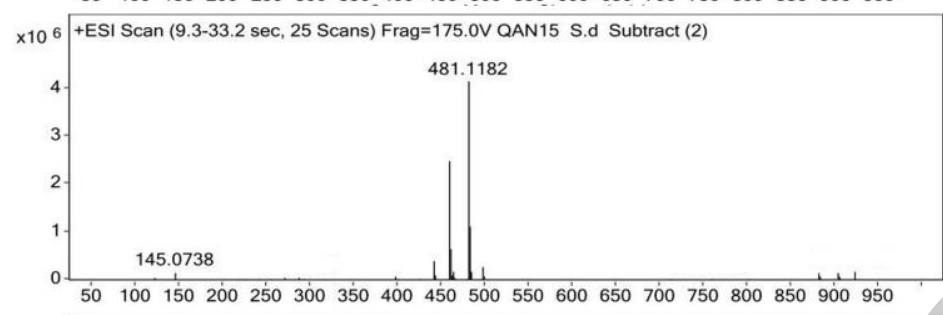

$15 \mathrm{~s}$
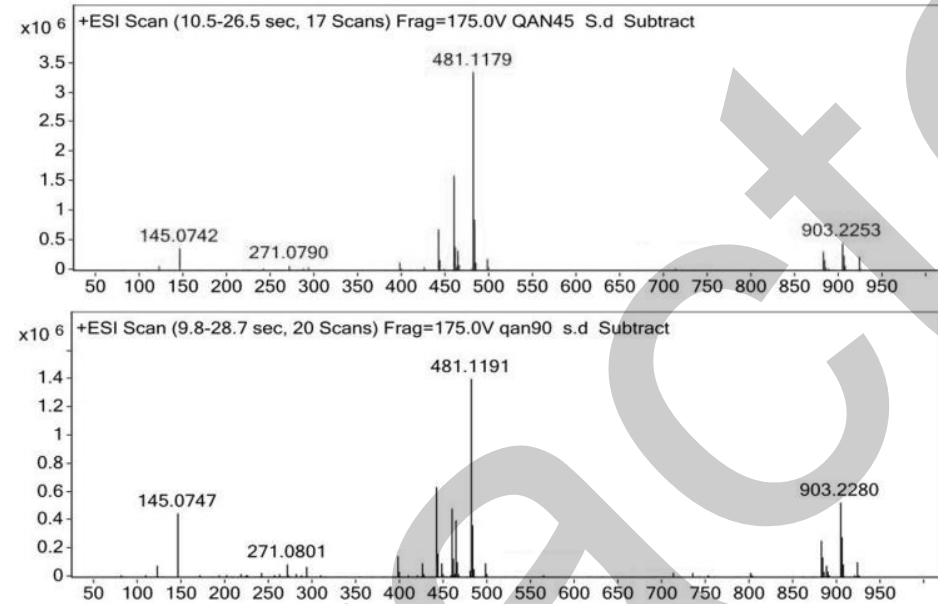

$45 \mathrm{~s}$

25 +ESI Scan (8.7-31.6 sec, 24 Scans) Frag=175.0V qan 150 s.d Subtract

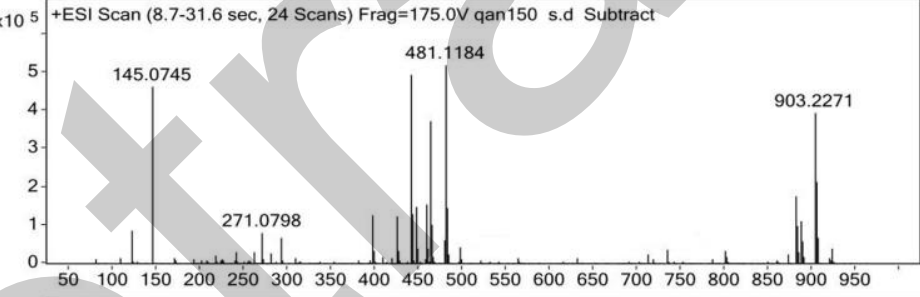

$90 \mathrm{~s}$

$10^{5}$ +ESI Scan (9.0-36.9 sec, 29 Scans) Frag=175.0V qan180 s.d Subtract

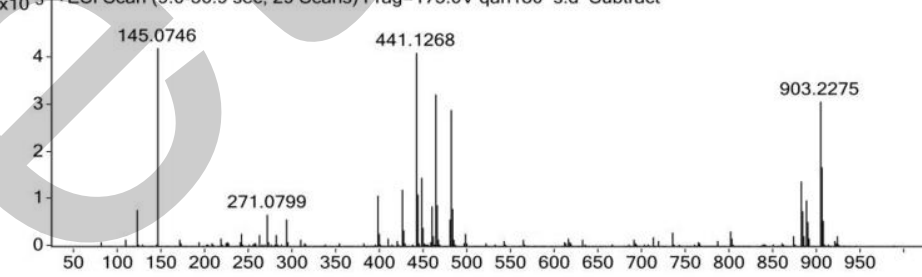

${ }_{5}+$ +ESI Scan (9.3-40.1 sec, 32 Scans) Frag=175.0V QAN270 S.d Subtrac

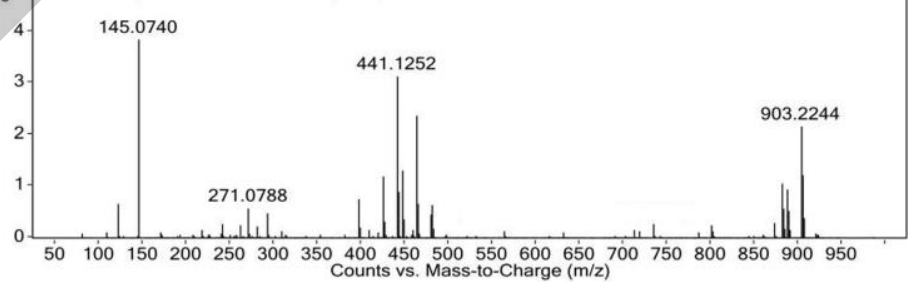

Figure S1. High resolution mass spectrometry of 2 with different irradiation time $(365 \mathrm{~nm}, 85$ $\left.\mathrm{mW} / \mathrm{cm}^{2}\right)$. 


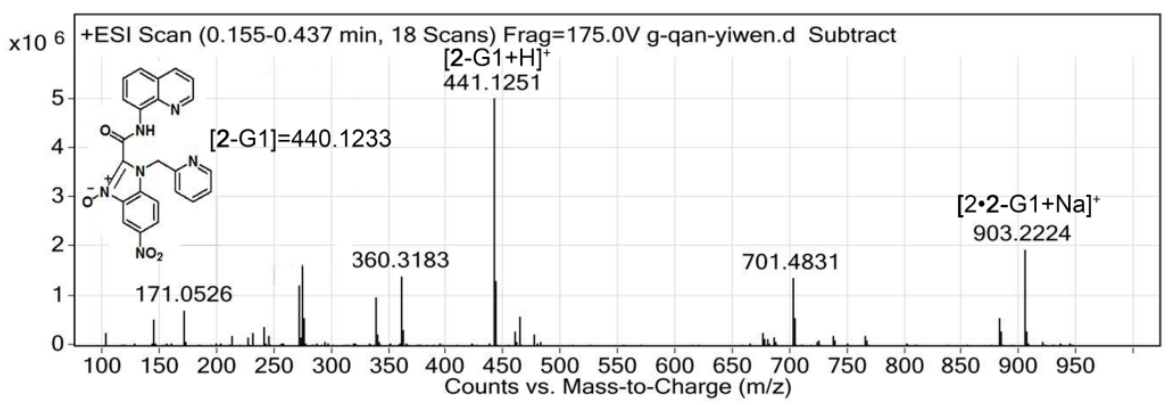

Figure S2. High resolution mass spectrometry of 2-G1.

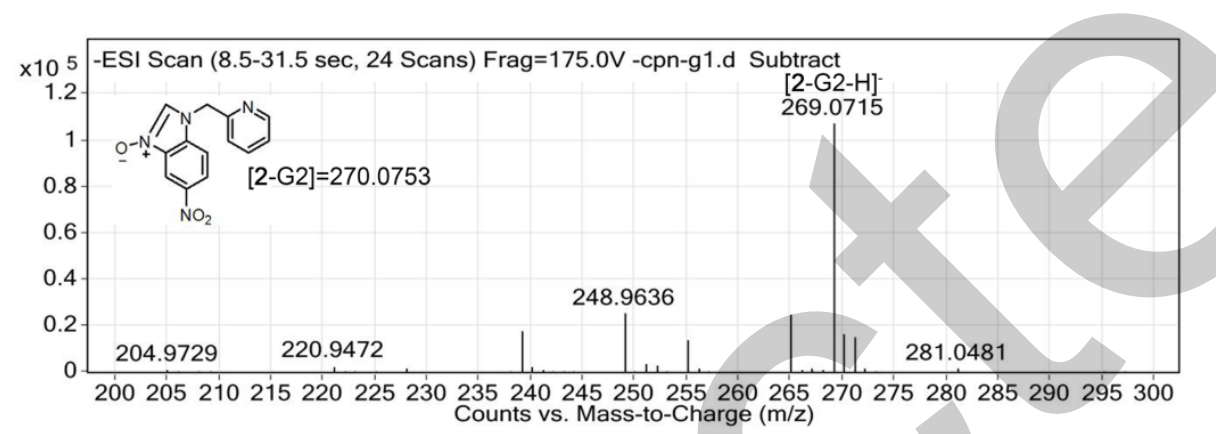

Figure S3. High resolution mass spectrometry of 2-G2.

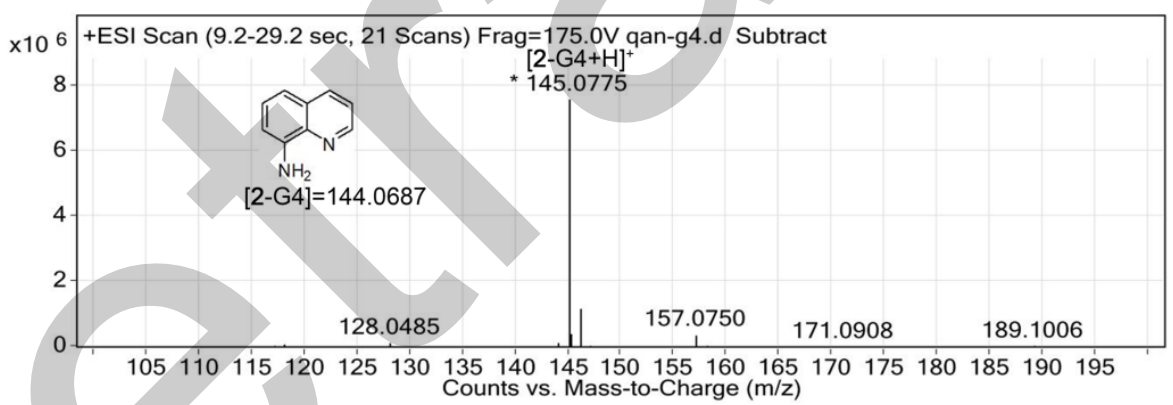

Figure S4. High resolution mass spectrometry of 2-G4. 


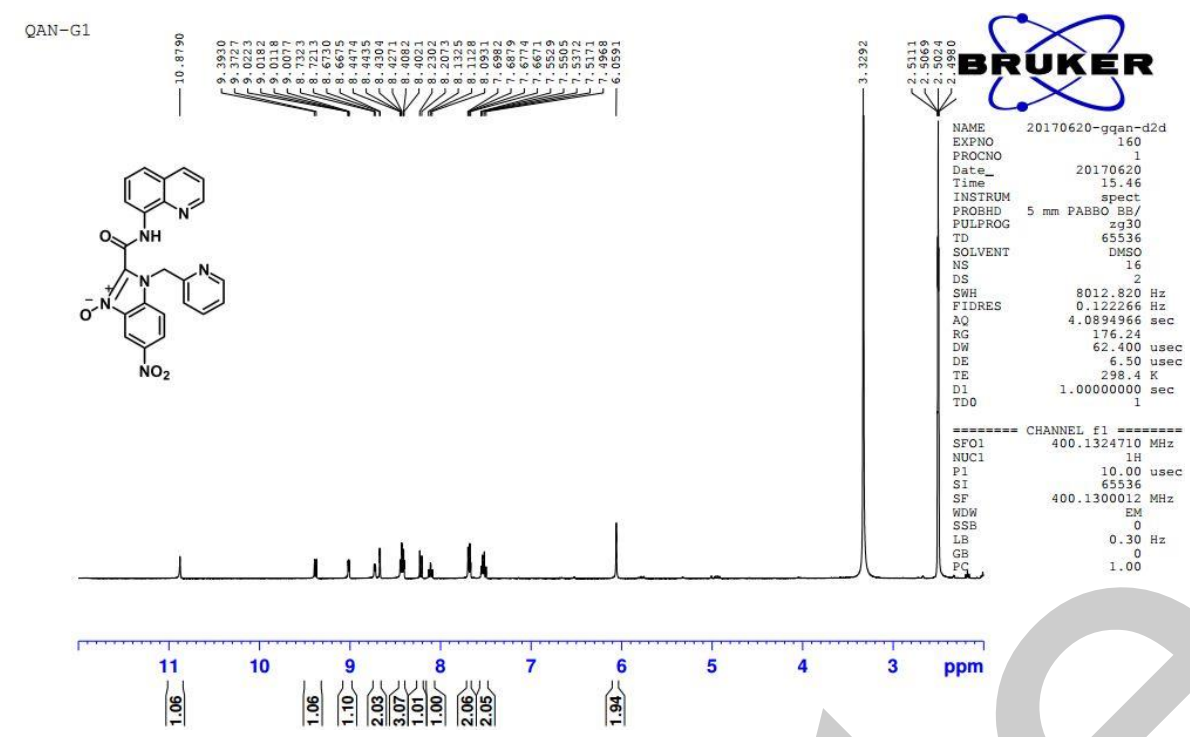

Figure S5. ${ }^{1} \mathrm{H}$ NMR spectrum of 2-G1 in DMSO- $d_{6}$.

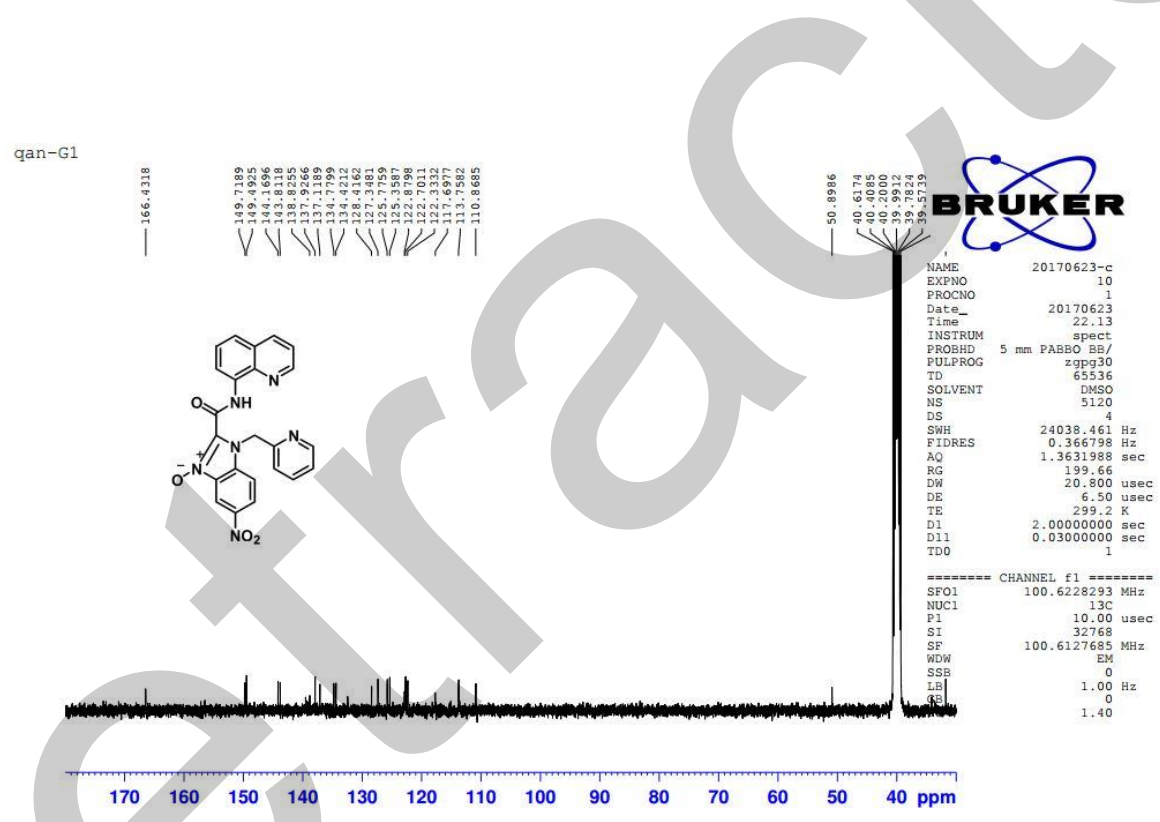

Figure S6. ${ }^{13} \mathrm{C}$ NMR spectrum of 2-G1 in DMSO- $d_{6}$. 


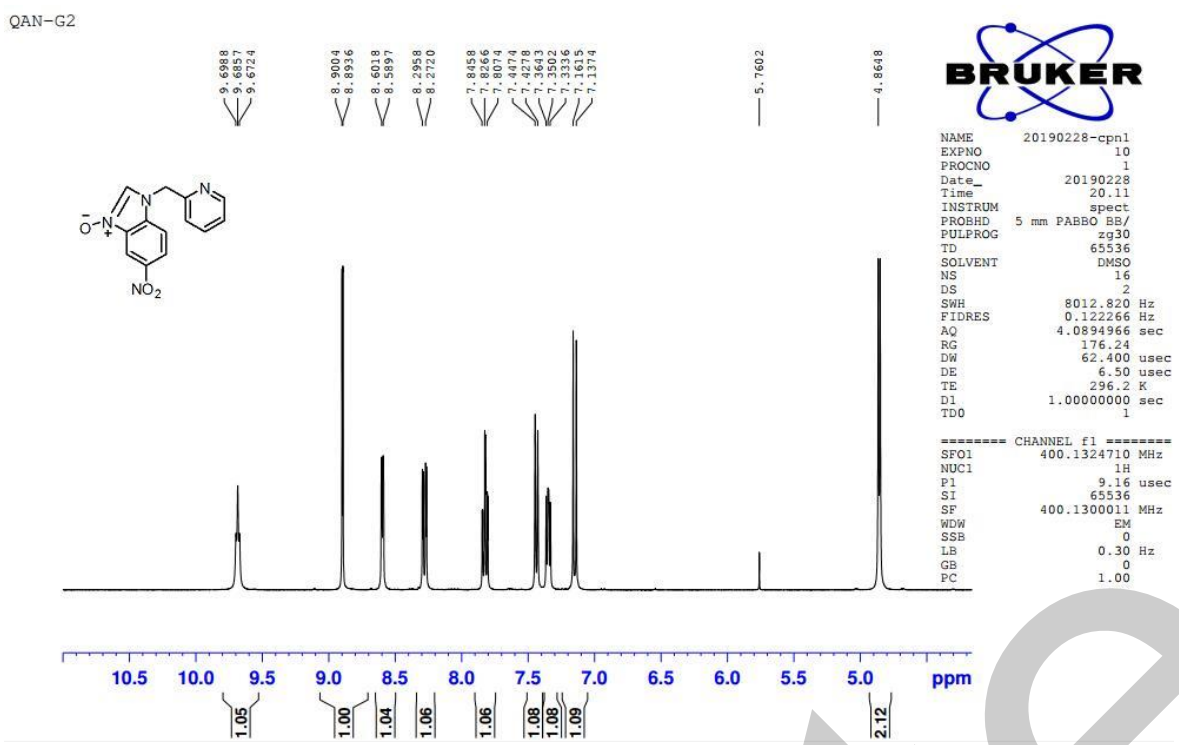

Figure S7. ${ }^{1} \mathrm{H}$ NMR spectrum of 2-G2 in DMSO- $d_{6}$.

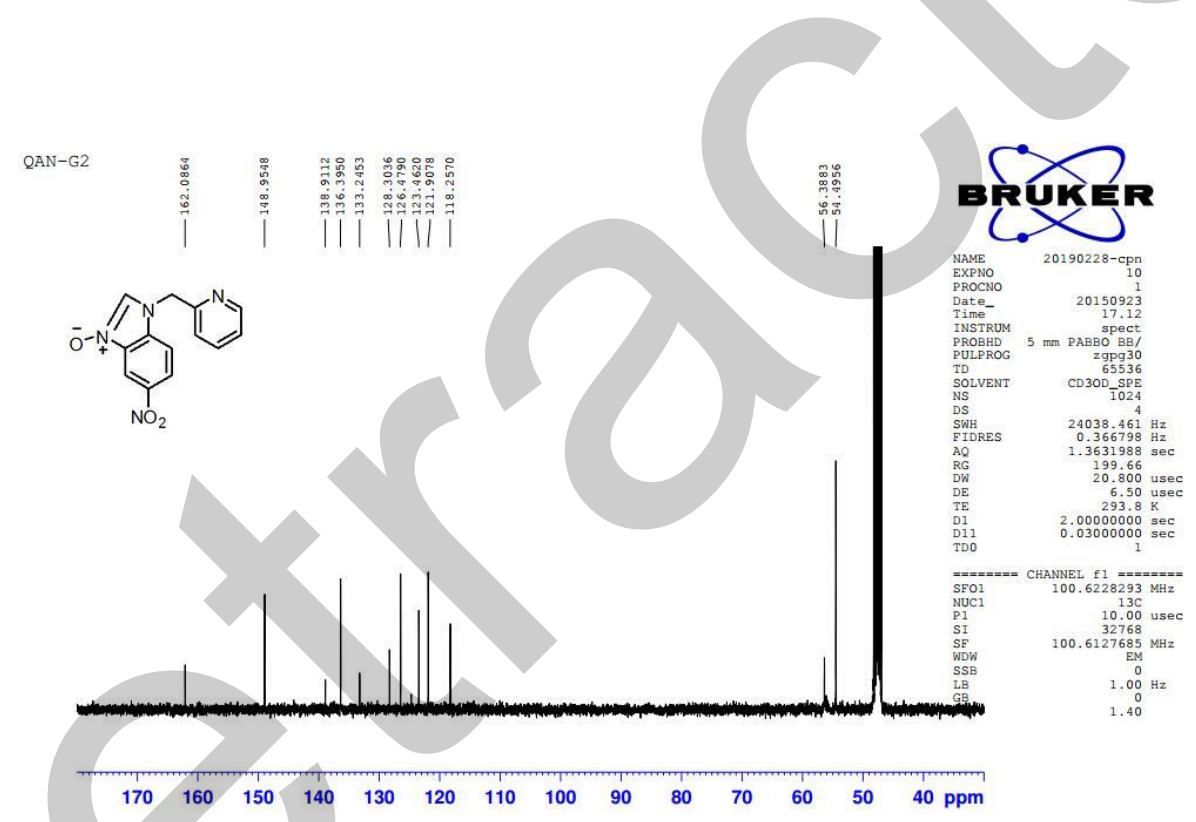

Figure S8. ${ }^{13} \mathrm{C}$ NMR spectrum of 2-G2 in DMSO- $d_{6}$. 


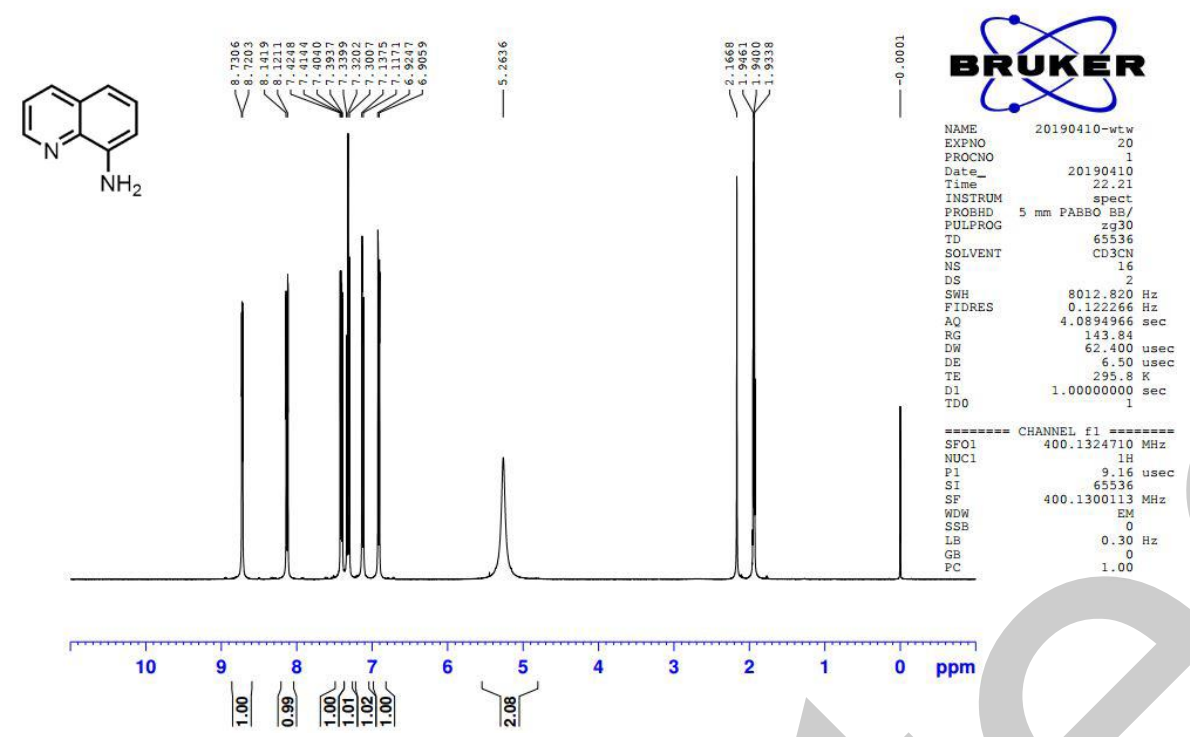

Figure S9. ${ }^{1} \mathrm{H}$ NMR spectrum of $2-\mathrm{G} 4$ in $\mathrm{CD}_{3} \mathrm{CN}$.

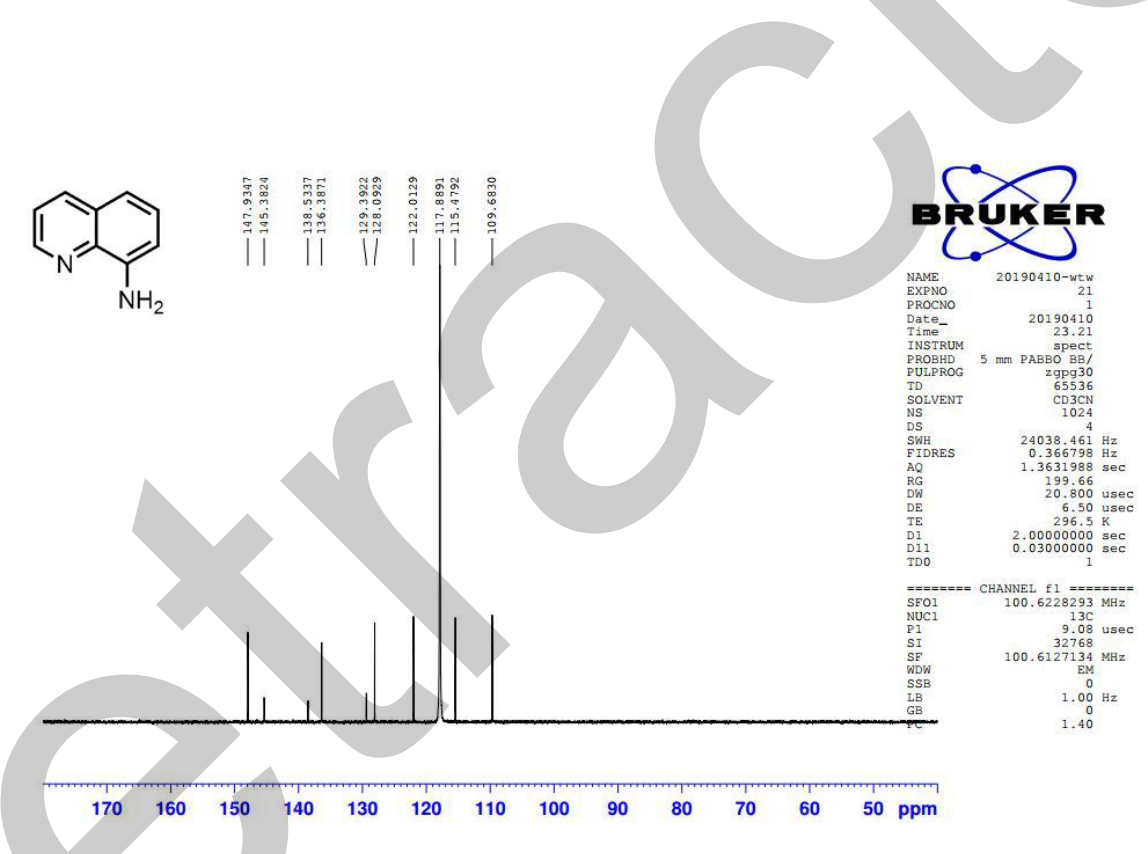

Figure S10. ${ }^{13} \mathrm{C}$ NMR spectrum of $2-\mathrm{G} 4$ in $\mathrm{CD}_{3} \mathrm{CN}$. 

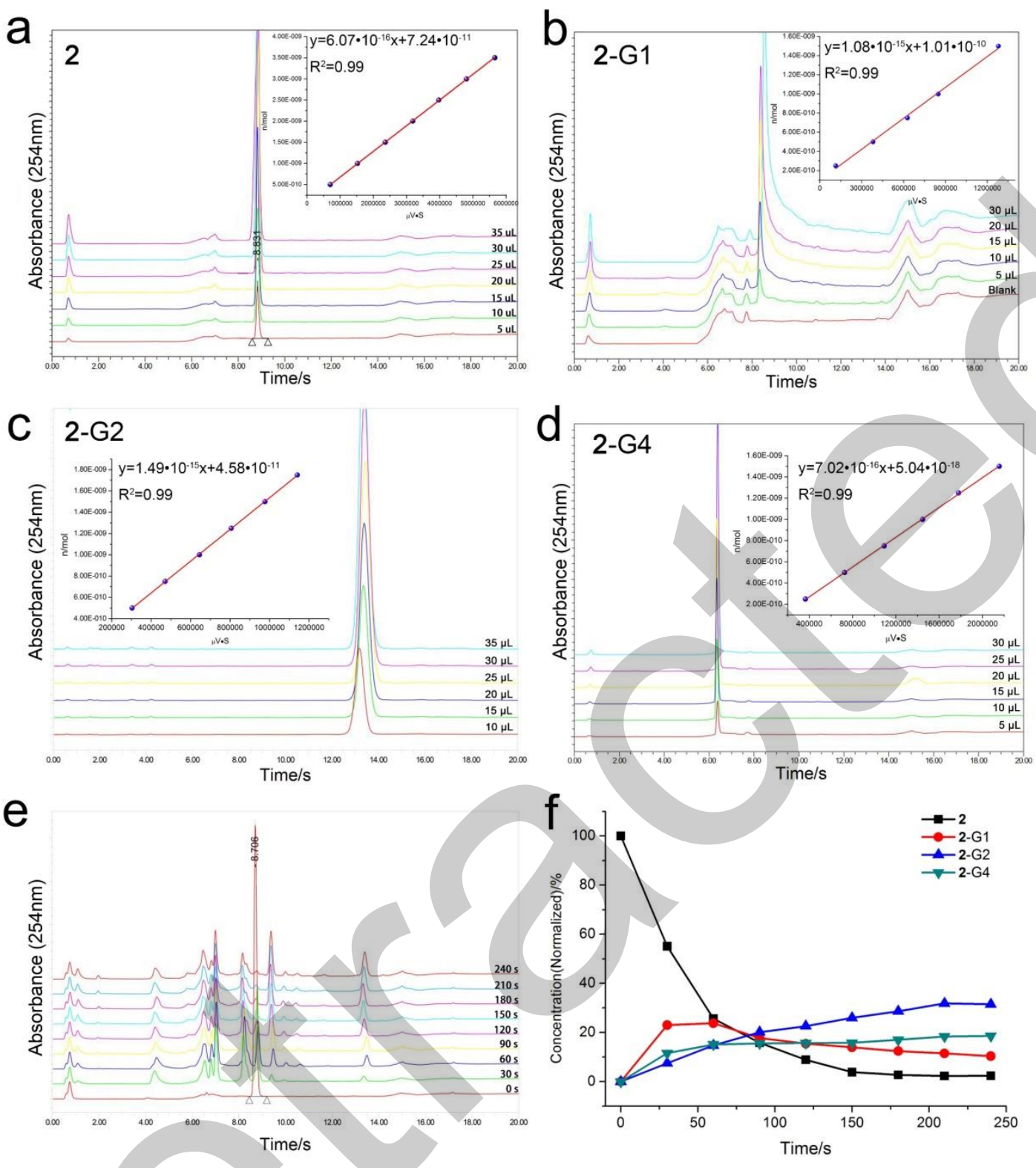

Figure S11. HPLC of $100 \mu \mathrm{mol} / \mathrm{L} 2$ (a), $50 \mu \mathrm{mol} / \mathrm{L} \mathrm{2-G1} \mathrm{(b),} 50 \mu \mathrm{mol} / \mathrm{L} 2-\mathrm{G} 2$ (c) and $50 \mu \mathrm{mol} / \mathrm{L}$ 2-G4 (d) in HEPES buffer $(10 \mathrm{mM}, \mathrm{pH}=7.4)$ with different injection volume; Illustration: the linear relationship between the peak area and the amount of substance. (e) HPLC of $100 \mu \mathrm{mol} / \mathrm{L} 2$ with different irradiation $\left(365 \mathrm{~nm}, 85 \mathrm{~mW} / \mathrm{cm}^{2}\right)$ time in HEPES buffer $(10 \mathrm{mM}, \mathrm{pH}=7.4)$. (f) Time course of photolysis of compound 2 under UV irradiation $\left(365 \mathrm{~nm}, 85 \mathrm{~mW} / \mathrm{cm}^{2}\right)$, Concentrations were determined by HPLC and normalized to the baseline. 

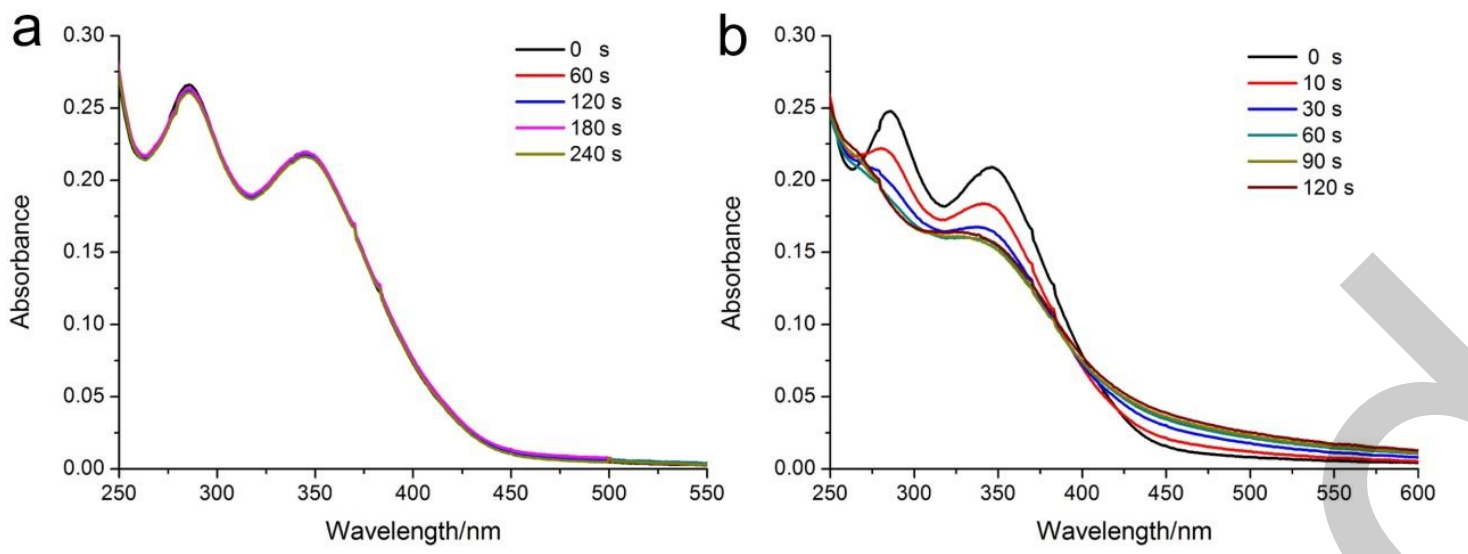

Figure S12. (a) The absorption spectra of 2-G1 $(10 \mu \mathrm{M})$ with different detection time in HEPES buffer $(10 \mathrm{mM}, \mathrm{pH}=7.4)$. (b) The absorption spectra of 2-G1 $(10 \mu \mathrm{M})$ with different irradiation times $\left(365 \mathrm{~nm}, 85 \mathrm{~mW} / \mathrm{cm}^{2}\right)$ in HEPES buffer $(10 \mathrm{mM}, \mathrm{pH}=7.4)$.

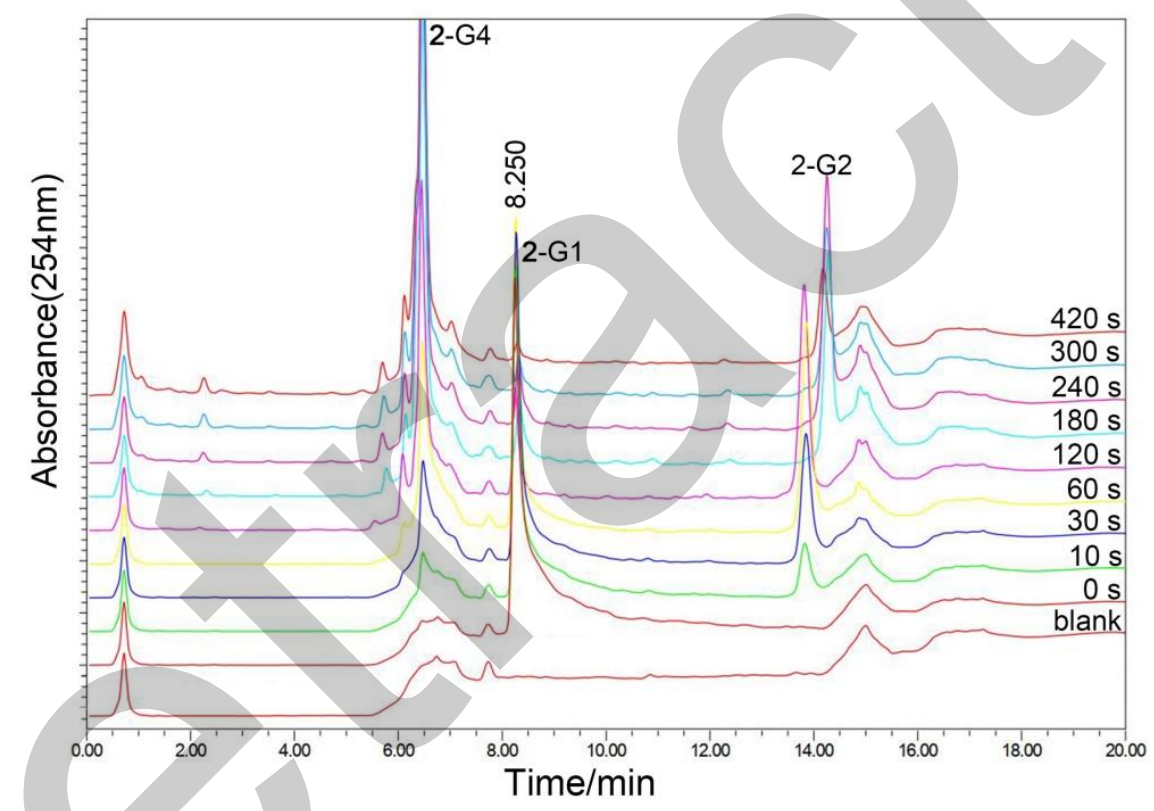

Figure S13. HPLC of $50 \mu \mathrm{mol} / \mathrm{L}$ 2-G1 with different irradiation $\left(365 \mathrm{~nm}, 85 \mathrm{~mW} / \mathrm{cm}^{2}\right)$ time in HEPES buffer (10 mM, pH=7.4). 


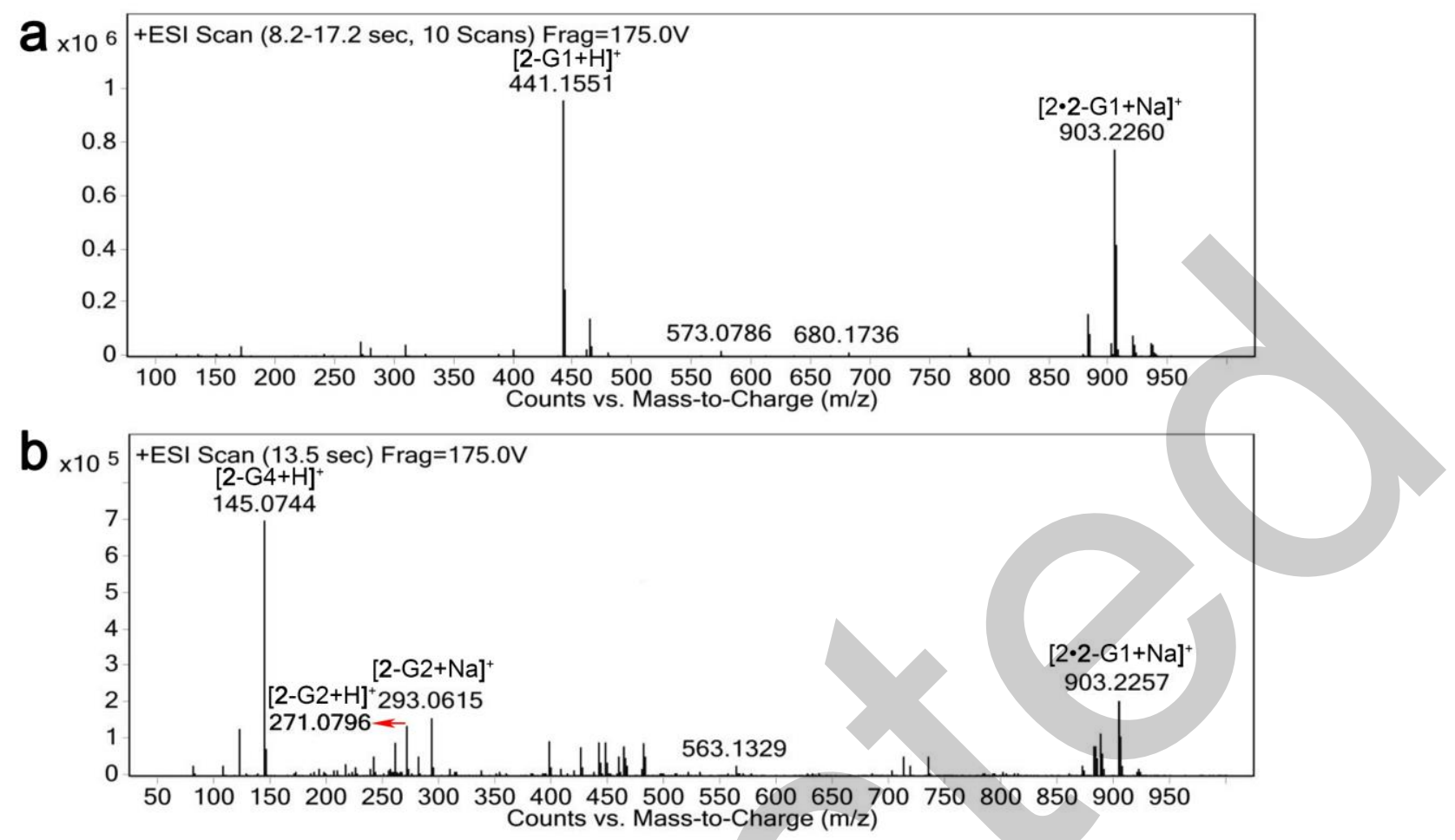

Figure S14. High resolution mass spectrometry of 2-G1 before (a) and after (b) irradiation (365 $\mathrm{nm}, 85 \mathrm{~mW} / \mathrm{cm}^{2}$ ). 

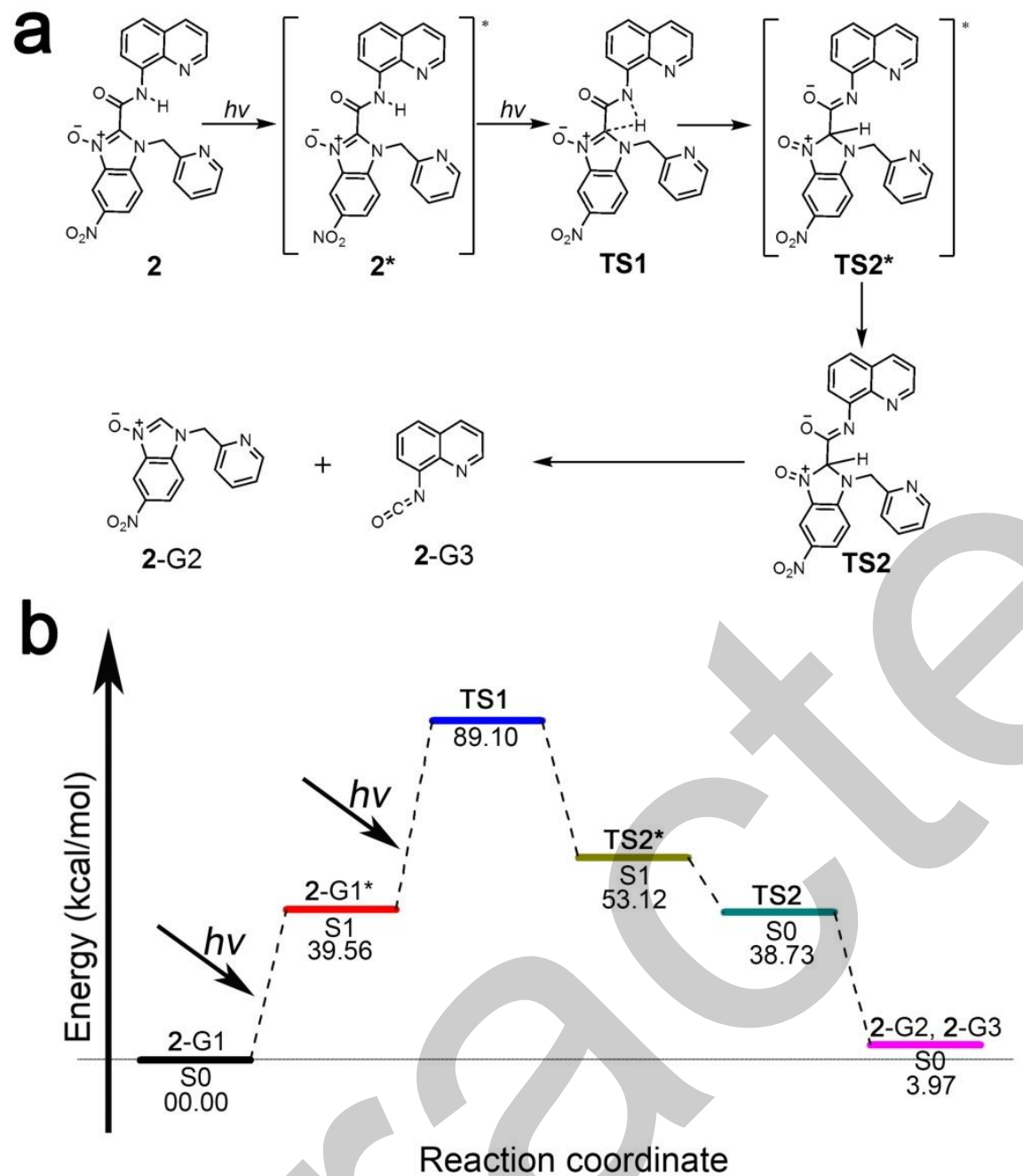

Figure S15. The Reaction path (a) and Potential energy profiles (b) for 2-G1 photodecomposition to produce 2-G2 and 2-G3. 

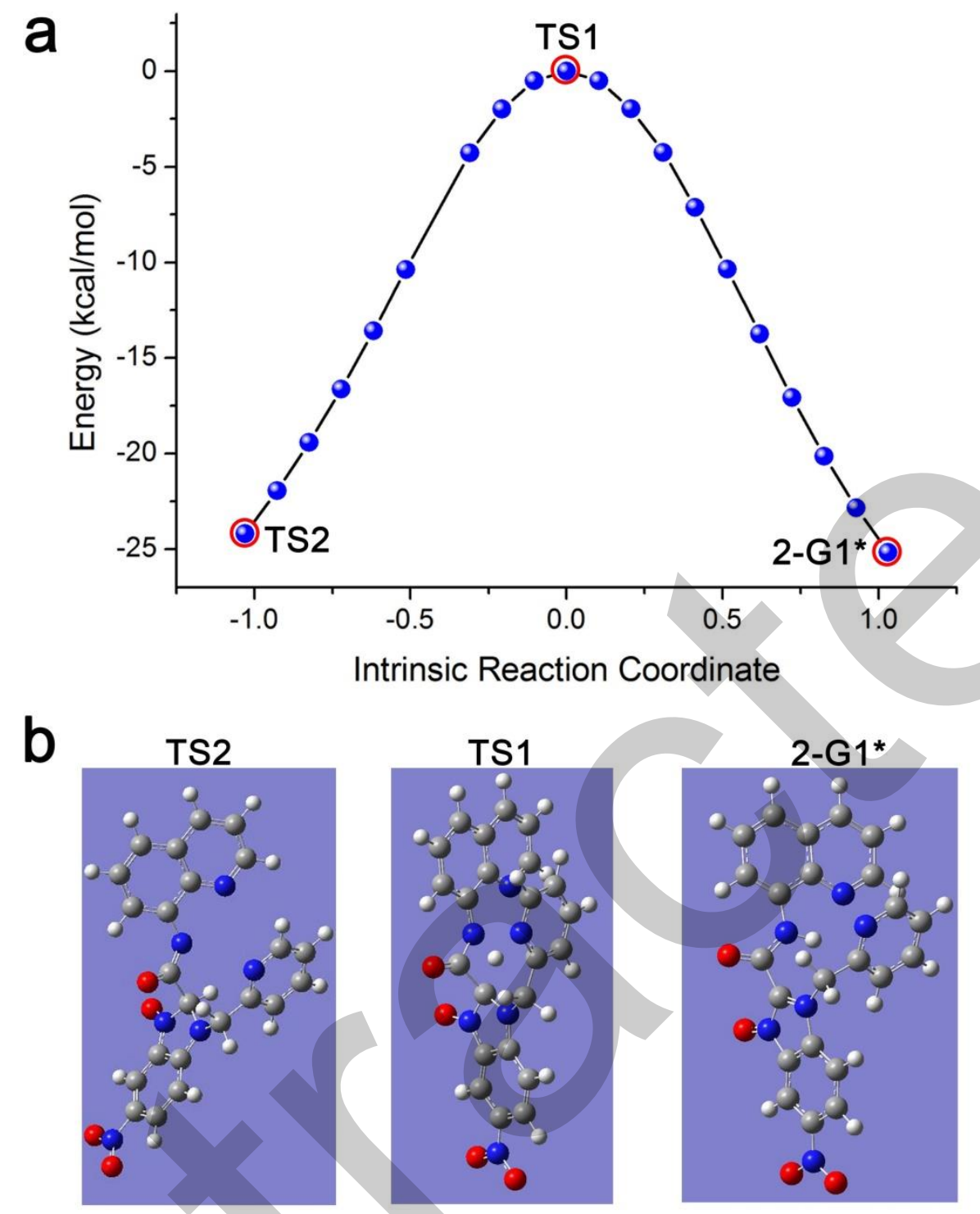

Figure S16. (a) Total energy along IRC from 2-G1* to TS2. (b) The Structure of compounds TS2, TS1, 2-G1*. 


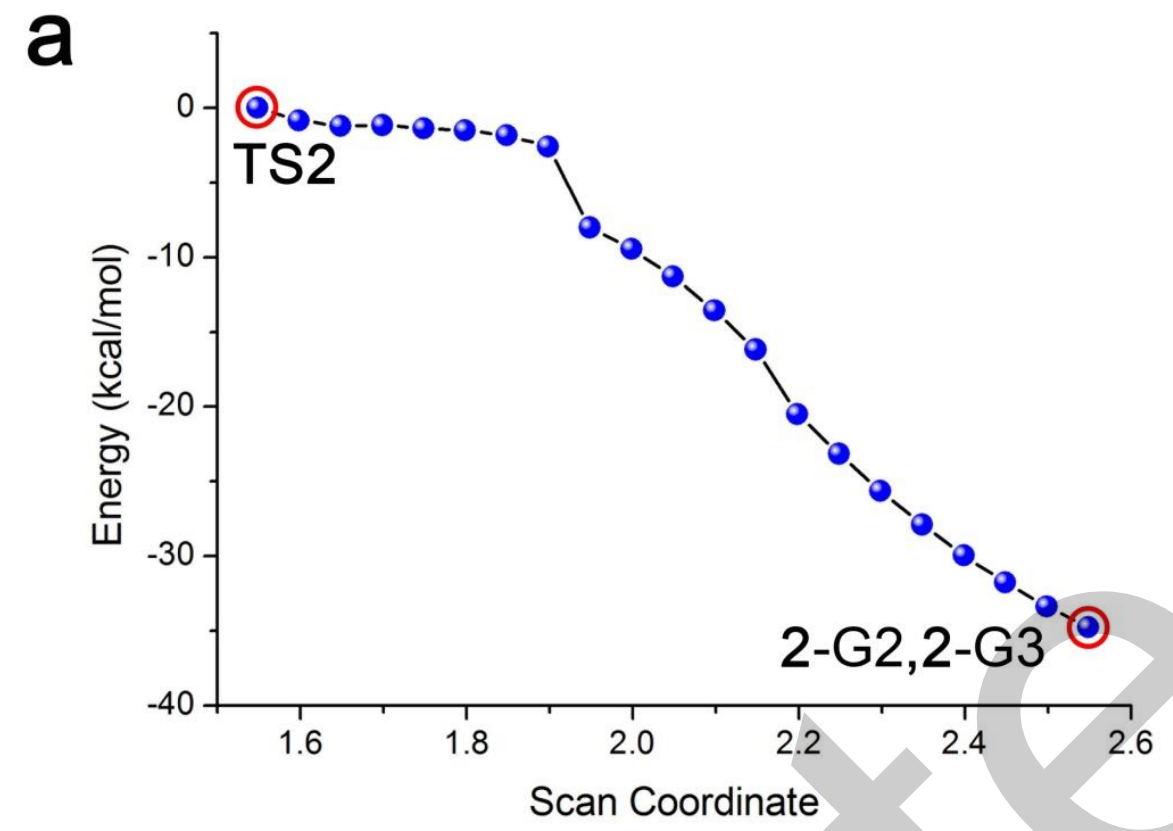

b

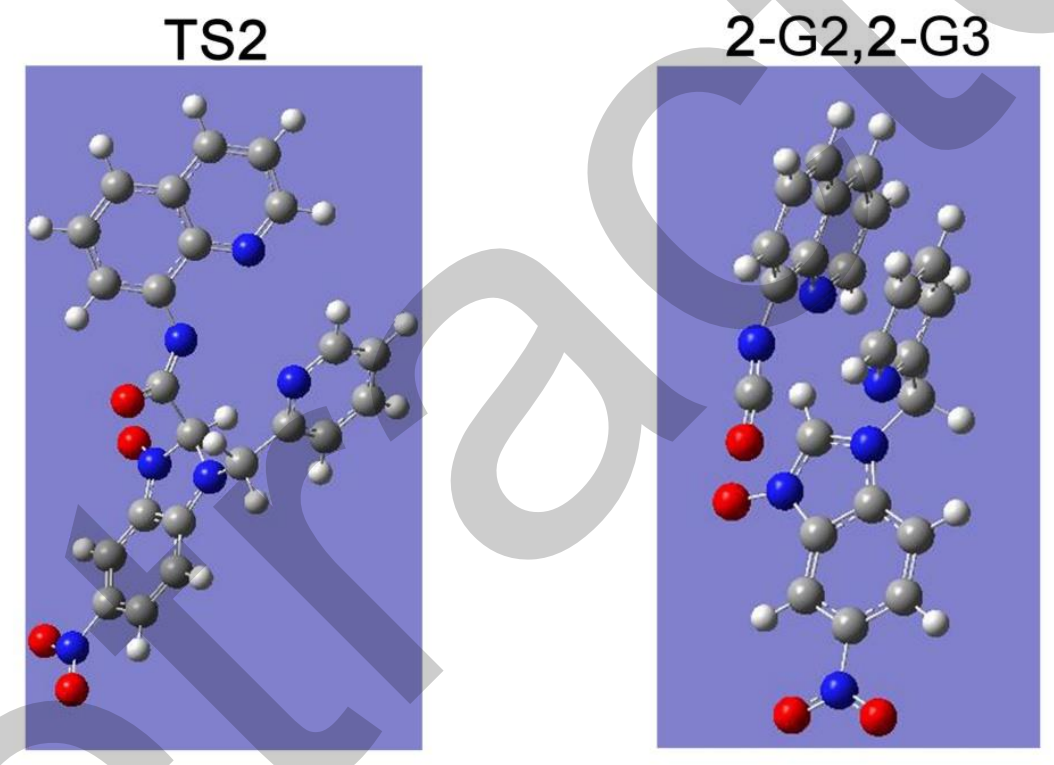

Figure S17. (a) Scan of total energy of TS2 and 2-G2/2-G3. (b) The Structure of compounds TS2, 2-G2, 2-G3. 


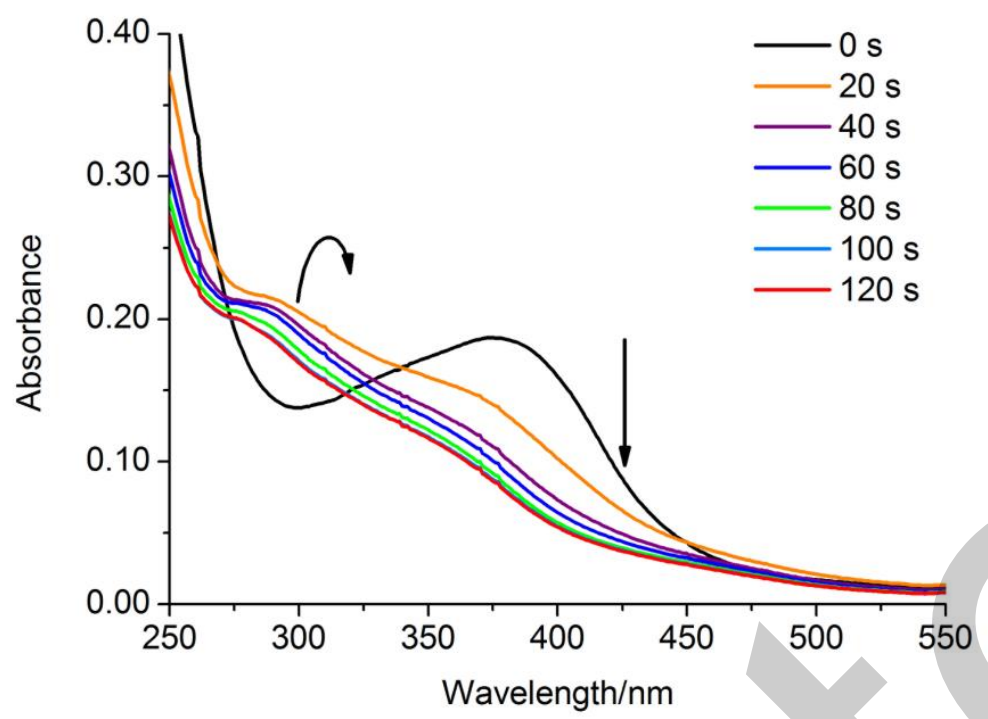

Figure S18.The absorption spectra of $3(10 \mu \mathrm{M})$ with different irradiation times $(365 \mathrm{~nm}, 85$ $\left.\mathrm{mW} / \mathrm{cm}^{2}\right)$ in HEPES buffer (10 $\left.\mathrm{mM}, \mathrm{pH}=7.4\right)$.

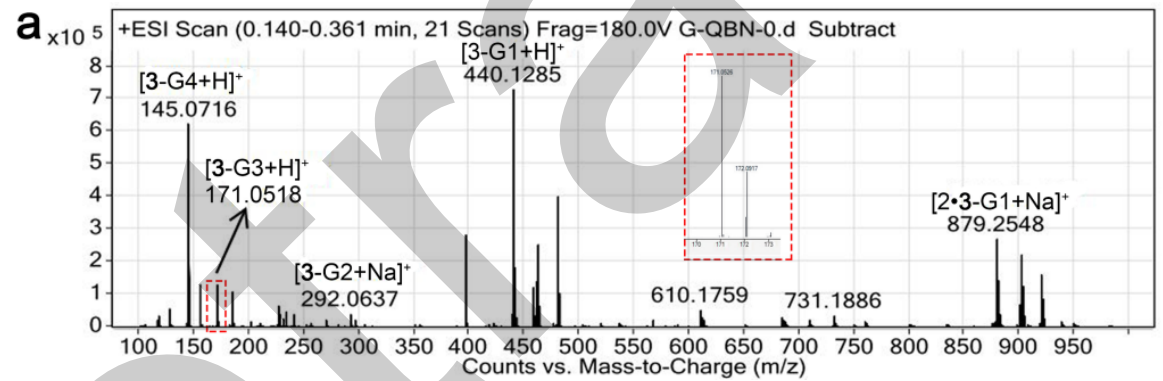

Figure S19. High Resolution Mass Spectrometry (a) and local amplification of the compound 3 after irradiation $\left(365 \mathrm{~nm}, 85 \mathrm{~mW} / \mathrm{cm}^{2}\right)$.

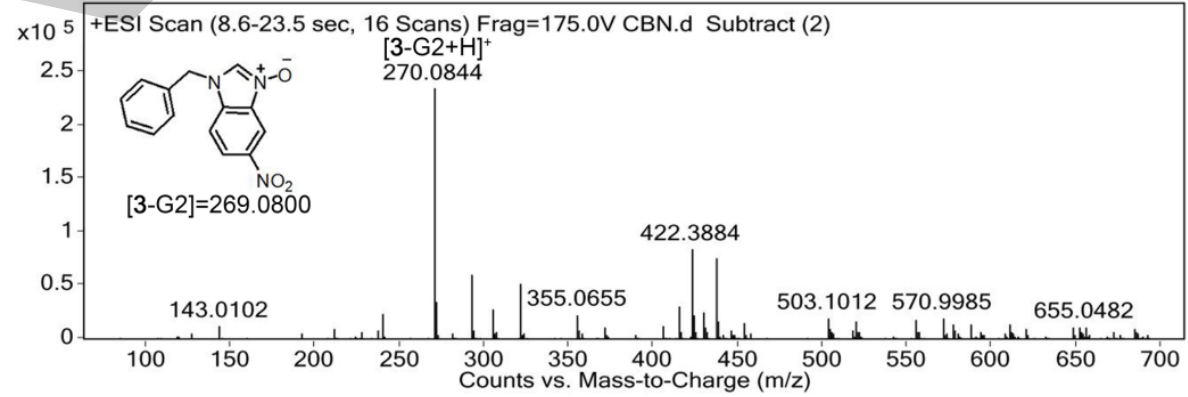

Figure S20. High resolution mass spectrometry of 3-G2. 


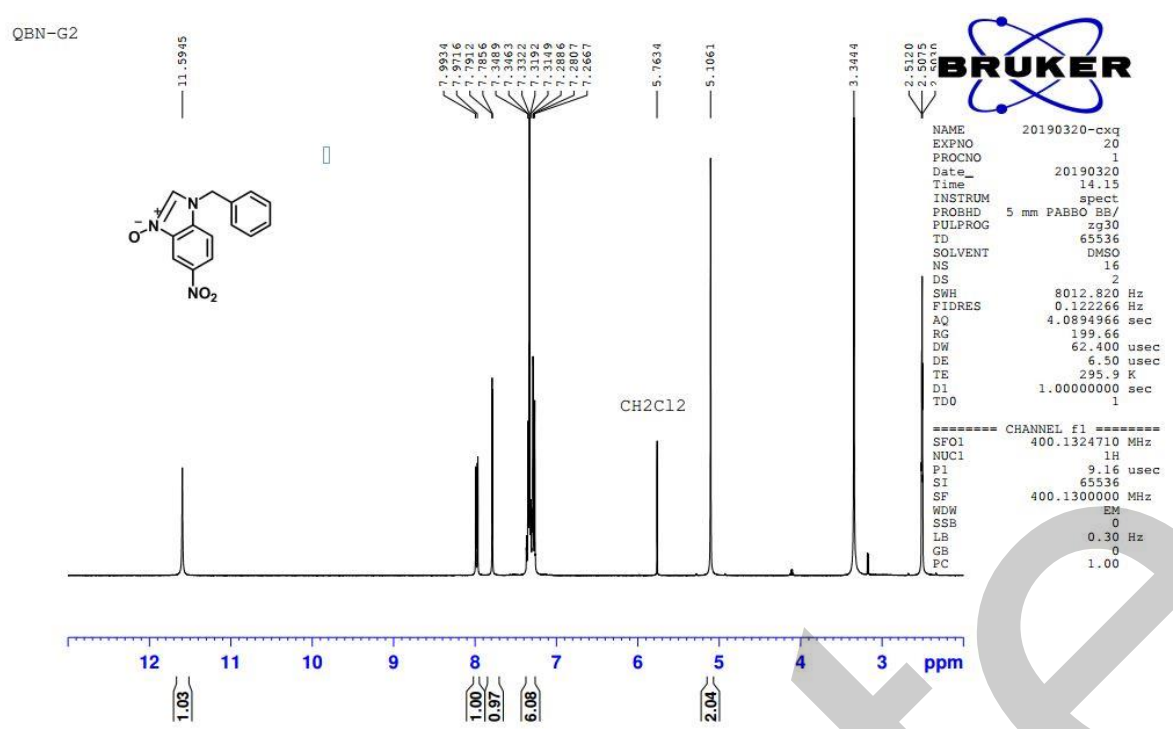

Figure S21. ${ }^{1} \mathrm{H}$ NMR spectrum of $3-G 2$ in DMSO- $d_{6}$.

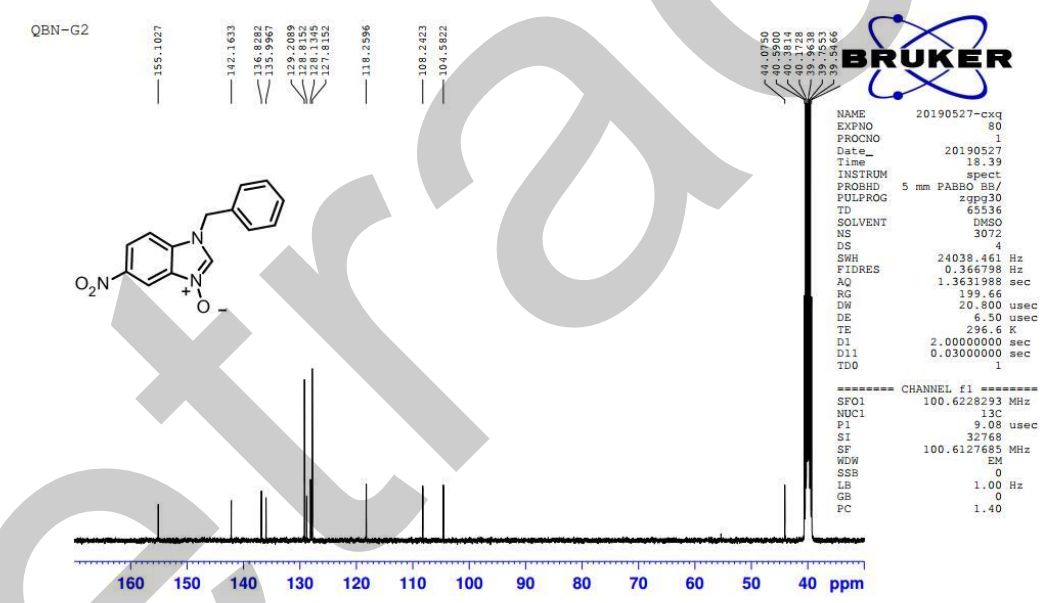

Figure S22. ${ }^{13} \mathrm{C}$ NMR spectrum of $3-G 2$ in DMSO- $d_{6}$. 


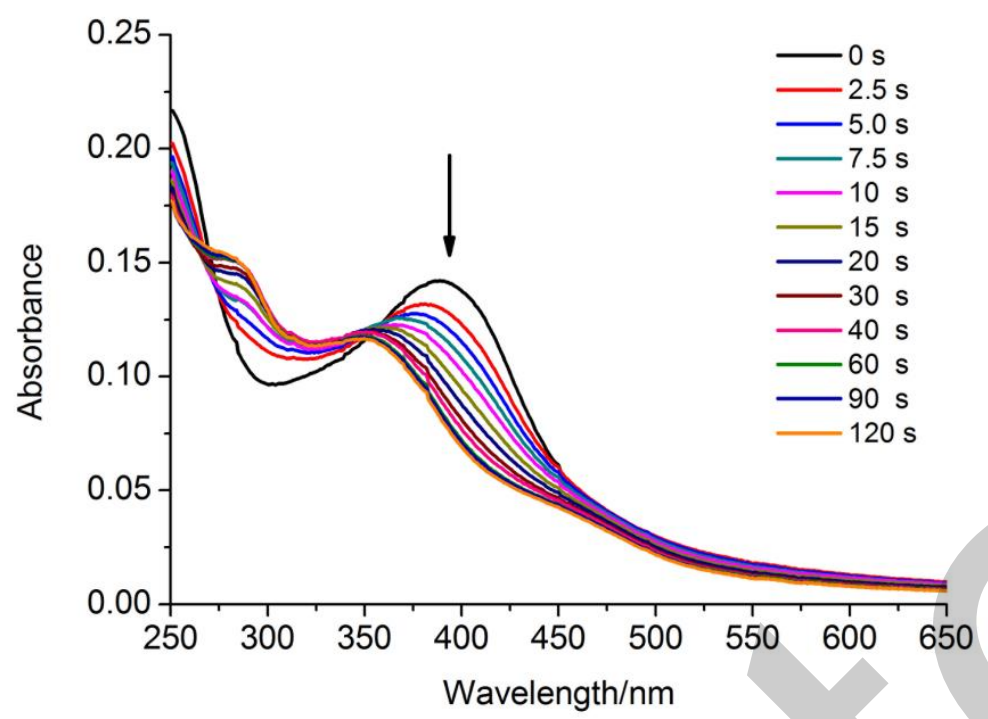

Figure S23.The absorption spectra of $4(10 \mu \mathrm{M})$ with different irradiation time $(365 \mathrm{~nm}, 85$ $\left.\mathrm{mW} / \mathrm{cm}^{2}\right)$ in HEPES buffer $(10 \mathrm{mM}, \mathrm{pH}=7.4)$.

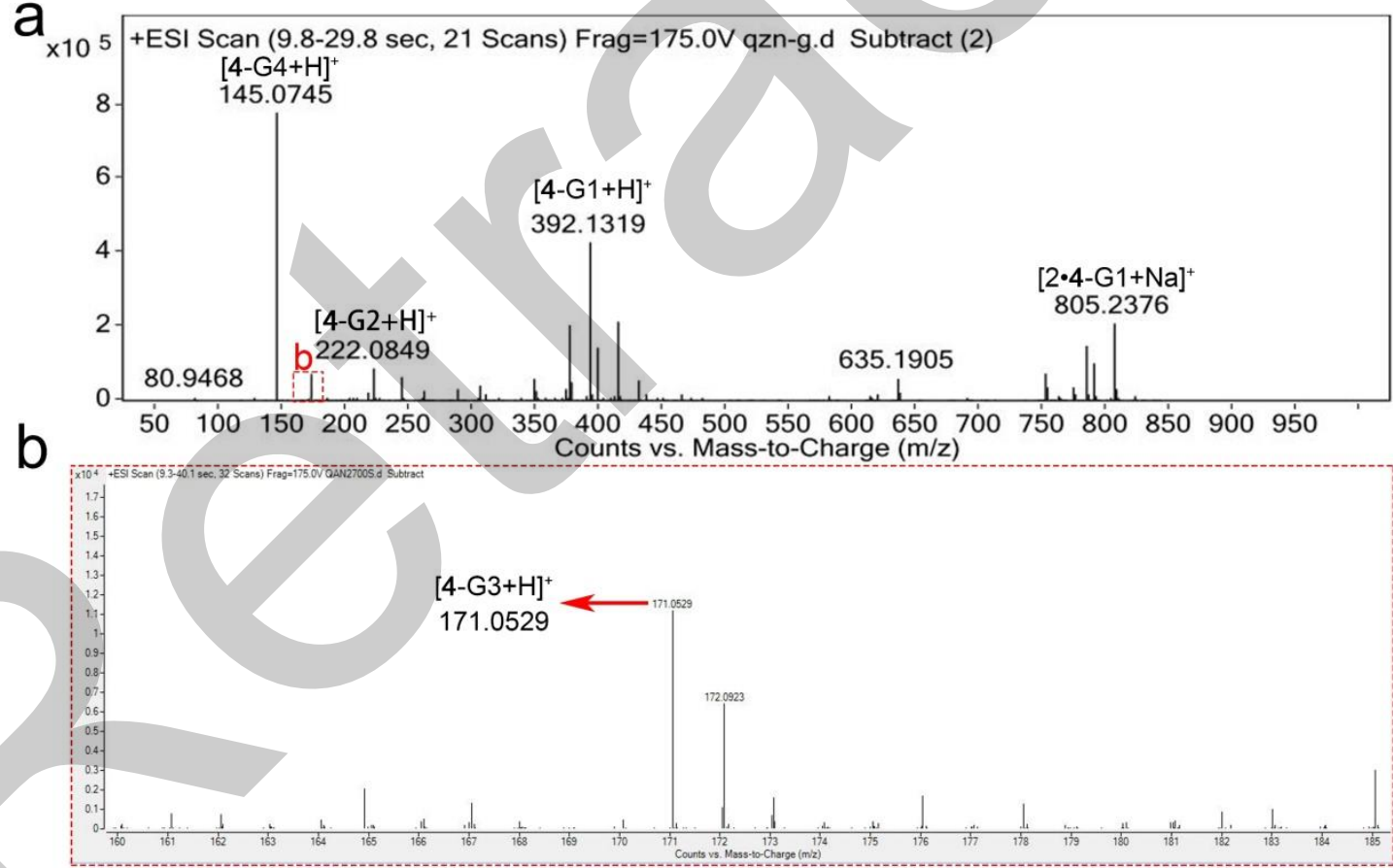

Figure S24. High Resolution Mass Spectrometry (a) and local amplification (b) of the compound 4 after irradiation $\left(365 \mathrm{~nm}, 85 \mathrm{~mW} / \mathrm{cm}^{2}\right)$. 

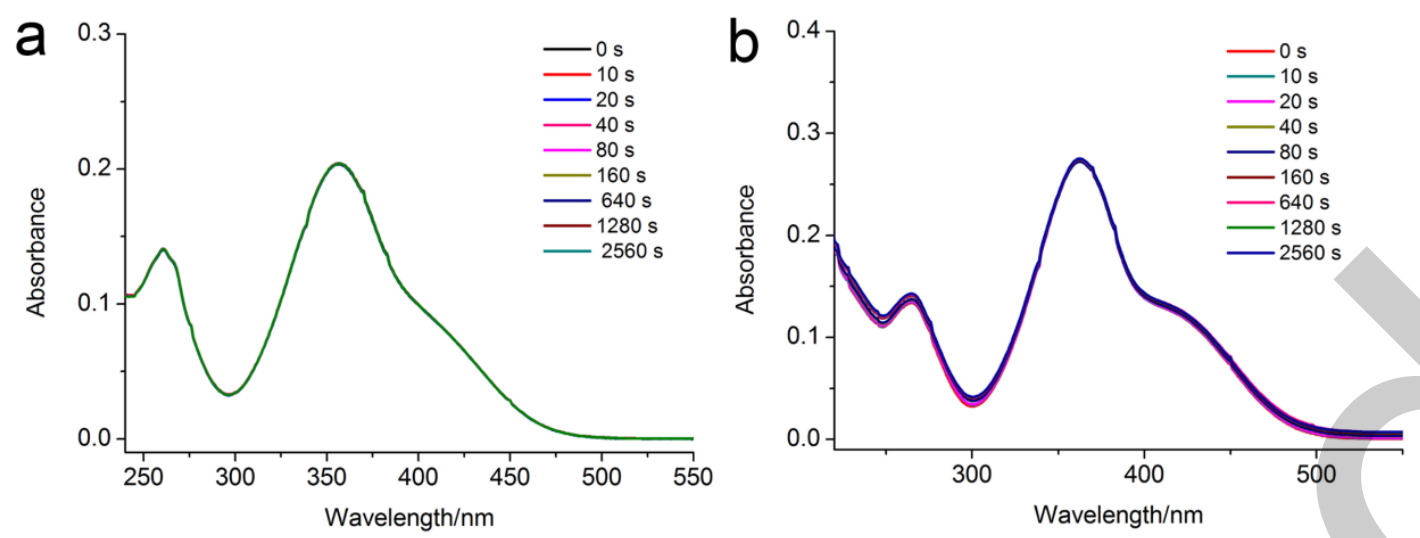

Figure S25.The absorption spectra of $10 \mu \mathrm{M} 2 \mathbf{i}$ (a) and $10 \mu \mathrm{M} 4 \mathbf{i}$ (b) with different irradiation time (365 $\left.\mathrm{nm}, 85 \mathrm{~mW} / \mathrm{cm}^{2}\right)$ in HEPES buffer $(10 \mathrm{mM}, \mathrm{pH}=7.4)$.
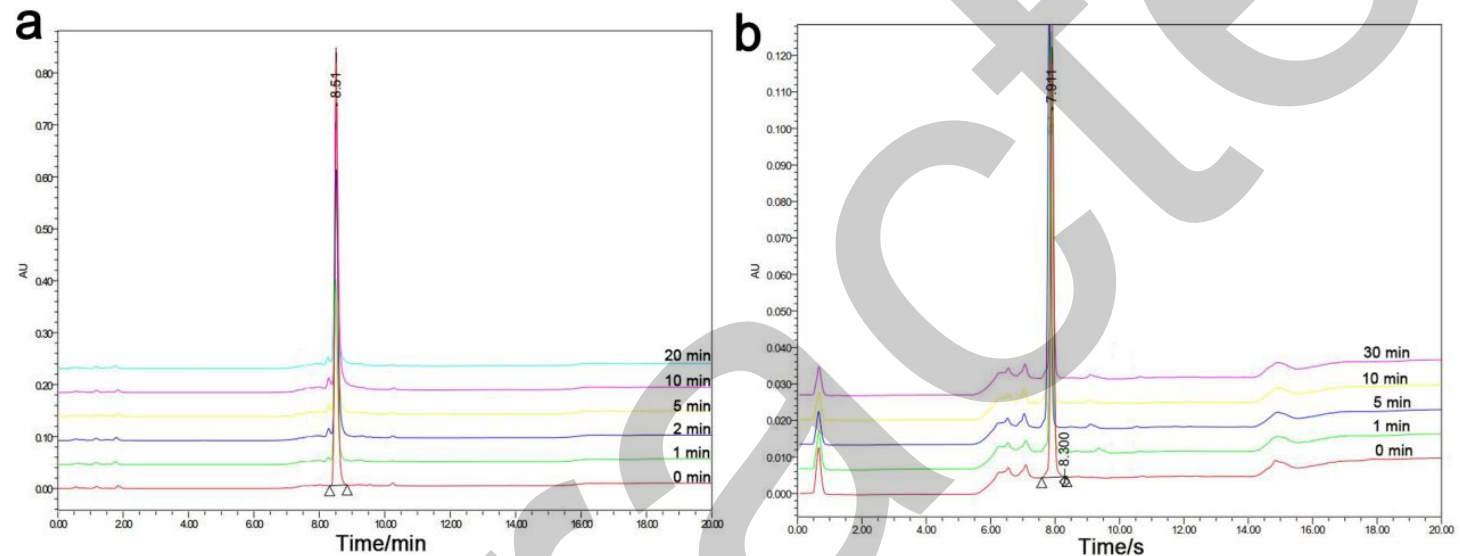

Figure S26. HPLC of $50 \mu \mathrm{mol} / \mathrm{L} 2 \mathbf{i}$ (a) and $50 \mu \mathrm{mol} / \mathrm{L} \mathrm{4i}$ (b) with different irradiation (365 nm, 85 $\left.\mathrm{mW} / \mathrm{cm}^{2}\right)$ time in HEPES buffer $(10 \mathrm{mM}, \mathrm{pH}=7.4)$. 

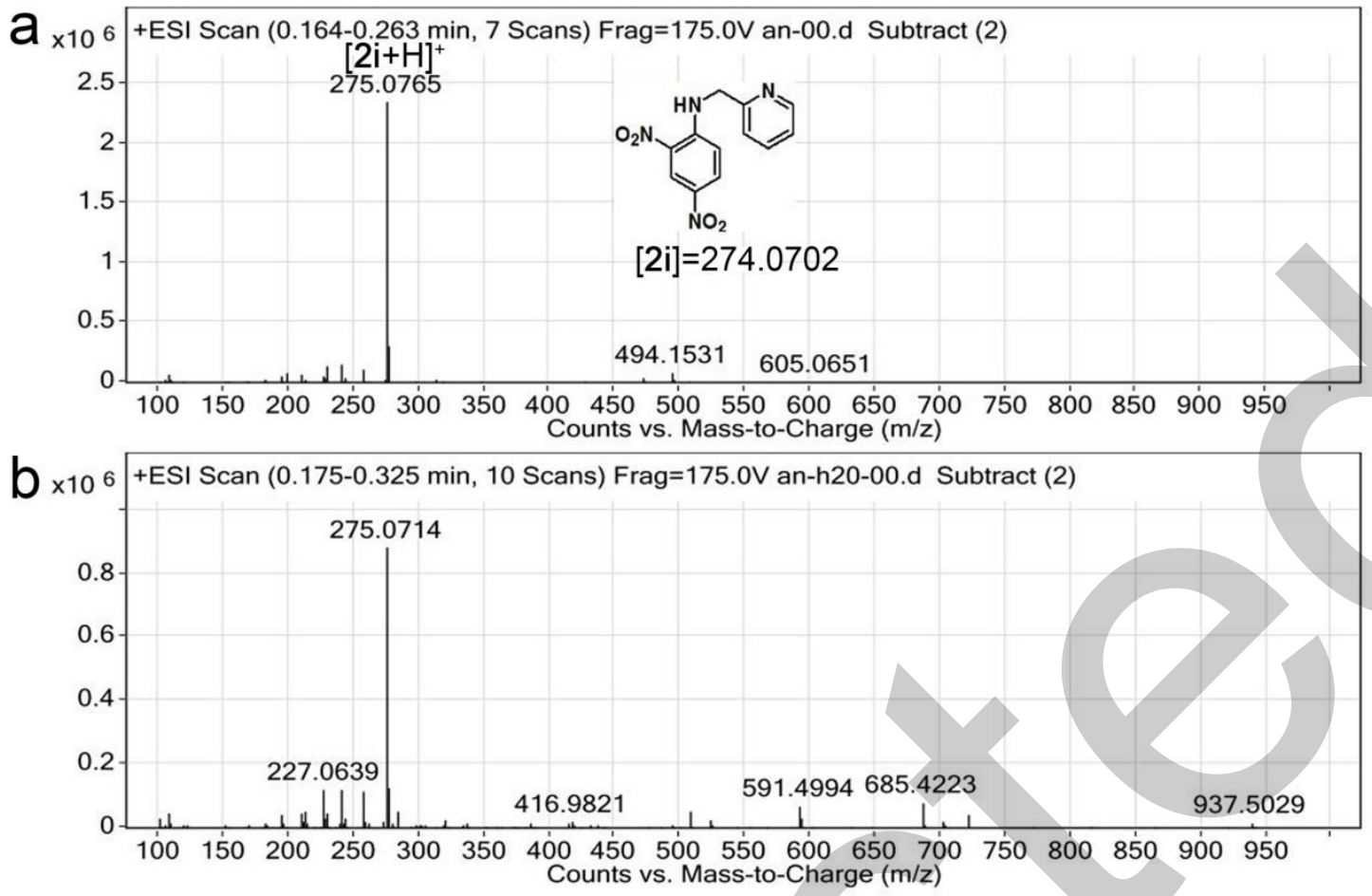

Figure S27. High resolution mass spectrometry of $\mathbf{2 i}$ before (a) and after (b) irradiation (365 nm, $\left.85 \mathrm{~mW} / \mathrm{cm}^{2}\right)$.
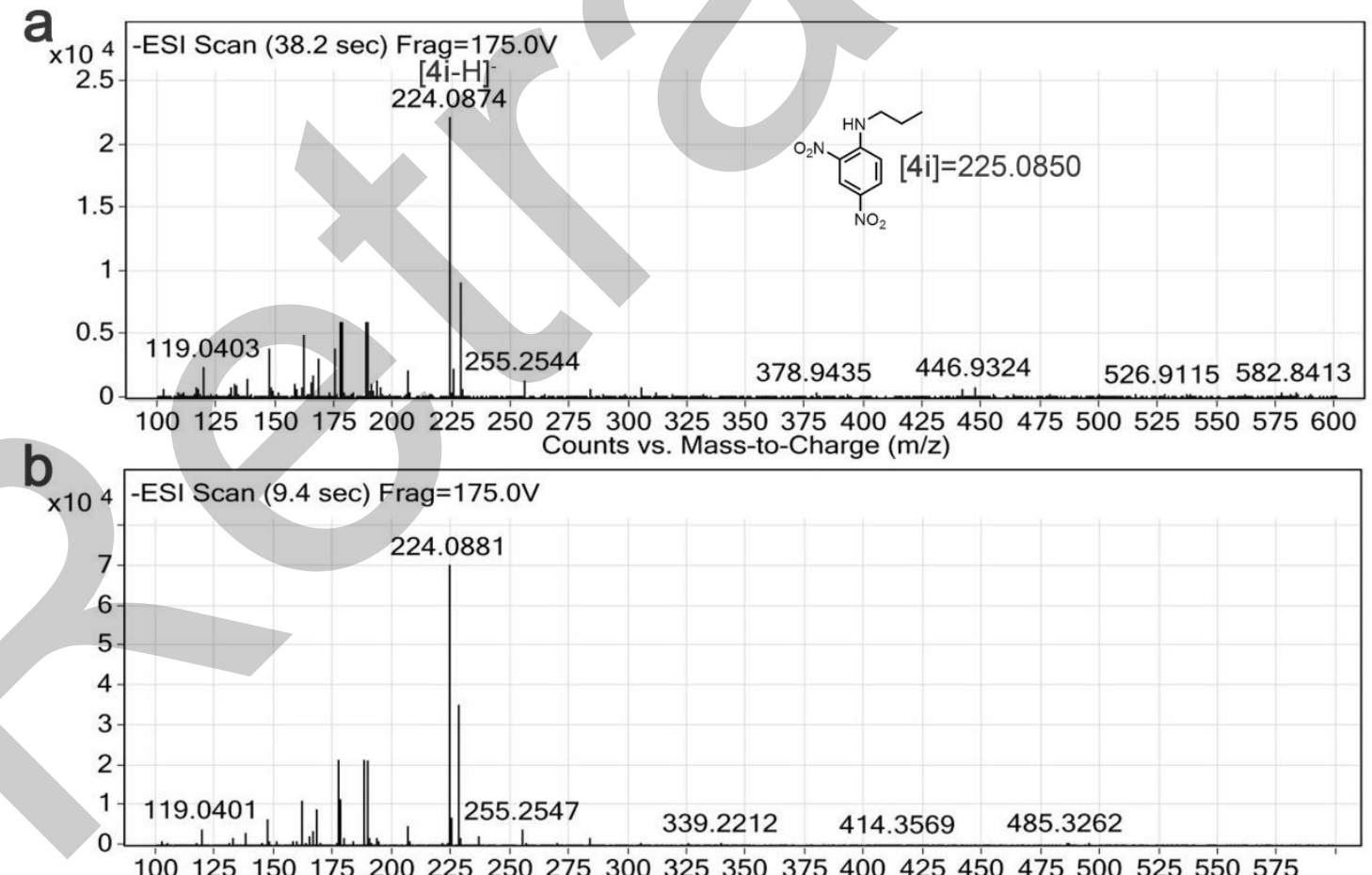

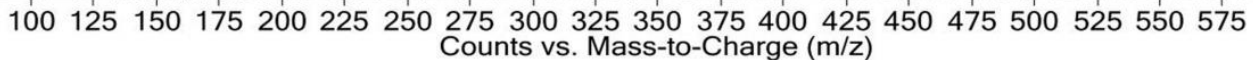

Figure S28. High resolution mass spectrometry (-ESI) of $\mathbf{4 i}$ before (a) and after (b) irradiation $\left(365 \mathrm{~nm}, 85 \mathrm{~mW} / \mathrm{cm}^{2}\right)$. 
a

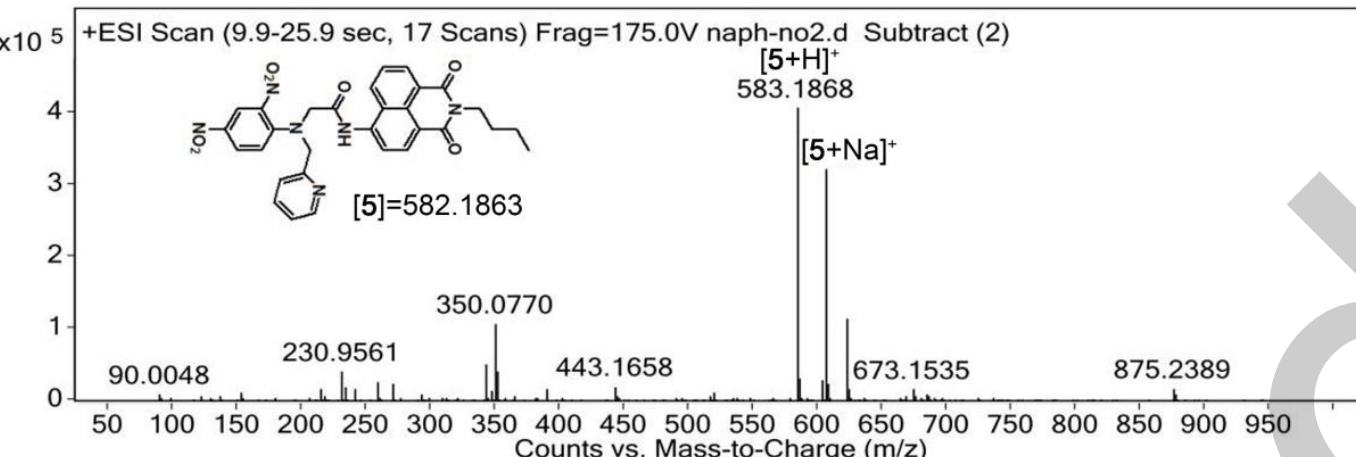
Counts vs. Mass-to-Charge $(\mathrm{m} / \mathrm{z})$

b $\times 10^{6}+$ +ESI Scan (0.137-0.320 min, 12 Scans) Frag=175.0V naphl-no2-g.d

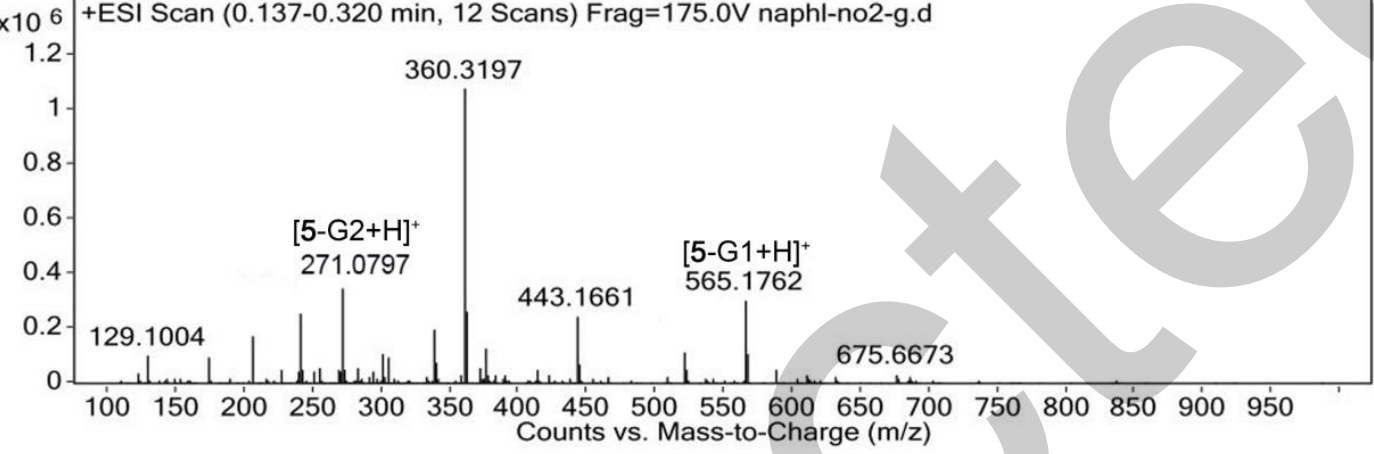

Figure S29. High resolution mass spectrometry (+ESI) of 5 before (a) and after (b) irradiation $\left(365 \mathrm{~nm}, 85 \mathrm{~mW} / \mathrm{cm}^{2}\right)$.

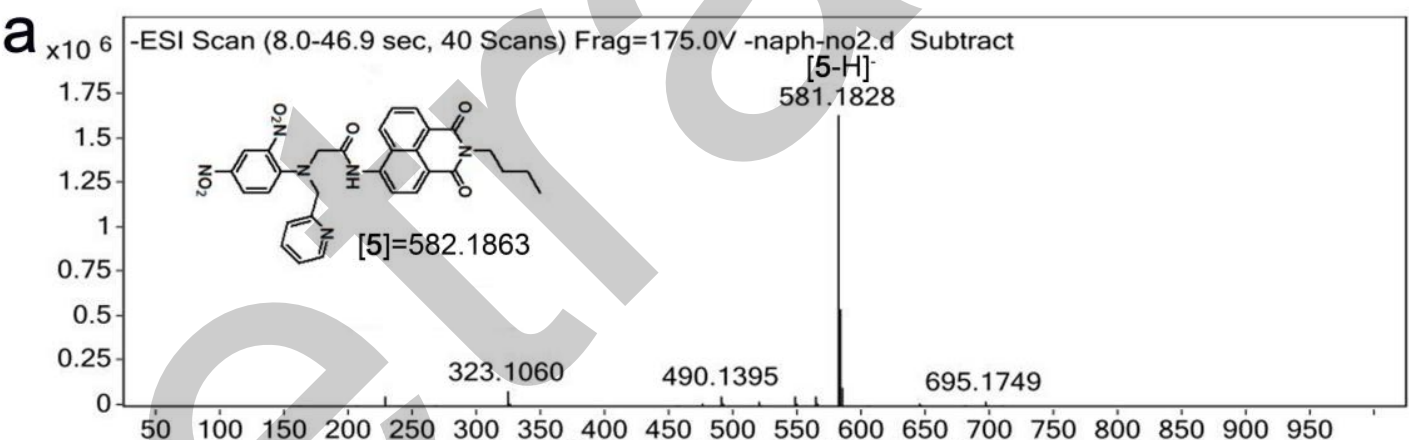

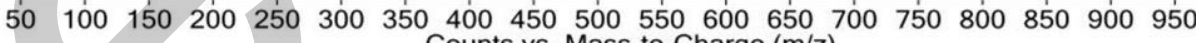

b $\times 10^{6}$-ESI Scan (0.185-0.528 min, 32 Scans) Frag=180.0 $-\mathrm{NAPH}-\mathrm{NO} 2-8.5-0 . \mathrm{d}$ Subtract

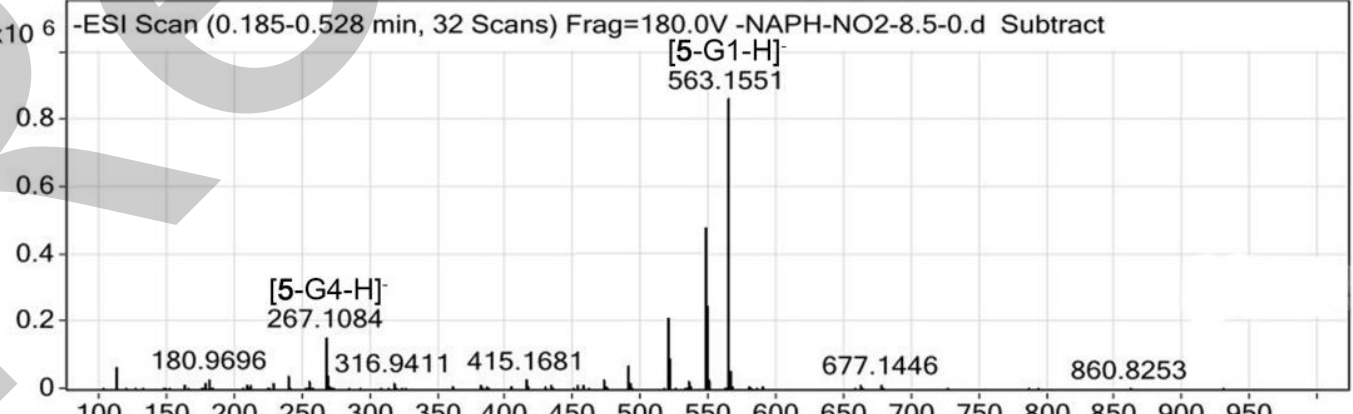

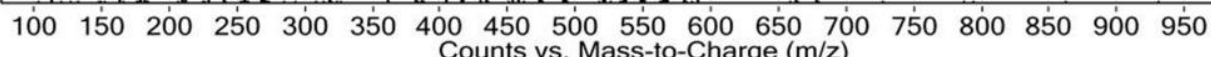

Figure S30. High resolution mass spectrometry (-ESI) of 5 before (a) and after (b) irradiation (365 $\left.\mathrm{nm}, 85 \mathrm{~mW} / \mathrm{cm}^{2}\right)$. 


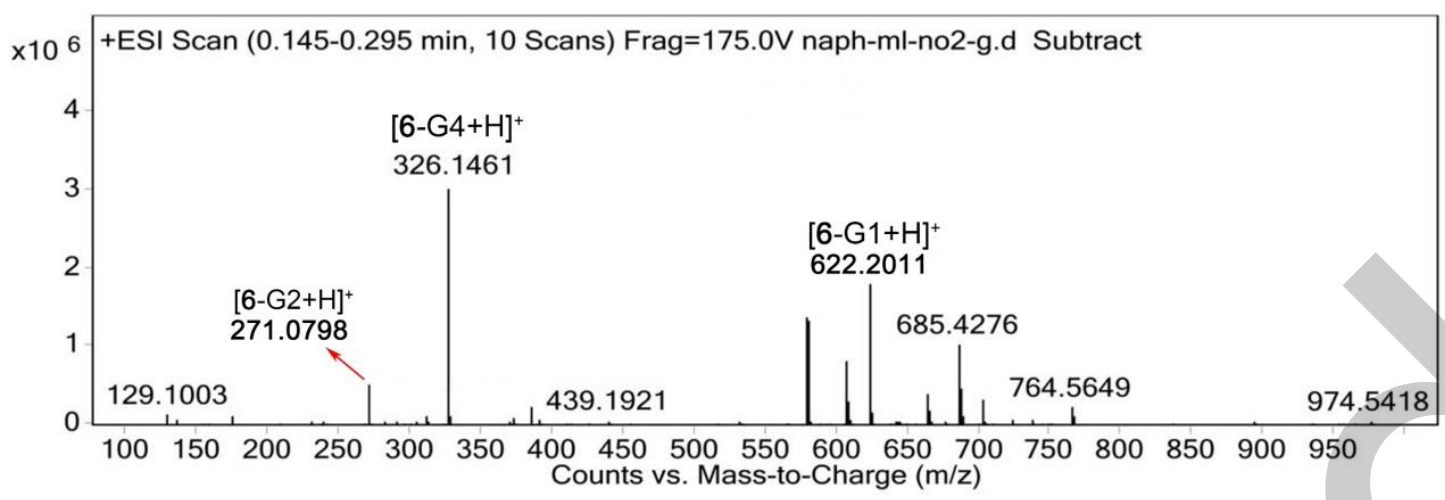

Figure S31. High resolution mass spectrometry of the compound $\mathbf{6}$ after irradiation $(365 \mathrm{~nm}, 85$ $\left.\mathrm{mW} / \mathrm{cm}^{2}\right)$.

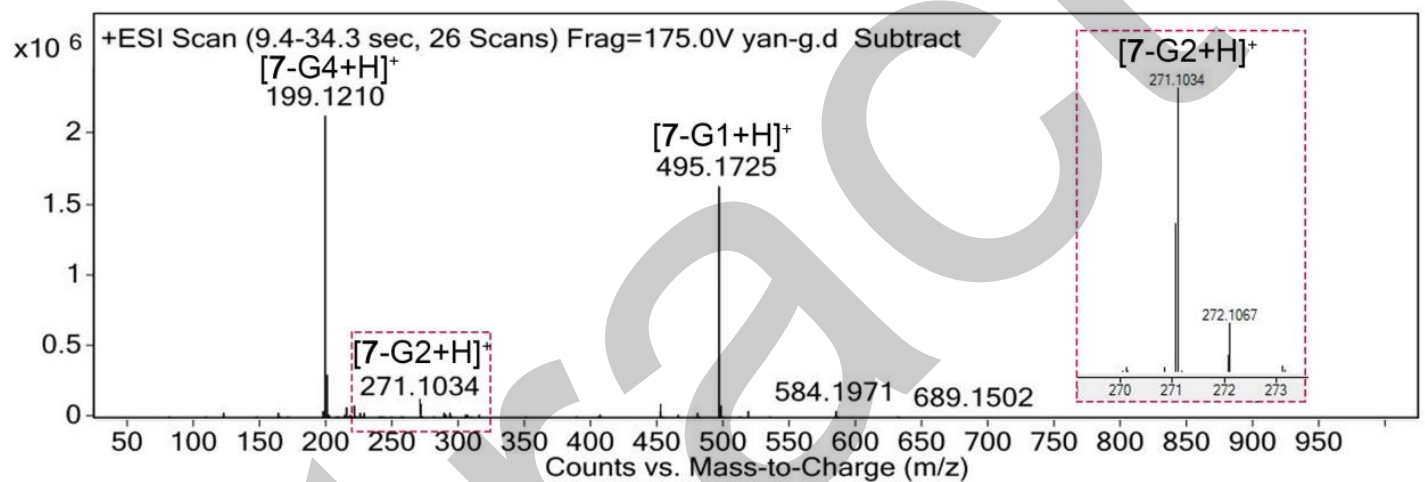

Figure S32. High resolution mass spectrometry and local amplification of 7 after irradiation (365 $\left.\mathrm{nm}, 85 \mathrm{~mW} / \mathrm{cm}^{2}\right)$. 

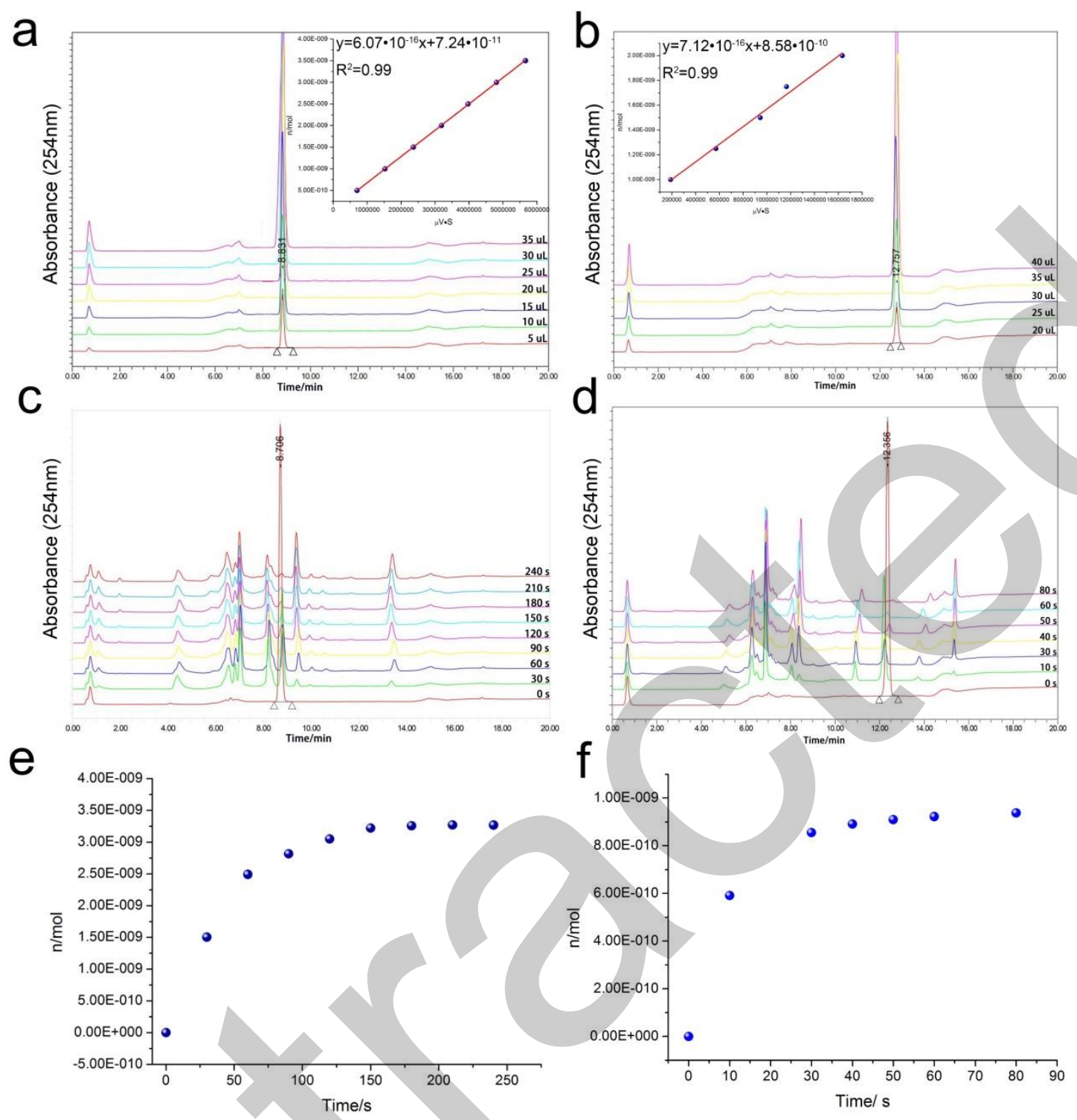

Figure S33. HPLC of $100 \mu \mathrm{mol} / \mathrm{L} 2$ (a) and $100 \mu \mathrm{mol} / \mathrm{L} 3$ (b) with different injection volume; HPLC of $100 \mu \mathrm{mol} / \mathrm{L} 2$ (c) and $50 \mu \mathrm{mol} / \mathrm{L} 3$ (d) with different irradiation $\left(365 \mathrm{~nm}, 85 \mathrm{~mW} / \mathrm{cm}^{2}\right)$ time in HEPES buffer (10 mM, pH=7.4). The decomposition amount of compound 2 (e) and $\mathbf{3}$ (f) were respectively plotted with exposure time according to corresponding HPLC data. Illustration: the linear relationship between the peak area and the amount of substance. The quantum efficiency of photolysis: $\Phi_{2}=0.10 ; \Phi_{3}=0.17$. 

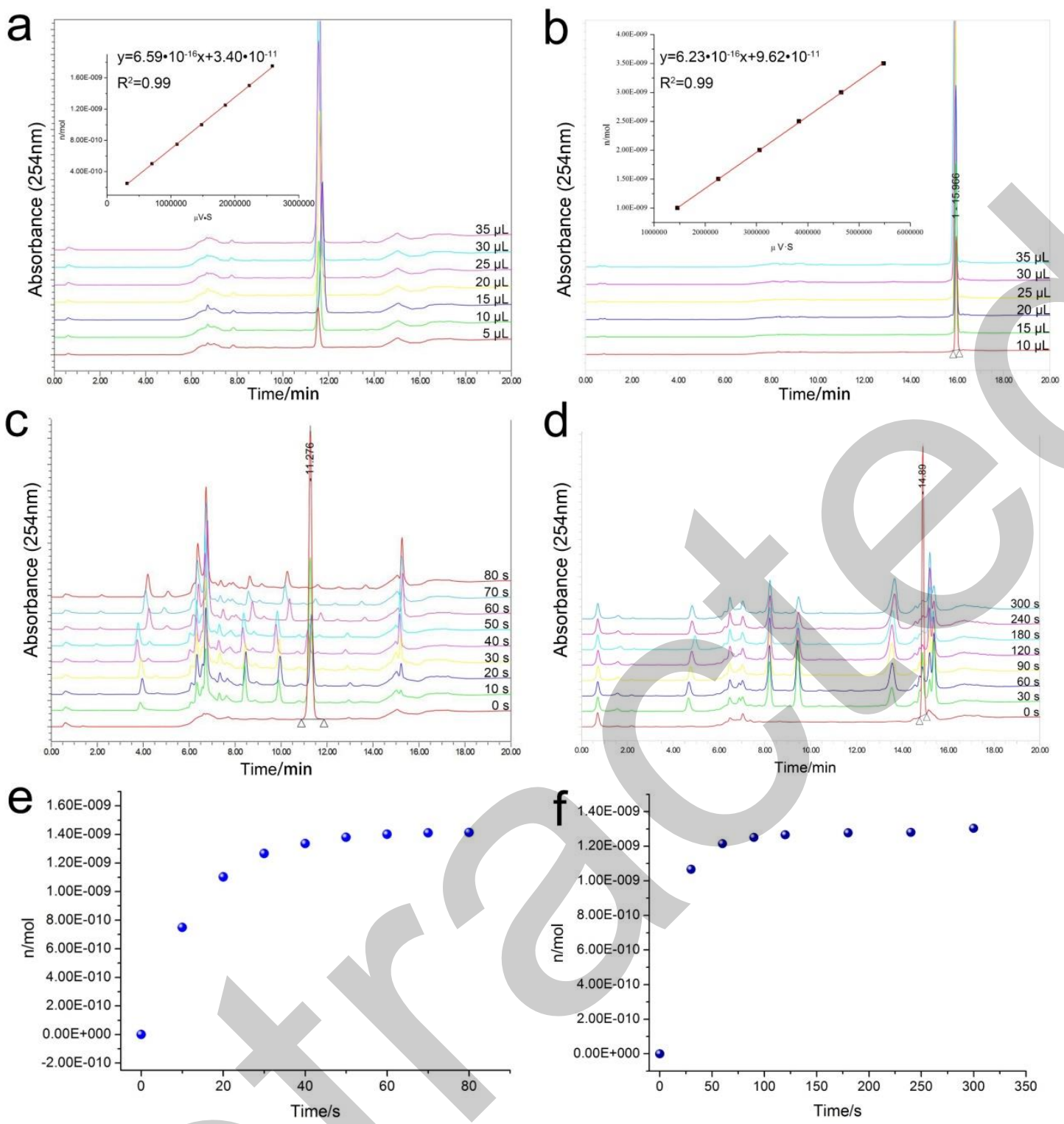

Figure S34. HPLC of $50 \mu \mathrm{mol} / \mathrm{L} 4$ (a) and $100 \mu \mathrm{mol} / \mathrm{L} 5$ (b) with different injection volume; HPLC of $50 \mu \mathrm{mol} / \mathrm{L} 4$ (c) and $50 \mu \mathrm{mol} / \mathrm{L} 5$ (d) with different irradiation $\left(365 \mathrm{~nm}, 85 \mathrm{~mW} / \mathrm{cm}^{2}\right)$ time in HEPES buffer (10 mM, pH=7.4); The decomposition amount of compound 4 (e) and 5 (f) were respectively plotted with exposure time according to corresponding HPLC data. Illustration: the linear relationship between the peak area and the amount of substance. The quantum efficiency of photolysis: $\Phi_{4}=0.22 ; \Phi_{5}=0.28$. 

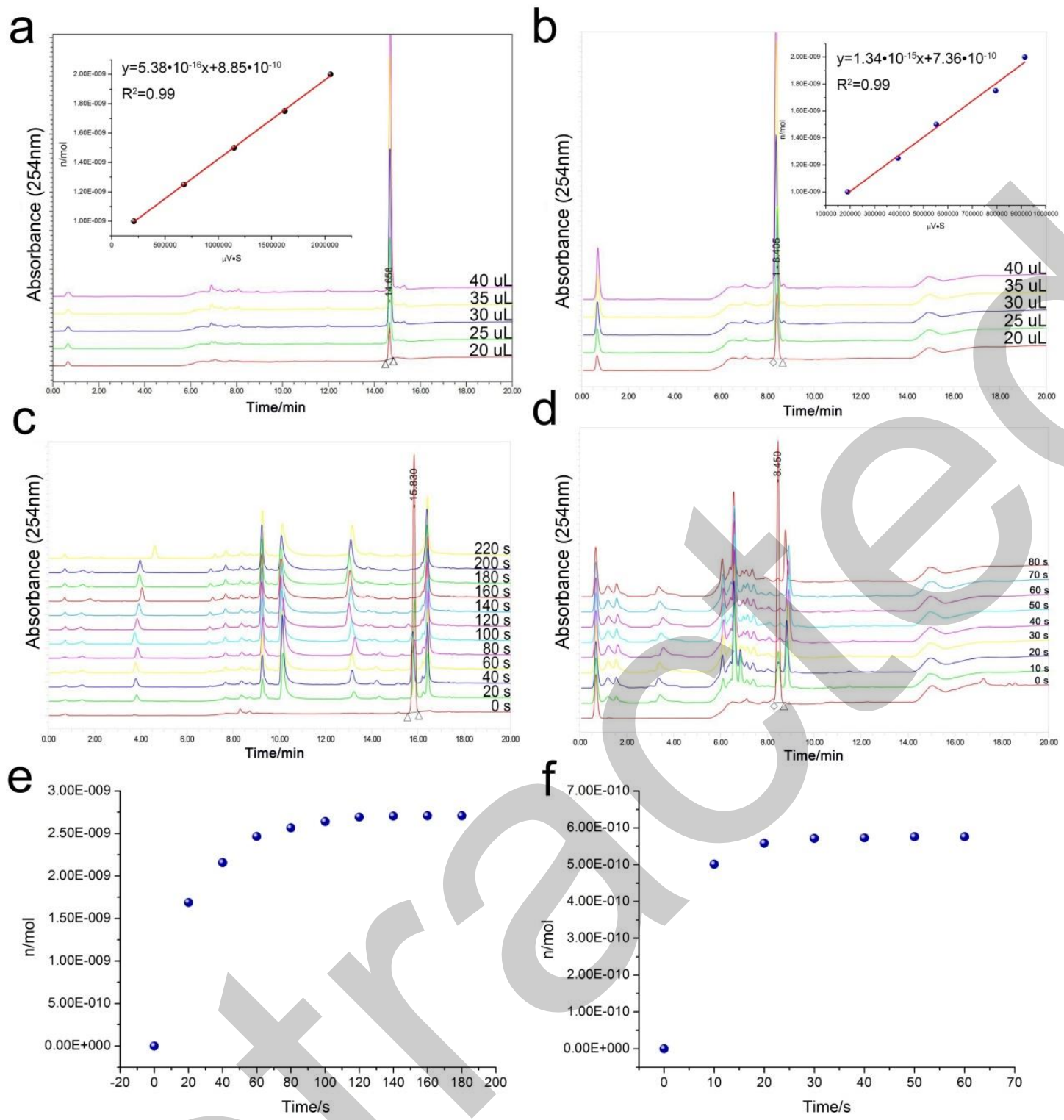

Figure S35. HPLC of $50 \mu \mathrm{mol} / \mathrm{L} 6$ (a) and $100 \mu \mathrm{mol} / \mathrm{L} 7$ (b) with different injection volume; HPLC of $50 \mu \mathrm{mol} / \mathrm{L} 6$ (c) and $50 \mu \mathrm{mol} / \mathrm{L} 7$ (d) with different irradiation $\left(365 \mathrm{~nm}, 85 \mathrm{~mW} / \mathrm{cm}^{2}\right)$ time in HEPES buffer (10 mM, pH=7.4); The decomposition amount of compound 6 (e) and 7 (f) were respectively plotted with exposure time according to corresponding HPLC data. Illustration: the linear relationship between the peak area and the amount of substance. The quantum efficiency of photolysis: $\Phi_{6}=0.24 ; \Phi_{7}=0.30$. 


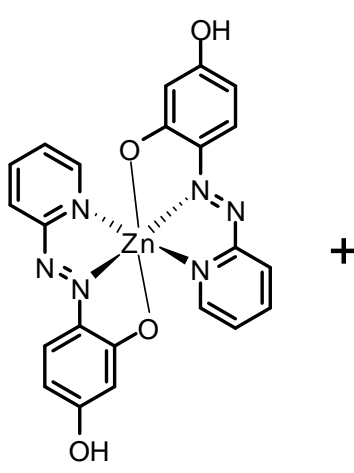

[Zn(PAR $)_{2}$ ]<smiles>C=CC#CCC</smiles>

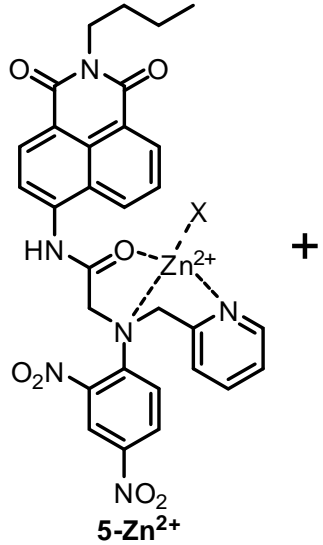<smiles>[N]=Nc1ccccn1</smiles><smiles>N=N</smiles>

PAR

Figure S36. Schematic diagram of competitive complexation of $\mathrm{Zn}^{2+}$ between the probe 5 and PAR.
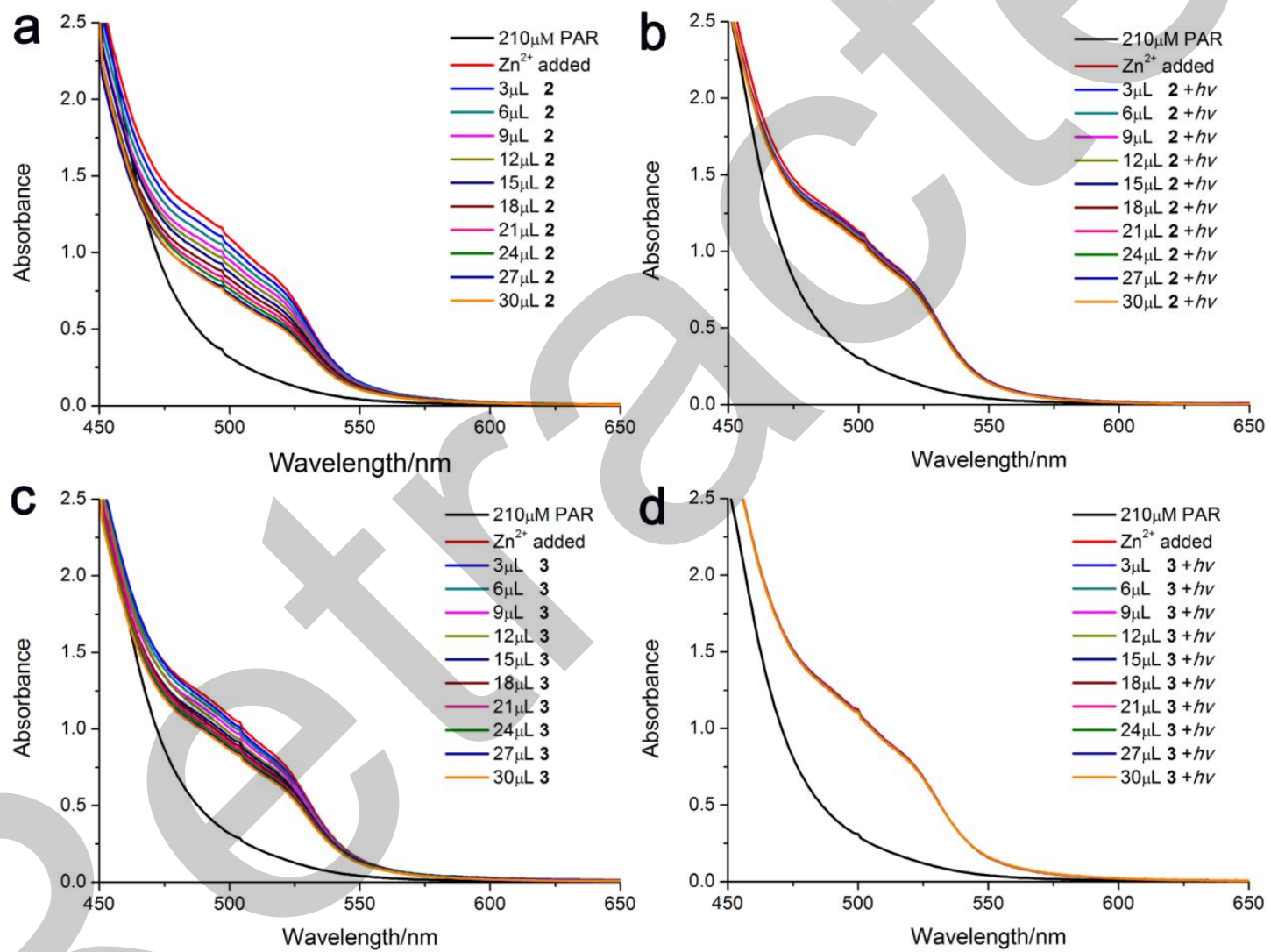

Figure S37. Partial UV-vis spectrum of $210 \mu \mathrm{M}\left[\mathrm{Zn}(\mathrm{PAR})_{2}\right]$ complex titrated with $2 \mathrm{mM}$ of 2 (a) and 3 (b) in HEPES buffer (10 mM, pH 7.4). Partial UV-vis spectrum of $210 \mu \mathrm{M}\left[\mathrm{Zn}(\mathrm{PAR})_{2}\right]$ complex titrated with $2 \mathrm{mM}$ of 2 (b) and 3 (d) after UV irradiation $\left(365 \mathrm{~nm}, 85 \mathrm{~mW} / \mathrm{cm}^{2}\right)$ for 3 min in HEPES buffer (10 mM, pH 7.4). 

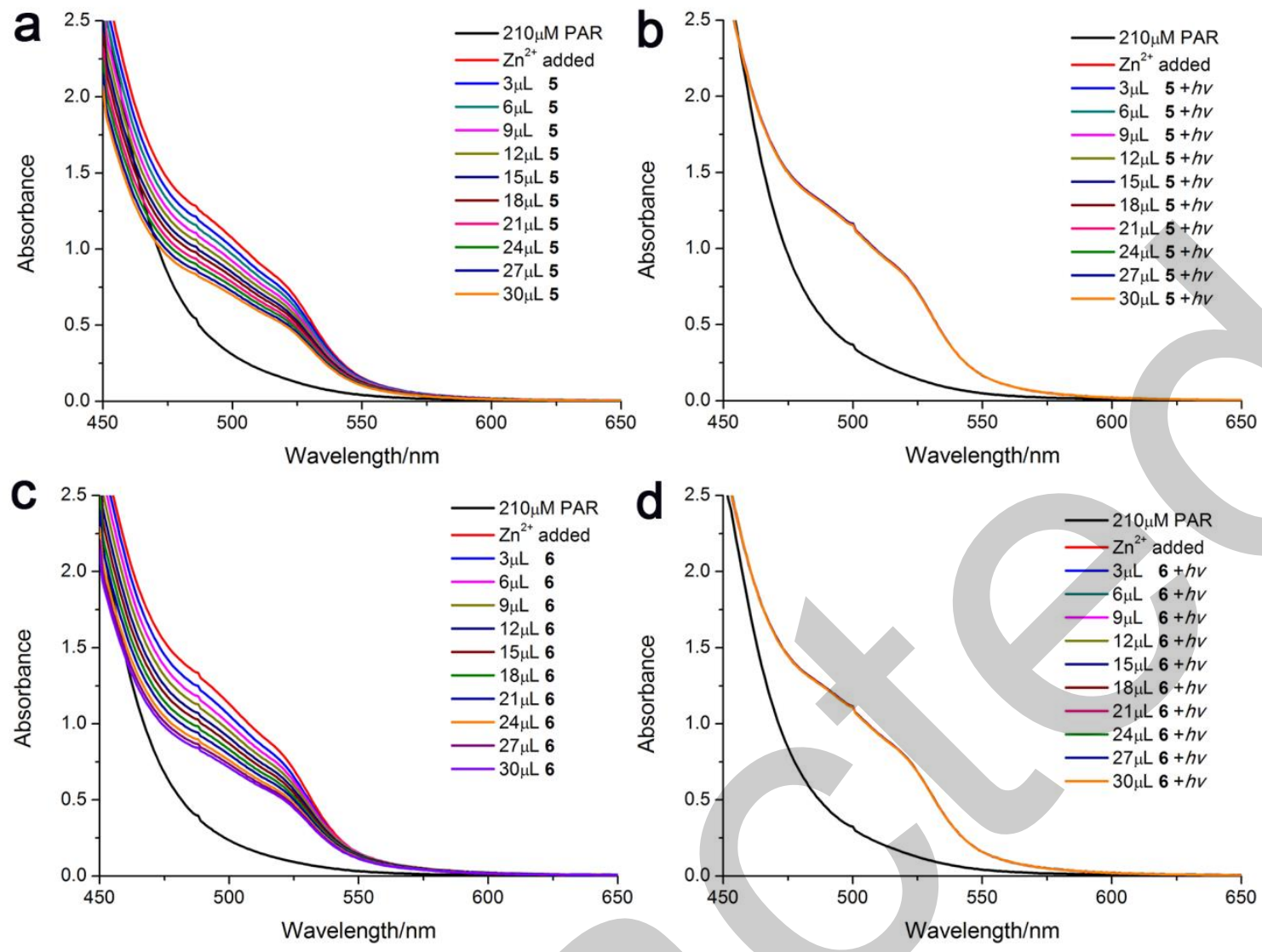

Figure S38. Partial UV-vis spectrum of $210 \mu \mathrm{M}\left[\mathrm{Zn}(\mathrm{PAR})_{2}\right]$ complex titrated with $2 \mathrm{mM}$ of 5 (a) and 6 (b) in HEPES buffer (10 mM, pH 7.4). Partial UV-vis spectrum of $210 \mu \mathrm{M}$ [Zn (PAR) $\left.)_{2}\right]$ complex titrated with $2 \mathrm{mM}$ of $\mathbf{5}$ (b) and $\mathbf{6}$ (d) after UV irradiation $\left(365 \mathrm{~nm}, 85 \mathrm{~mW} / \mathrm{cm}^{2}\right)$ for 3 min in HEPES buffer (10 mM, pH 7.4).

Table S1. Apparent dissociation constant of compounds to $\mathrm{Zn}^{2+}$ before and after irradiation (365 $\left.\mathrm{nm}, 85 \mathrm{~mW} / \mathrm{cm}^{2}\right)\left(\mathrm{K}_{\mathrm{d}}^{\prime}\right.$ is apparent dissociation constants of compounds with $\mathrm{Zn}^{2+}$ after photolysis)

\begin{tabular}{|c|c|c|c|}
\hline Compound & $\mathrm{K}_{\mathrm{d}}$ & $\mathrm{K}_{\mathrm{d}}^{\prime}($ After hv $)$ & $\triangle \mathrm{K}_{\mathrm{d}}=\mathrm{K}_{\mathrm{d}}^{\prime} / \mathrm{K}_{\mathrm{d}}$ \\
\hline $\mathbf{2}$ & $9.3 \pm 0.7 \mathrm{nM}$ & $84.6 \pm 3 \mathrm{nM}$ & $\approx 9.10$ \\
\hline $\mathbf{3}$ & $25.1 \pm 1.3 \mathrm{nM}$ & $391.6 \pm 5.7 \mu \mathrm{M}$ & $\approx 15601$ \\
\hline $\mathbf{5}$ & $11.3 \pm 0.6 \mathrm{nM}$ & $958.1 \pm 11.6 \mu \mathrm{M}$ & $\approx 84787$ \\
\hline $\mathbf{6}$ & $11.0 \pm 0.9 \mathrm{nM}$ & $934.4 \pm 14.1 \mu \mathrm{M}$ & $\approx 84945$ \\
\hline
\end{tabular}




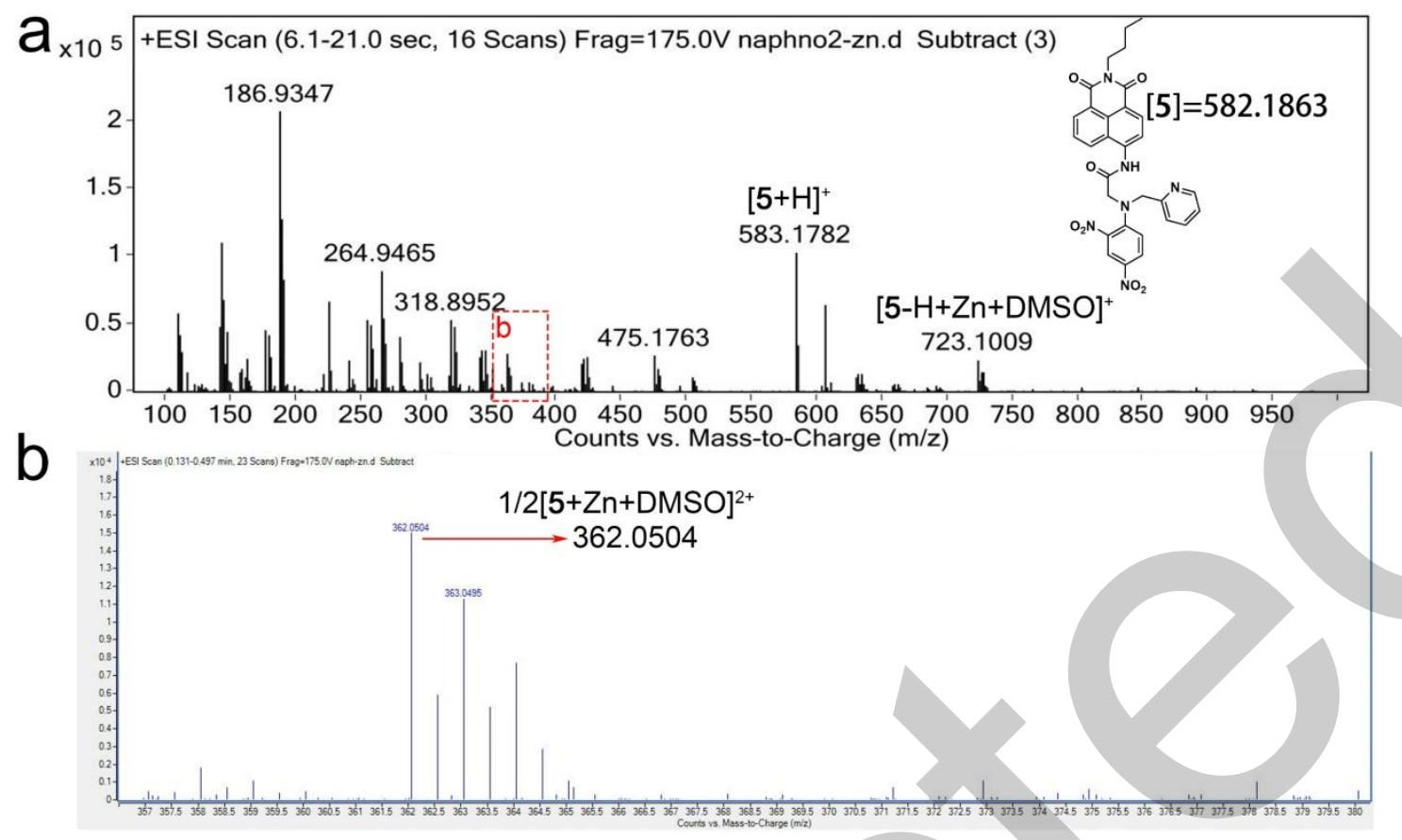

Figure S39. High resolution mass spectrometry (a) and local amplification (b) of 5 with $\mathrm{Zn}^{2+}$.

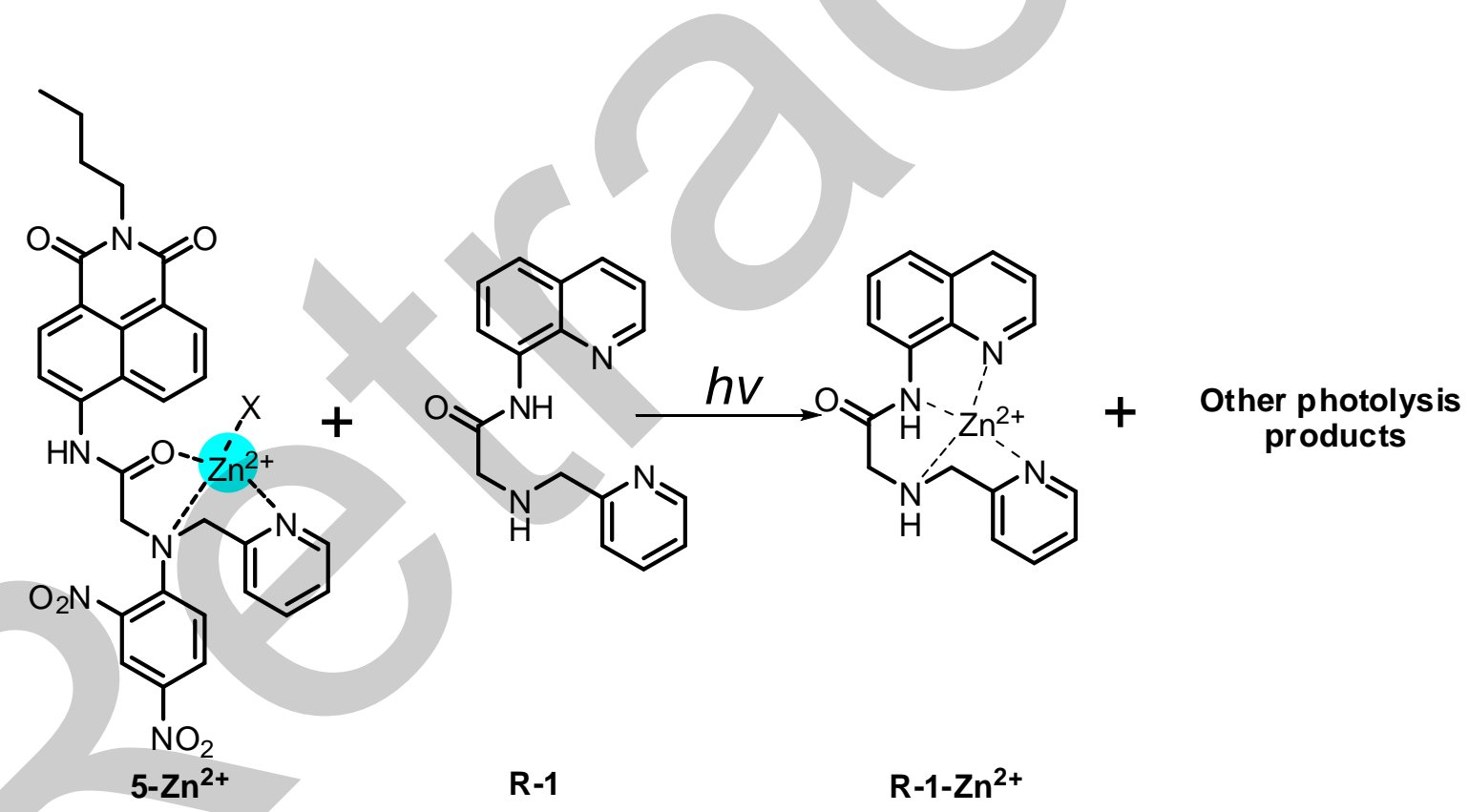

Figure S40. Schematic diagram of zinc ion photoreleased from $\mathbf{5}$ monitored by probe R-1. 

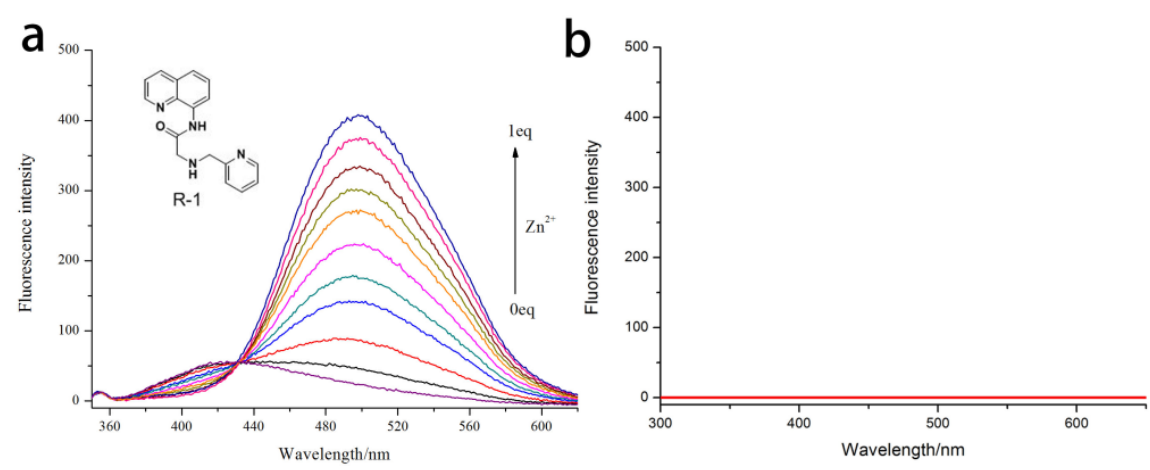

Figure S41. (a) The structure of the probe R-1 and its fluorescence response to zinc ion in HEPES buffer (pH=7.4, $10 \mathrm{mM}$ ); (b) Fluorescence spectrum of 5-G4 in HEPES buffer ( $\mathrm{pH}=7.4,10 \mathrm{mM})$. $\lambda_{\mathrm{ex}}=315 \mathrm{~nm}$, slit: $5 \mathrm{~nm} / 5 \mathrm{~nm}$.

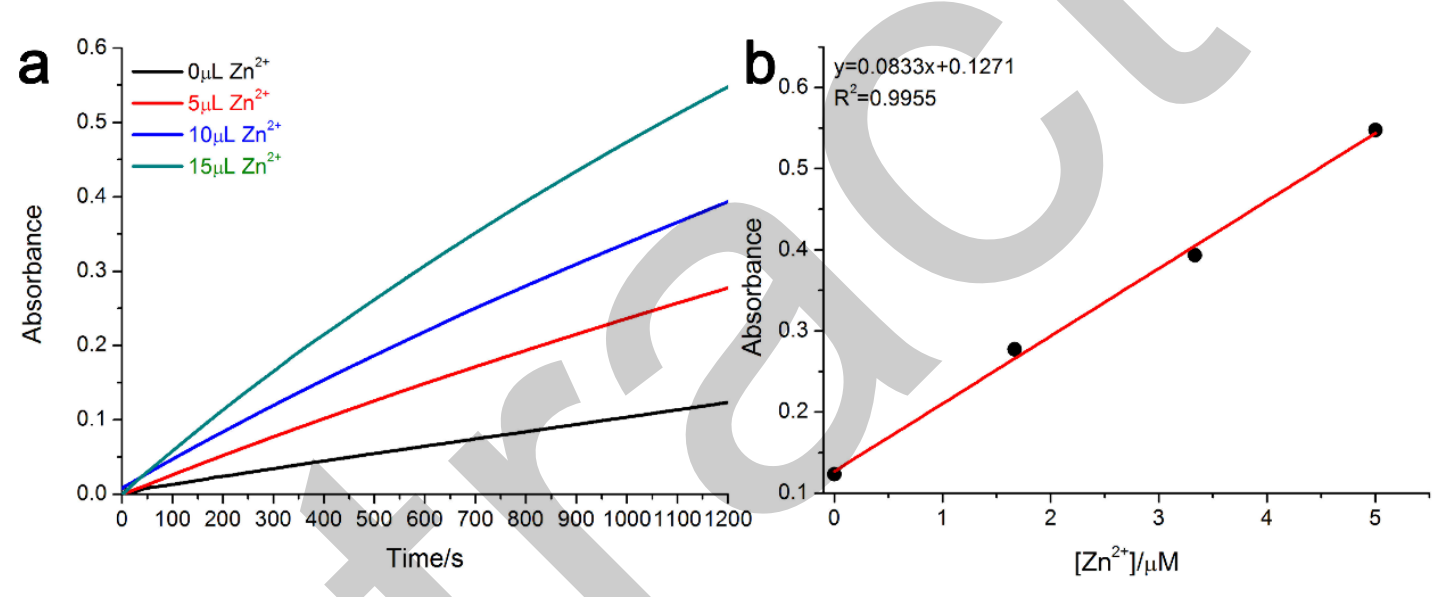

Figure S42. (a) Kinetic curve (the absorbance at $400 \mathrm{~nm}$ ) of deactivated carbonic anhydrase (deCA) was monitored using 4-Nitrophenolacetate (NPA, $125 \mu \mathrm{M}$ ) as the substrate, when different amounts of $\mathrm{Zn}^{2+}$ were added. deCA was obtained by removing zinc ions of CA; (b) The linear relationship between the absorbance ( $400 \mathrm{~nm})$ at $1200 \mathrm{~s}$ and the concentration of $\mathrm{Zn}^{2+}(0-5 \mu \mathrm{M})$. 


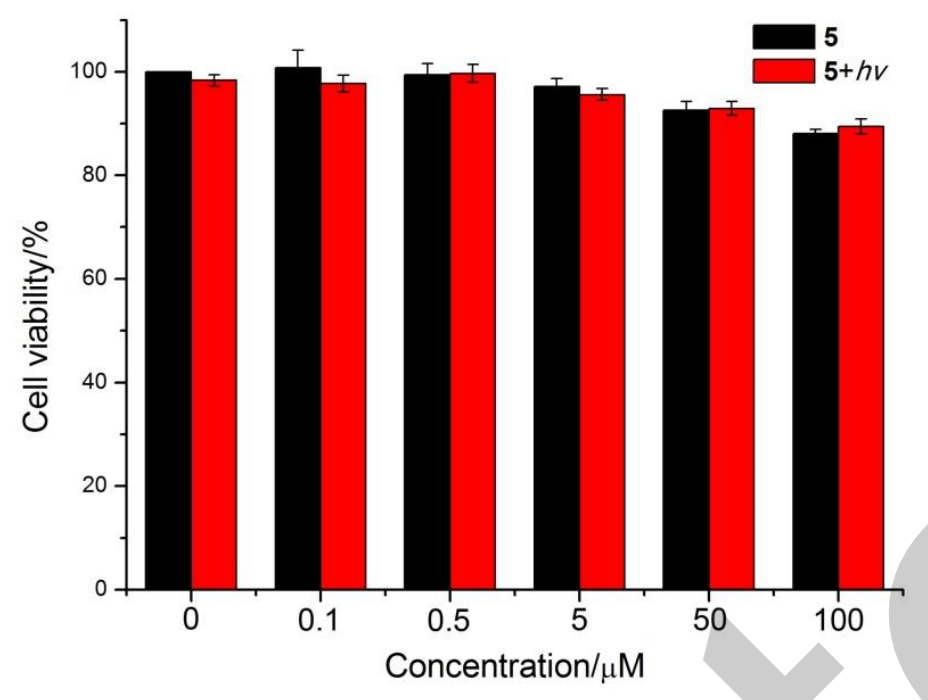

Figure S43. Cell viability of HEK 293 cells treated by $5-\mathrm{Zn}^{2+}$ with different concentrations $(0-100$ $\mu \mathrm{M})$ before (black) and after (red) irradiation $\left(365 \mathrm{~nm}, 85 \mathrm{~mW} / \mathrm{cm}^{2}\right)$.

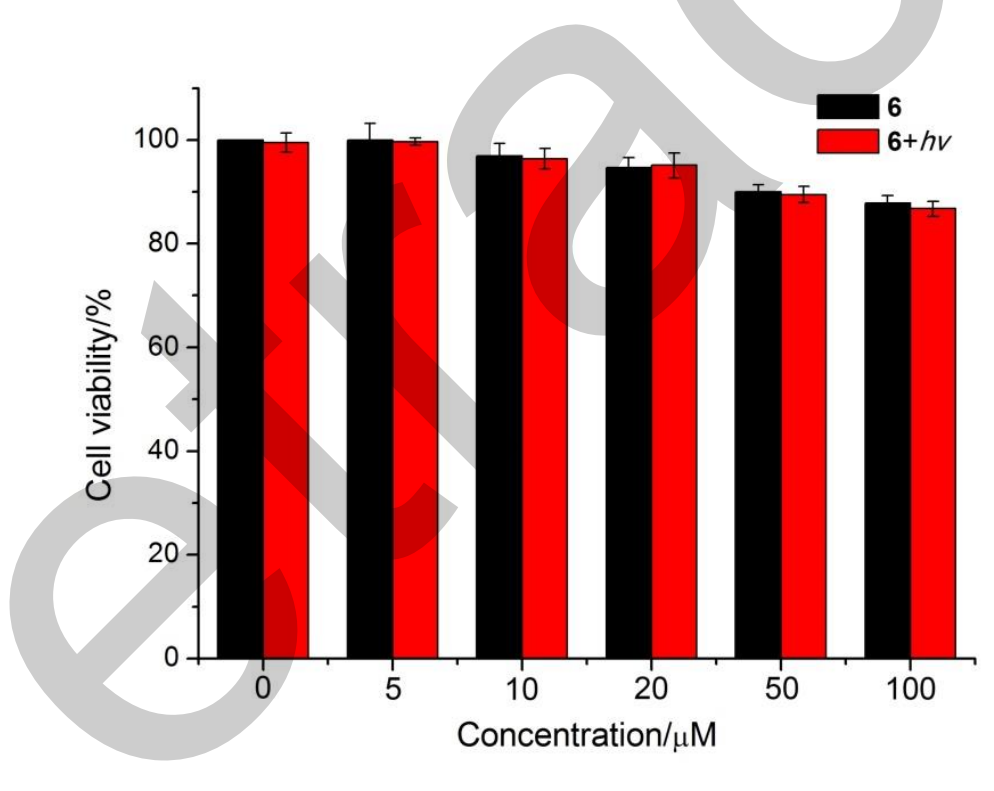

Figure S44. Cell viability of Hela cells treated by $6-\mathrm{Zn}^{2+}$ with different concentrations $(0-100 \mu \mathrm{M})$ before (black) and after (red) irradiation $\left(365 \mathrm{~nm}, 85 \mathrm{~mW} / \mathrm{cm}^{2}\right)$. 


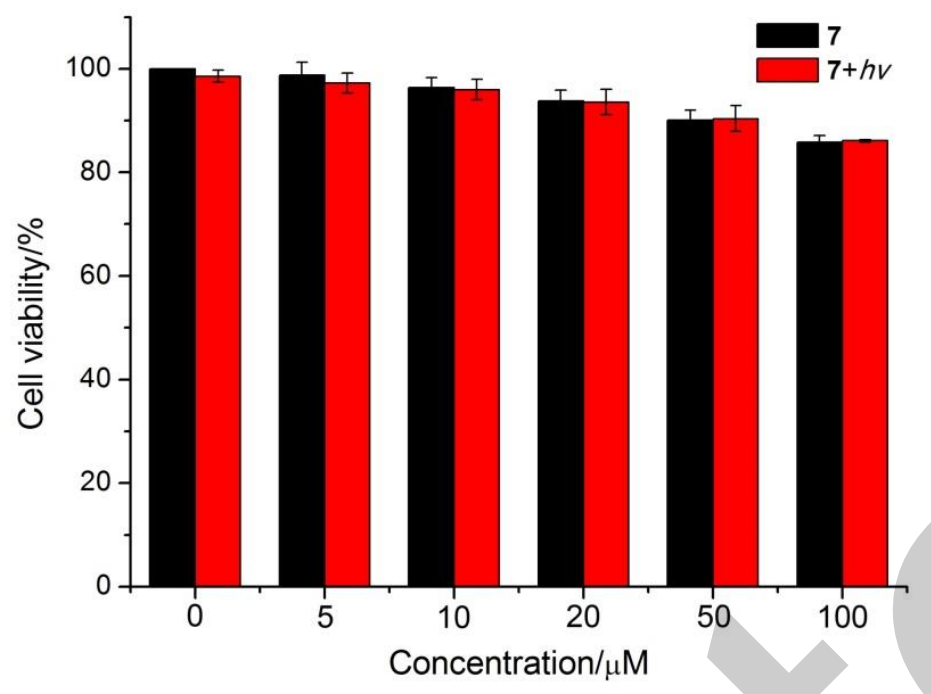

Figure S45. Cell viability of primary mouse cardiomyocytes treated by 7 with different concentrations $(0-100 \mu \mathrm{M})$ before (black) and after (red) irradiation $\left(365 \mathrm{~nm}, 85 \mathrm{~mW} / \mathrm{cm}^{2}\right)$. GN
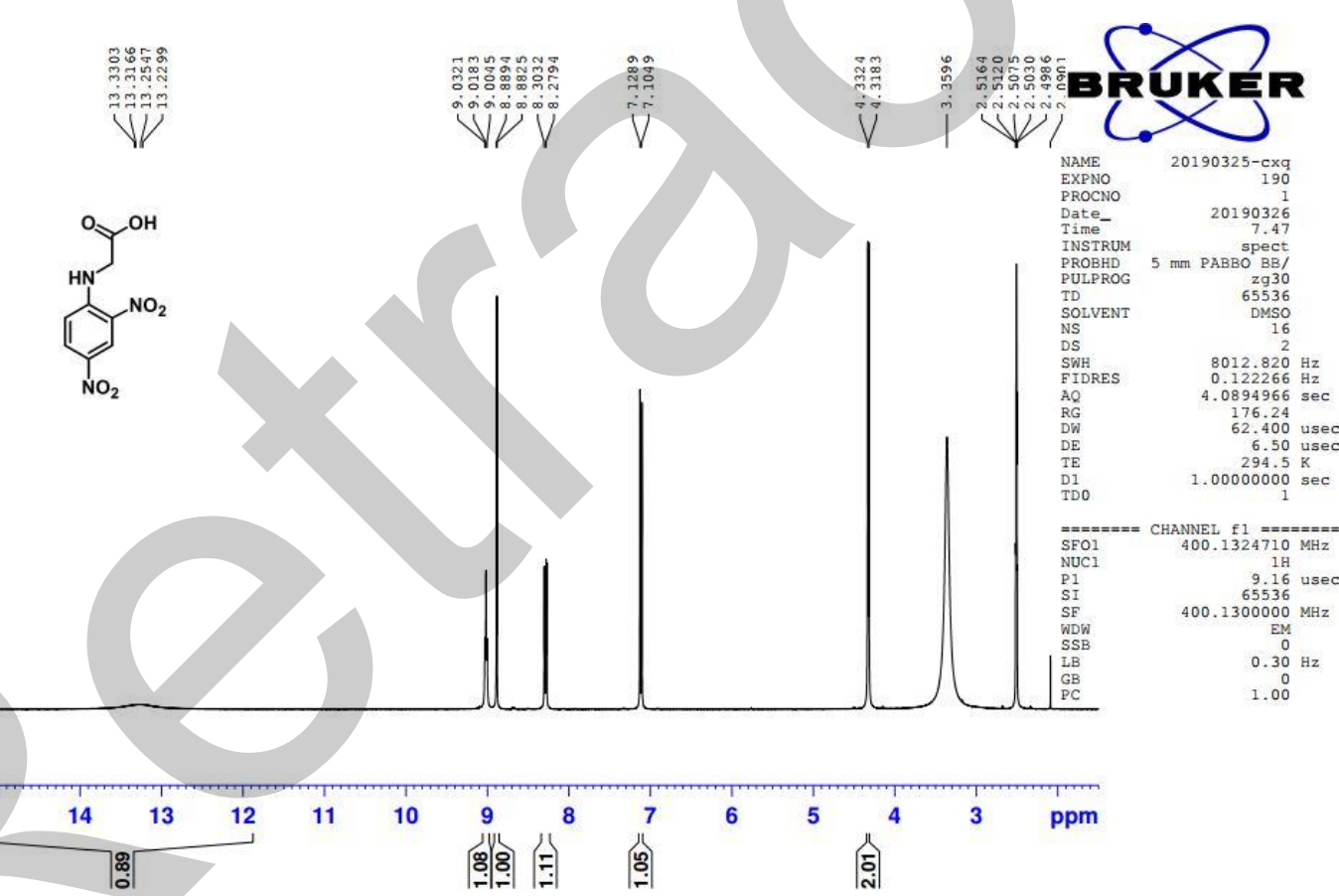

Figure S46. ${ }^{1} \mathrm{H}$ NMR spectrum of $\mathbf{1}$ in DMSO- $d_{6}$ 
GN

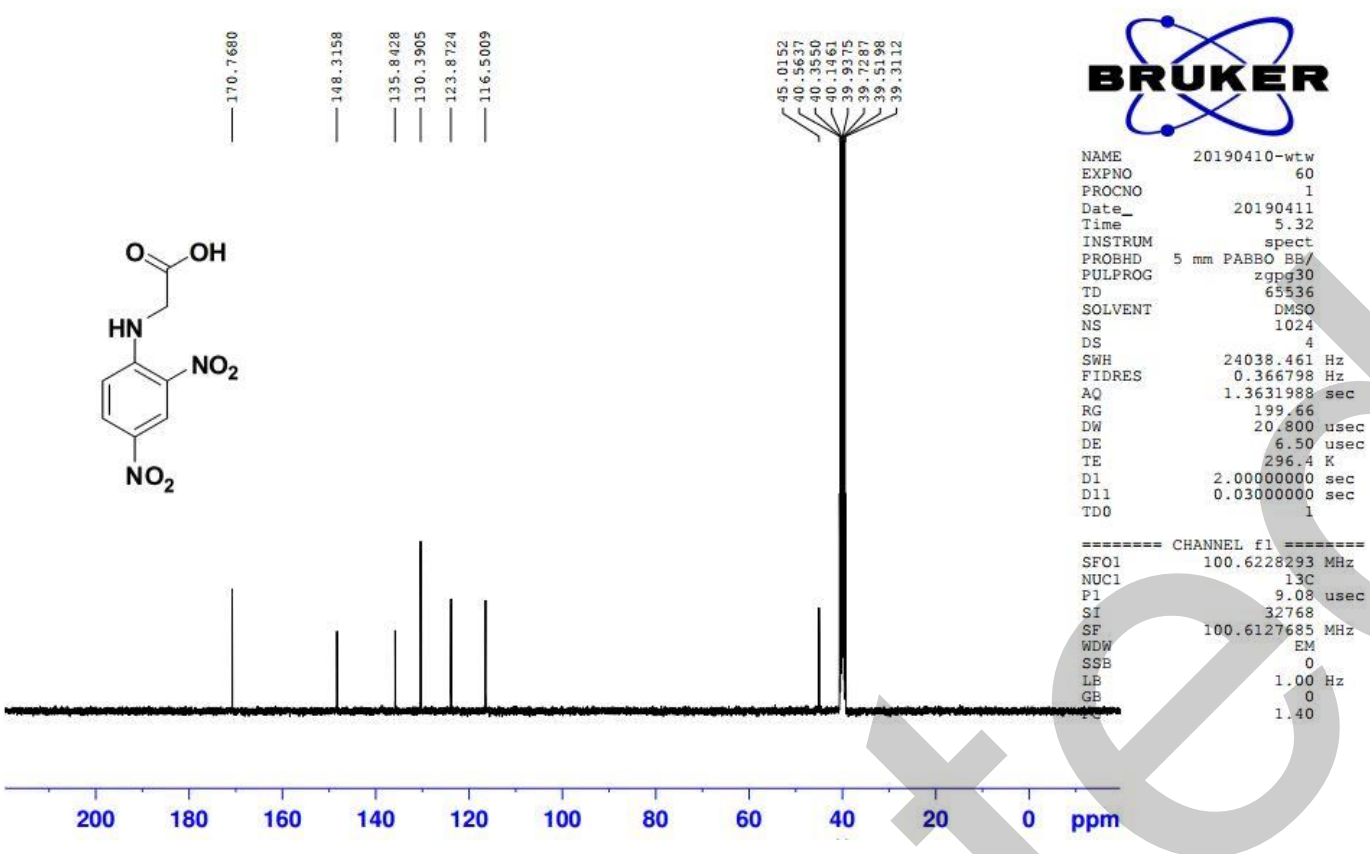

Figure S47. ${ }^{13} \mathrm{C}$ NMR spectrum of $\mathbf{1}$ in DMSO- $d_{6}$.

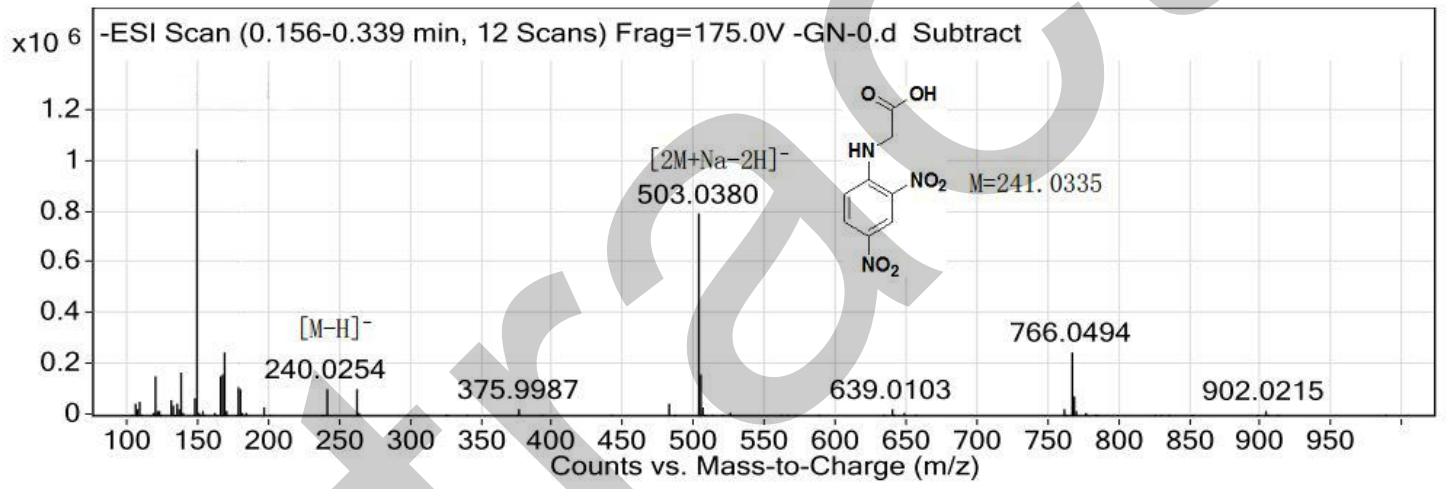

Figure S48. High resolution mass spectrometry of $\mathbf{1}$. 


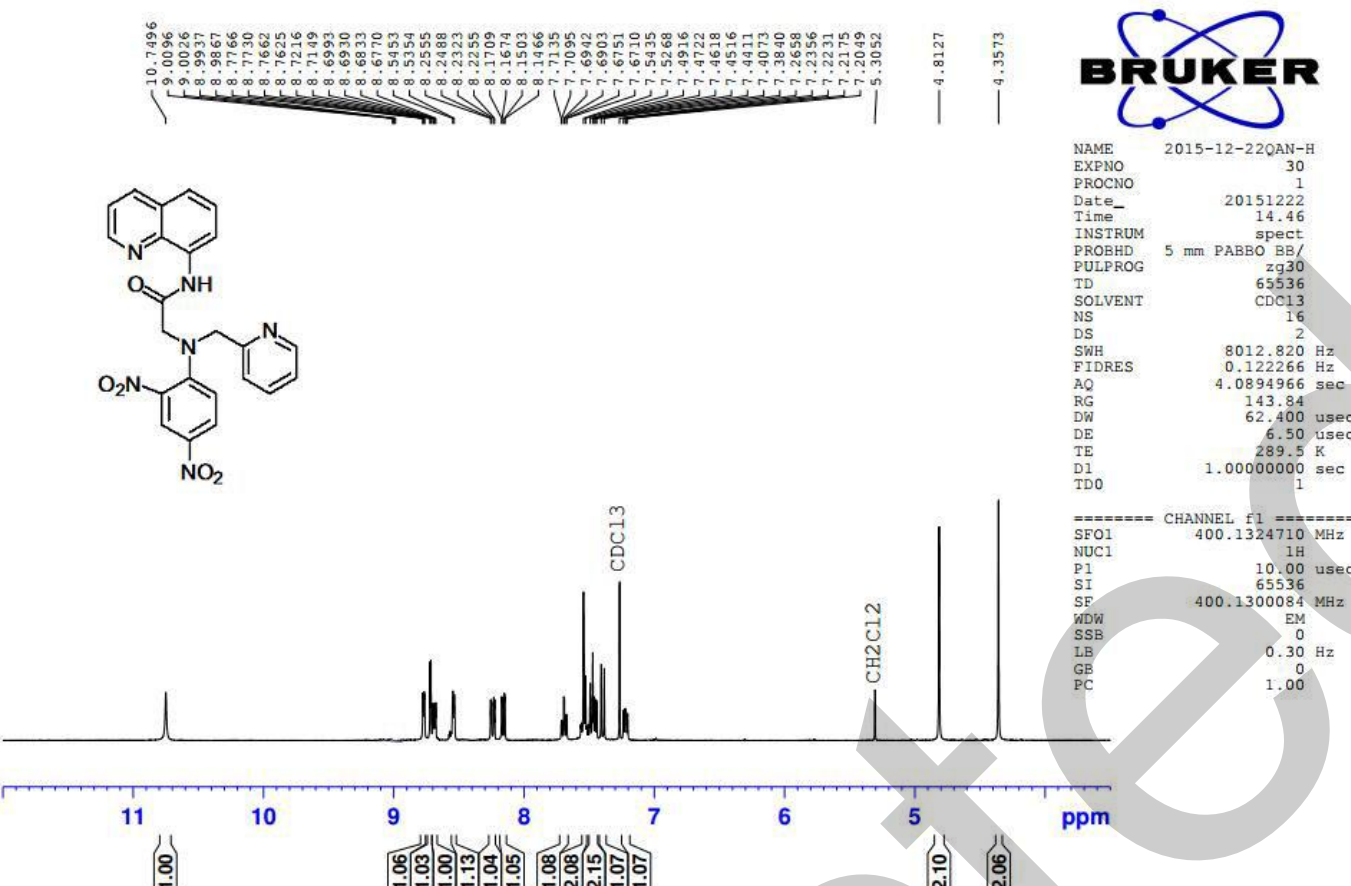

Figure S49. ${ }^{1} \mathrm{H}$ NMR spectrum of 2 in $\mathrm{CDCl}_{3}$.

QAN
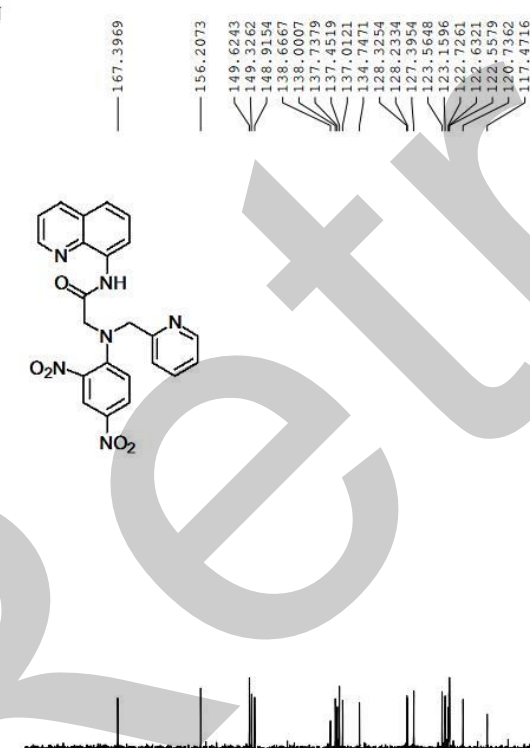

Figure S50. ${ }^{13} \mathrm{C}$ NMR spectrum of 2 in DMSO- $d_{6}$.

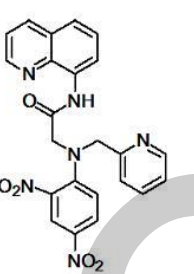

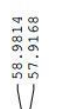
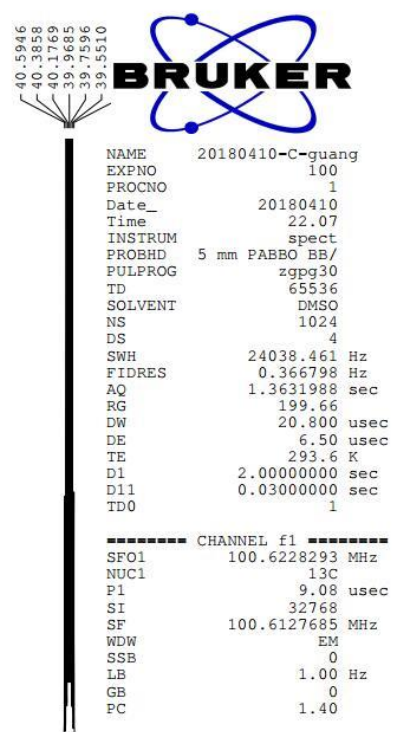


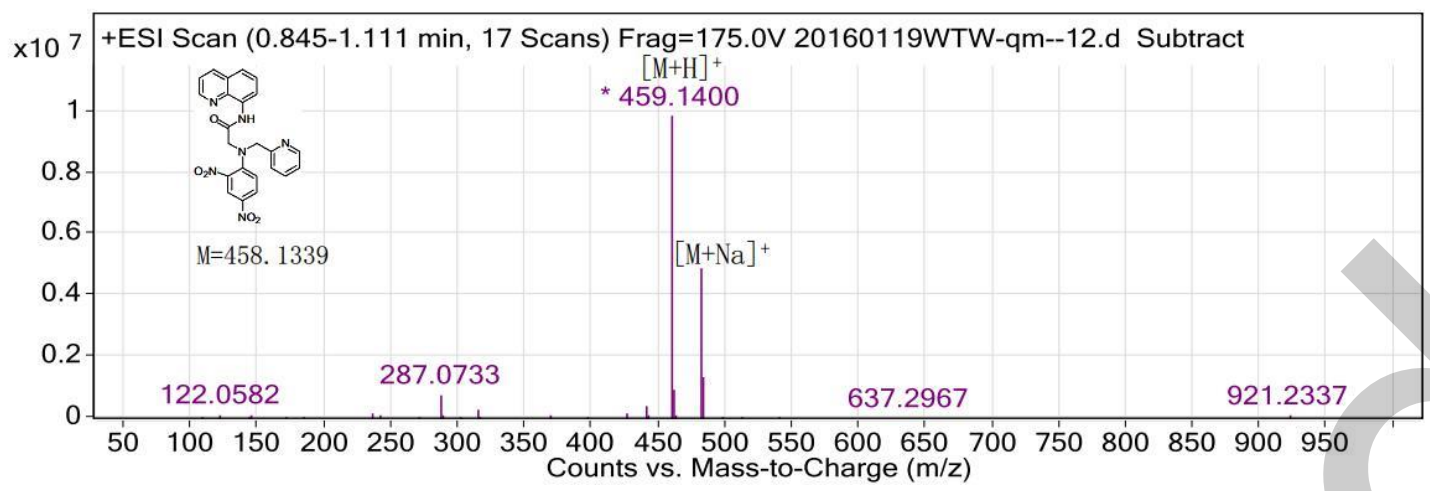

Figure S51. High resolution mass spectrometry of 2.

$\mathrm{QBN}$

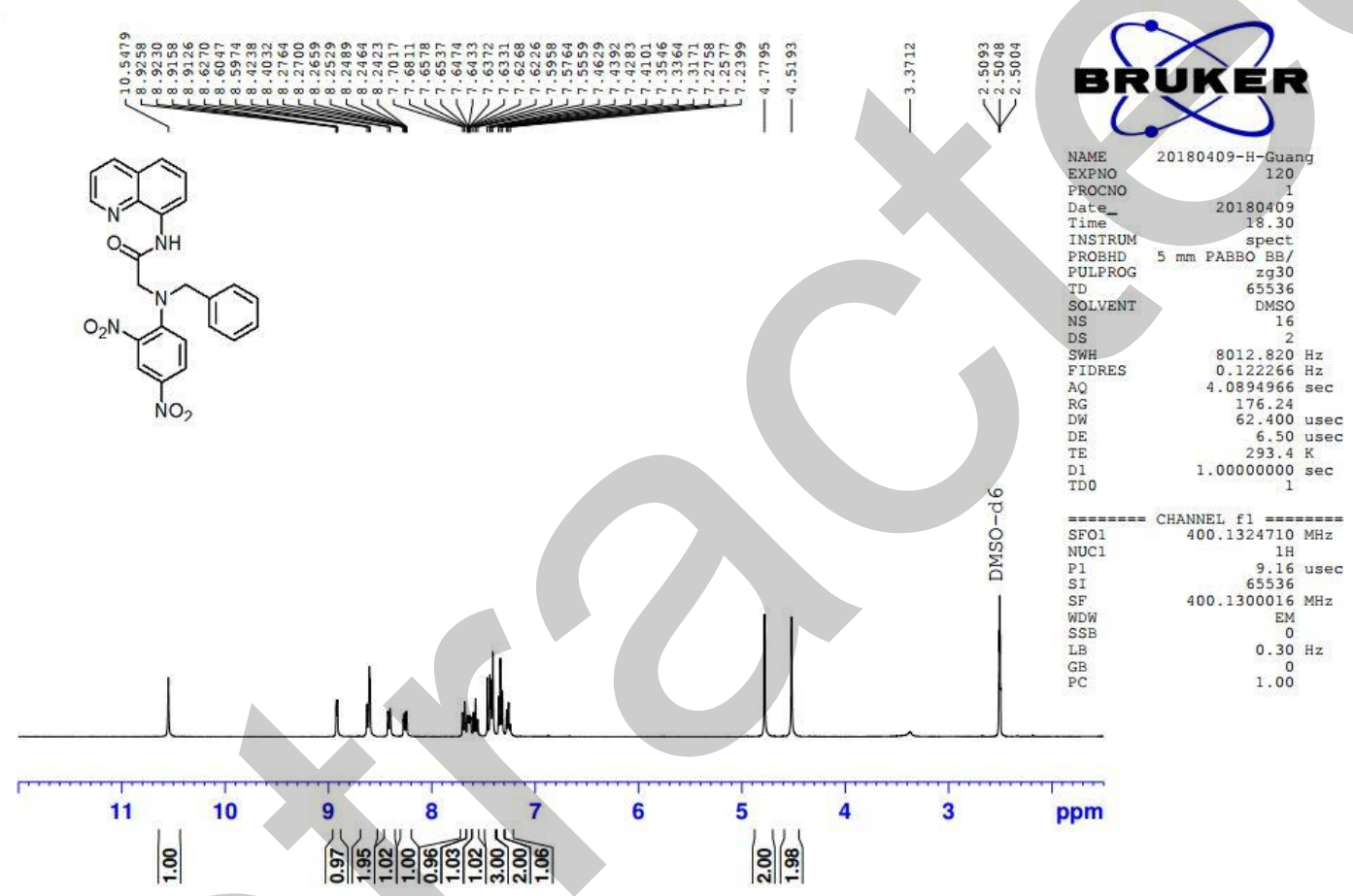

Figure S52. ${ }^{1} \mathrm{H}$ NMR spectrum of 3 in DMSO- $d_{6}$. 
QBN

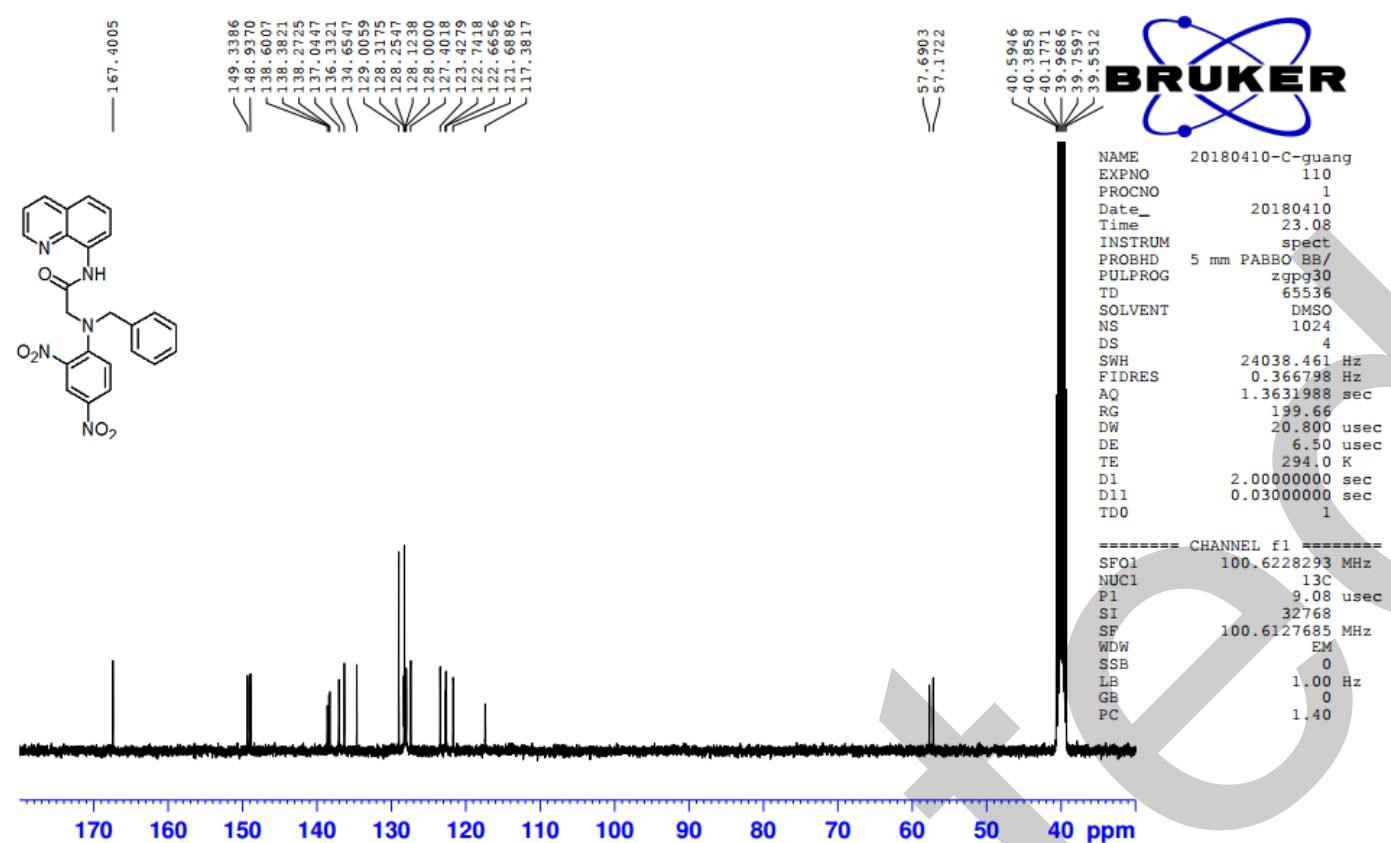

Figure 53. ${ }^{13} \mathrm{C}$ NMR spectrum of $\mathbf{3}$ in DMSO- $d_{6}$.

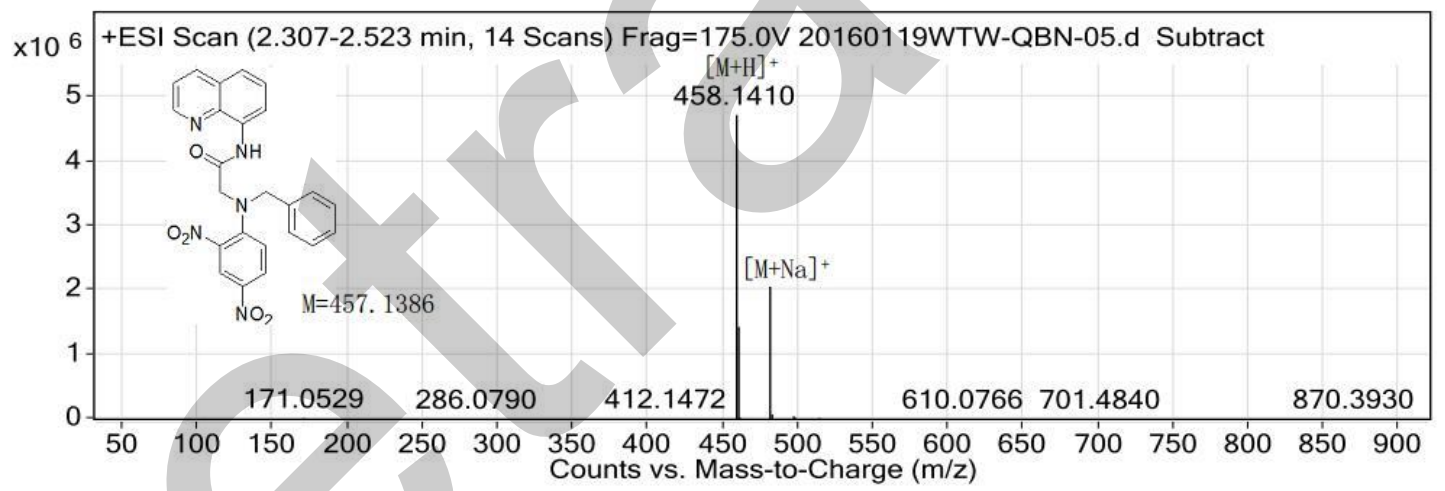

Figure S54. High resolution mass spectrometry of 3 . 


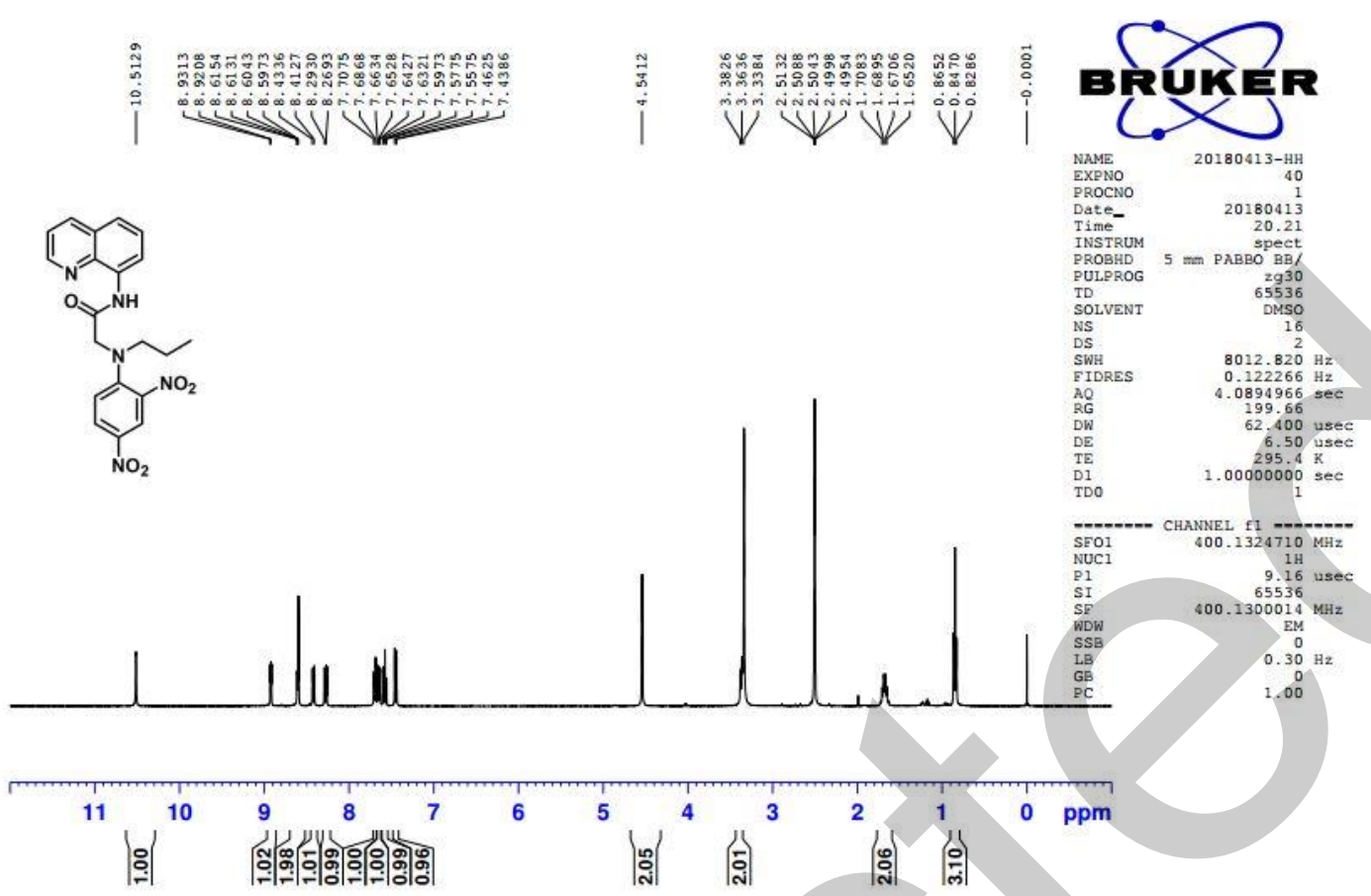

Figure S55. ${ }^{1} \mathrm{H}$ NMR spectrum of $\mathbf{4}$ in DMSO- $d_{6}$.
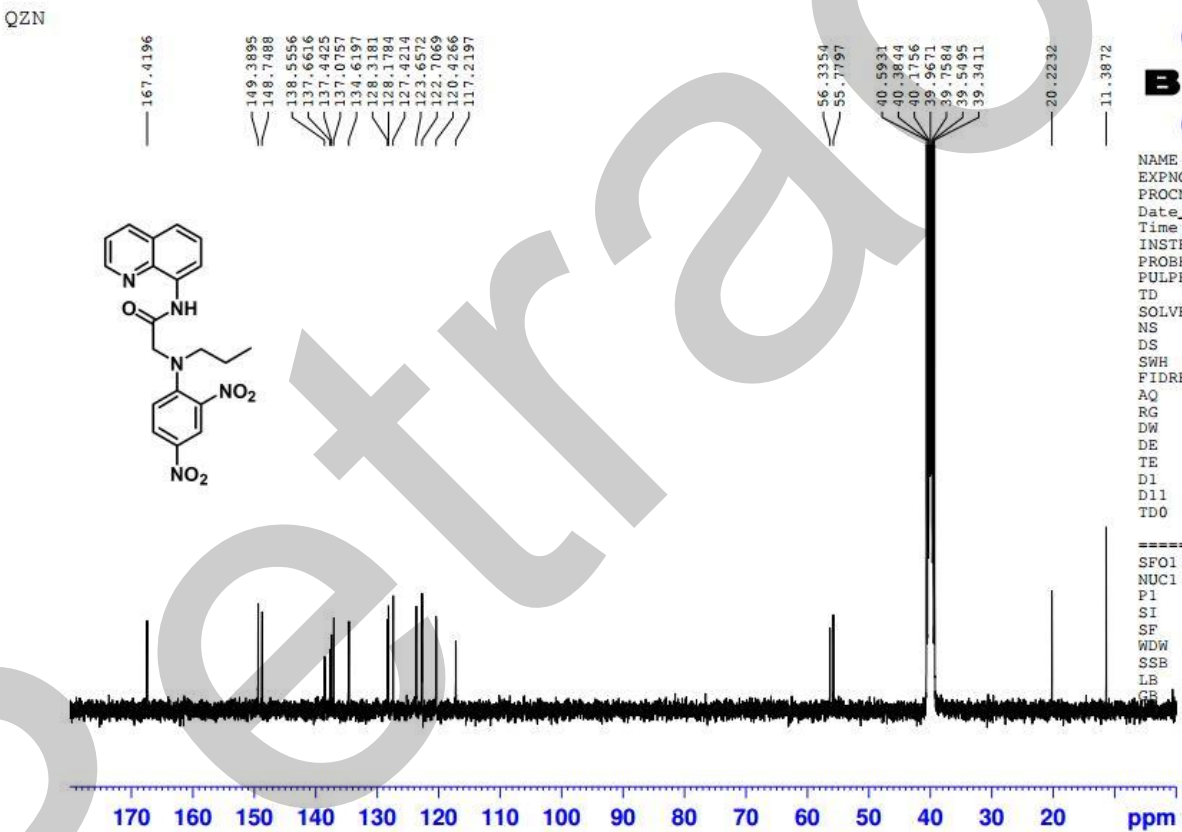

Figure $56 .{ }^{13} \mathrm{C}$ NMR spectrum of 4 in DMSO- $d_{6}$. 


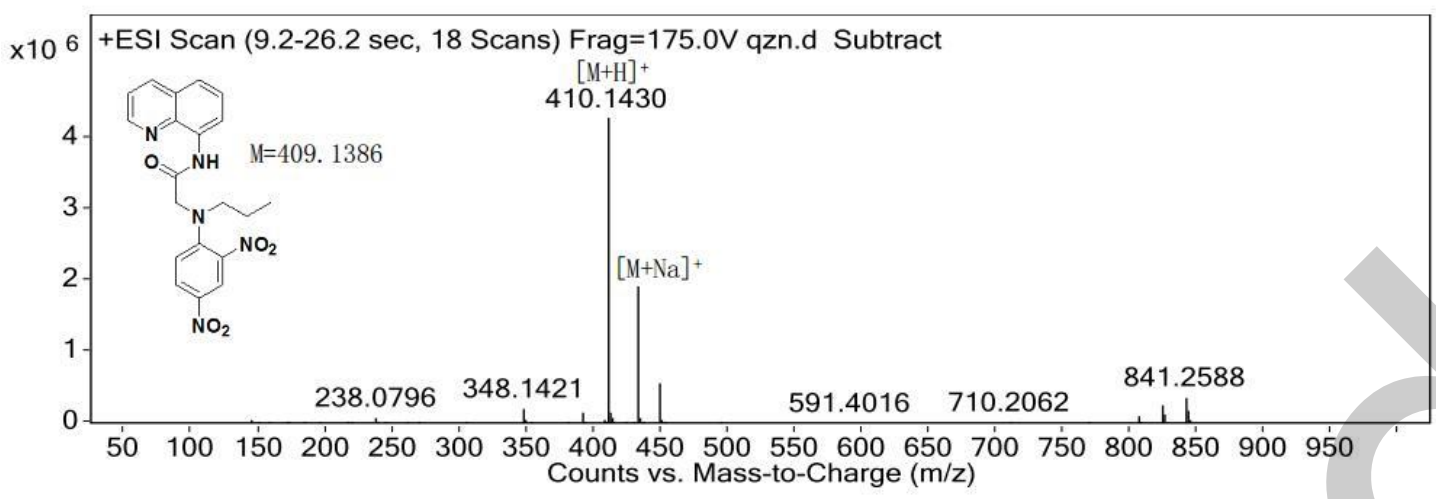

Figure S57. High resolution mass spectrometry of 4 .

AN

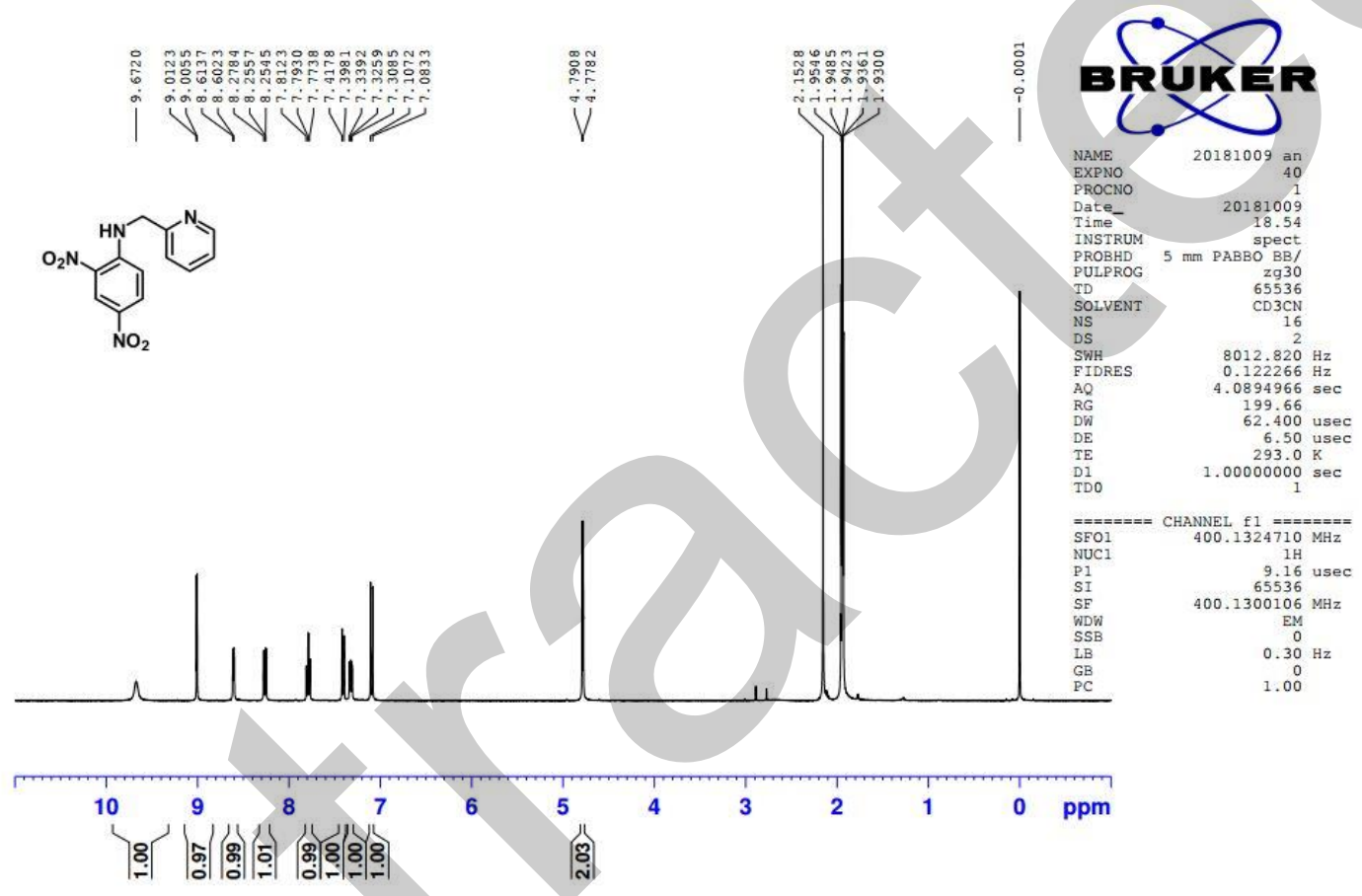

Figure S58. ${ }^{1} \mathrm{H}$ NMR spectrum of $\mathbf{2} \mathbf{i}$ in $\mathrm{CD}_{3} \mathrm{CN}$. 
AN

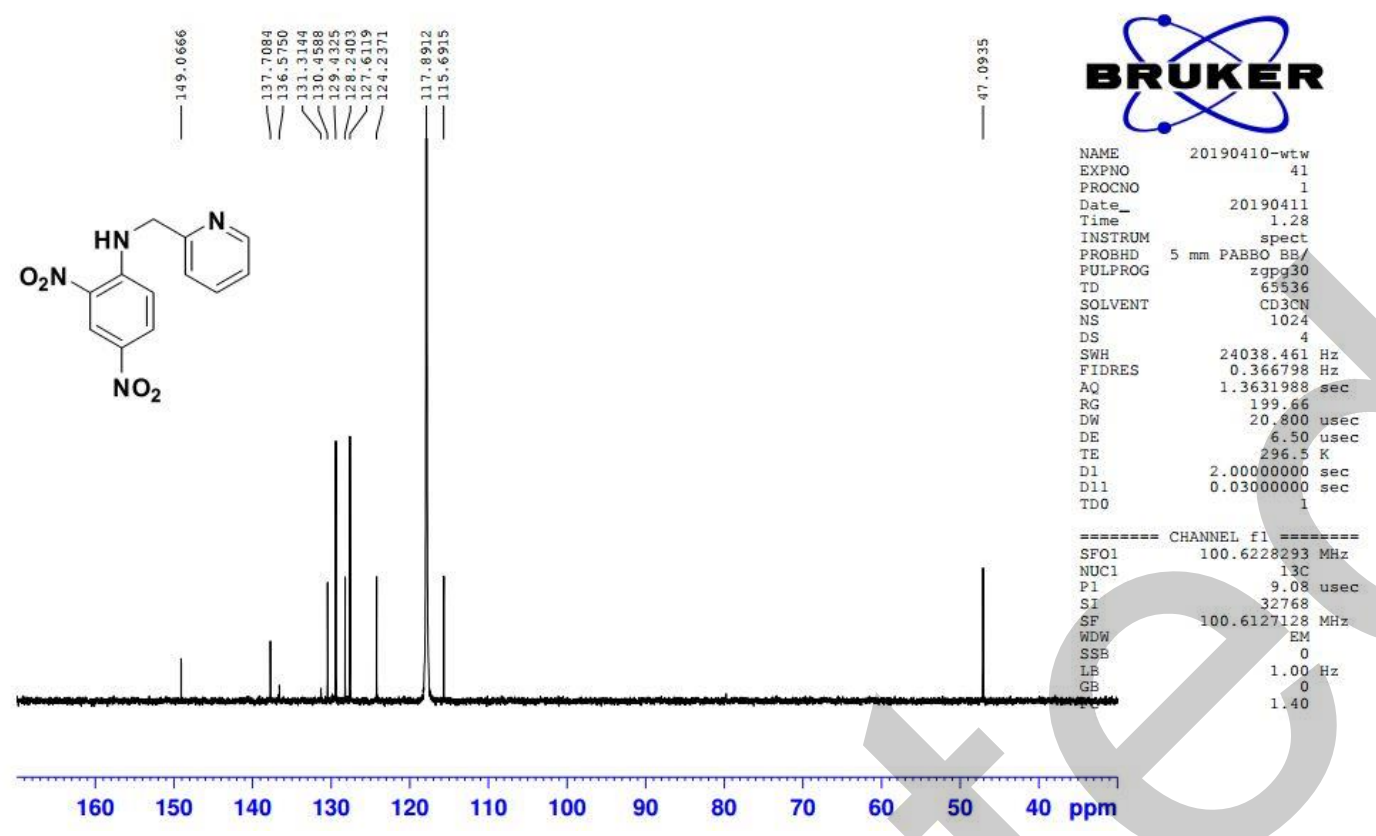

Figure S59. ${ }^{13} \mathrm{C}$ NMR spectrum of $2 \mathbf{i}$ in $\mathrm{CD}_{3} \mathrm{CN}$.

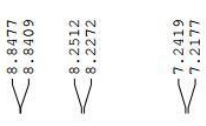
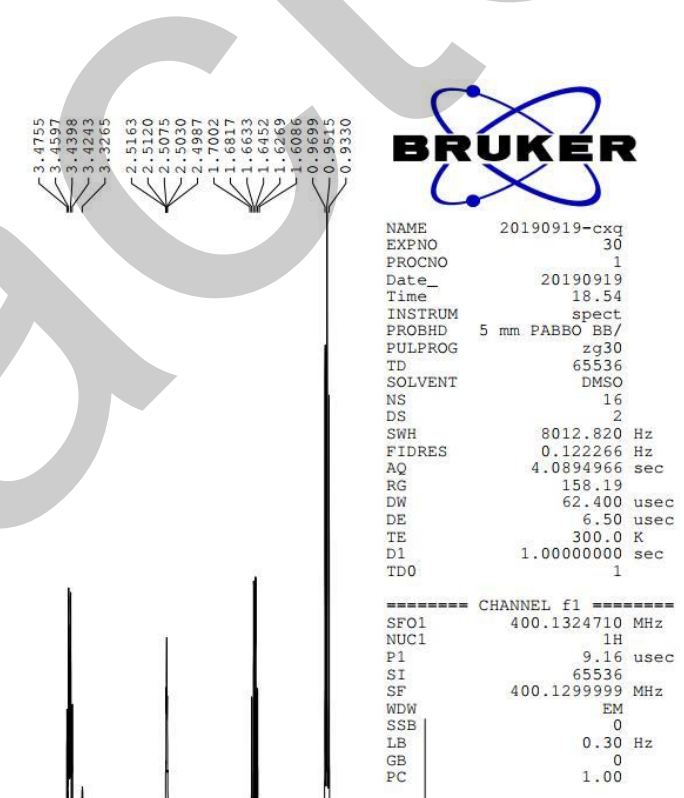

10

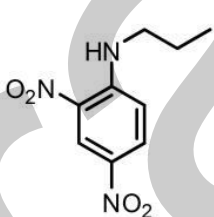

Figure S60. ${ }^{1} \mathrm{H}$ NMR spectrum of $4 \mathbf{i}$ in DMSO- $d_{6}$. 


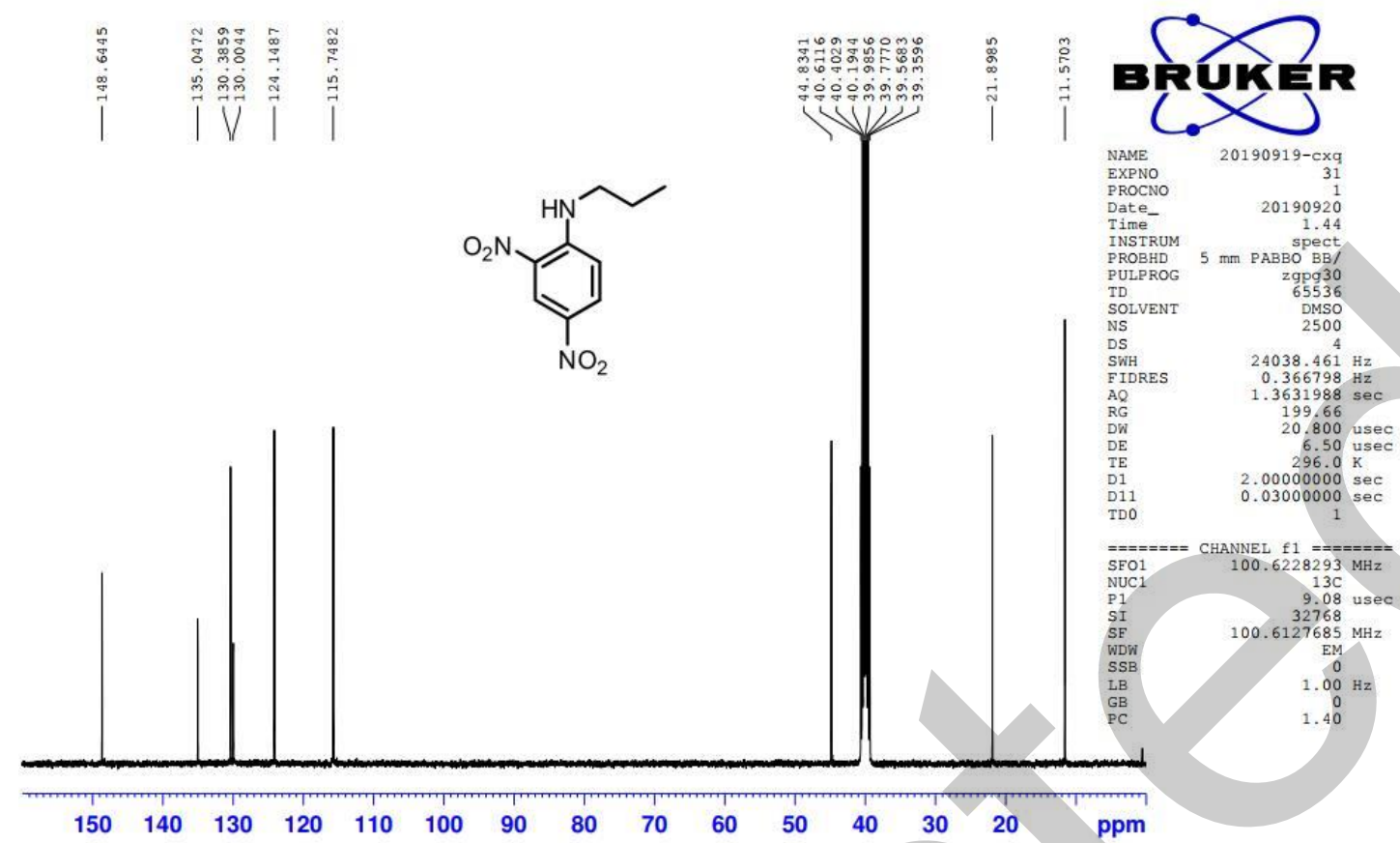

Figure S61. ${ }^{13} \mathrm{C}$ NMR spectrum of $4 \mathbf{i}$ in DMSO- $d_{6}$.

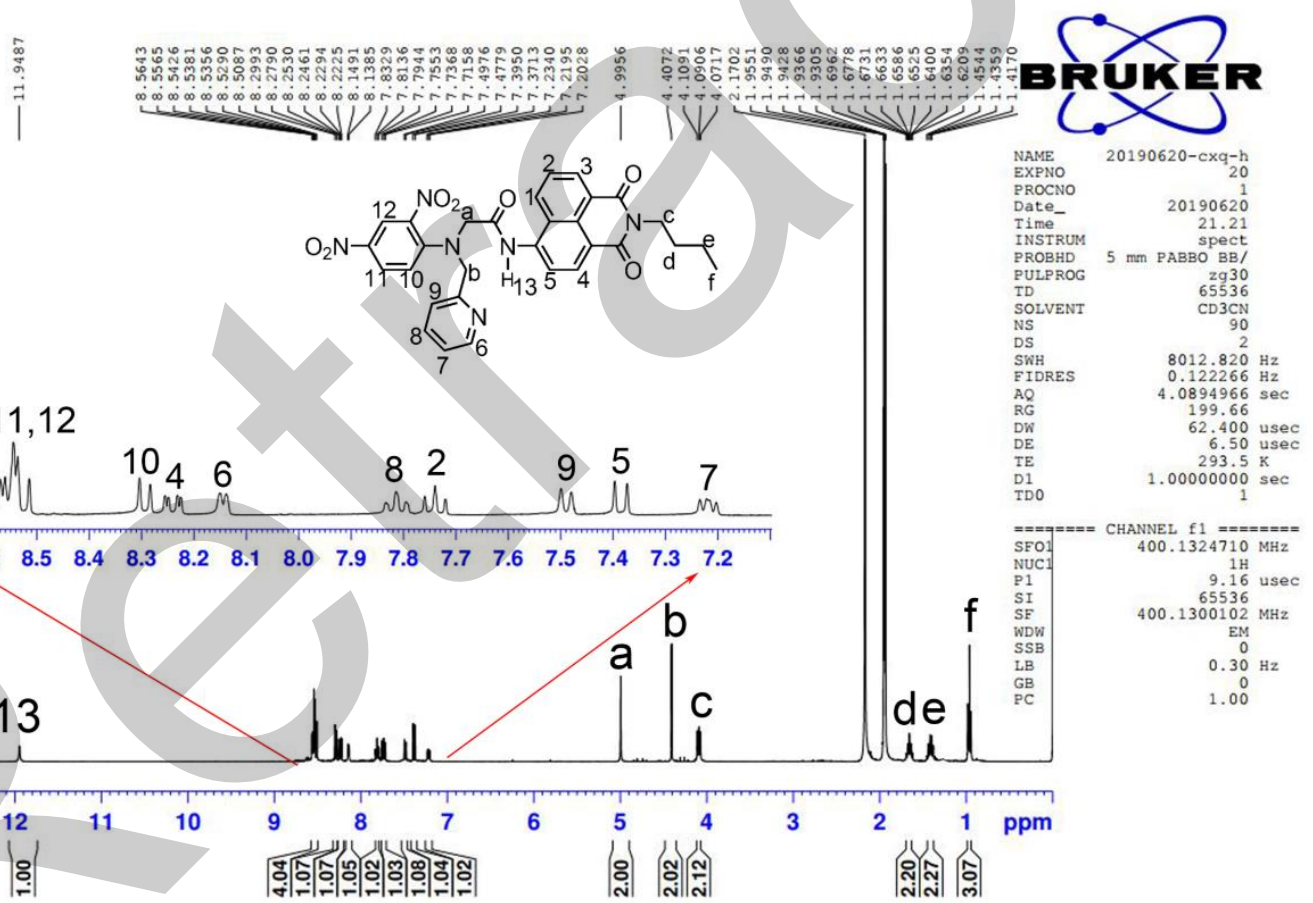

Figure S62. ${ }^{1} \mathrm{H}$ NMR spectrum of 5 in $\mathrm{CD}_{3} \mathrm{CN}$. 


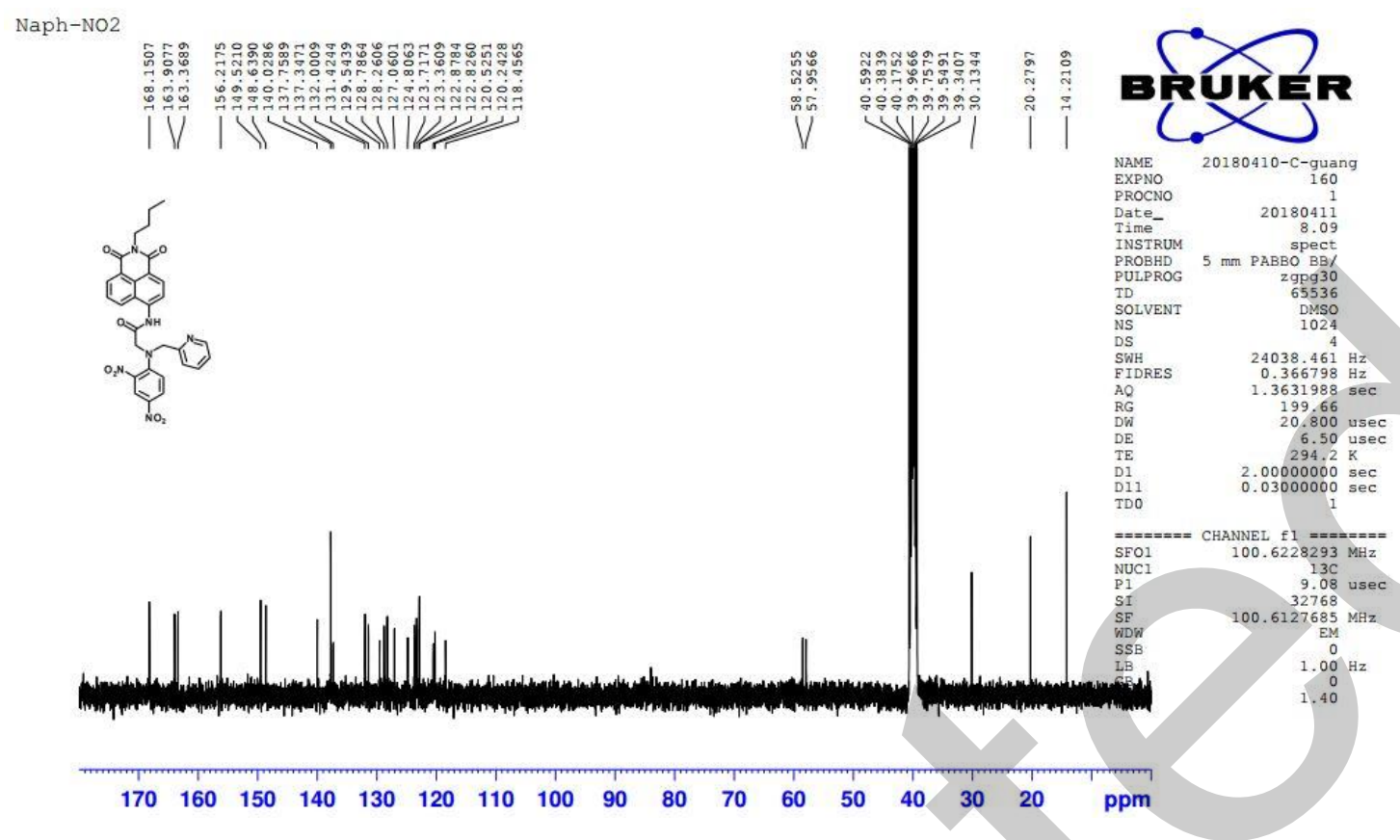

Figure S63. ${ }^{13} \mathrm{C}$ NMR spectrum of 5 in DMSO- $d_{6}$.

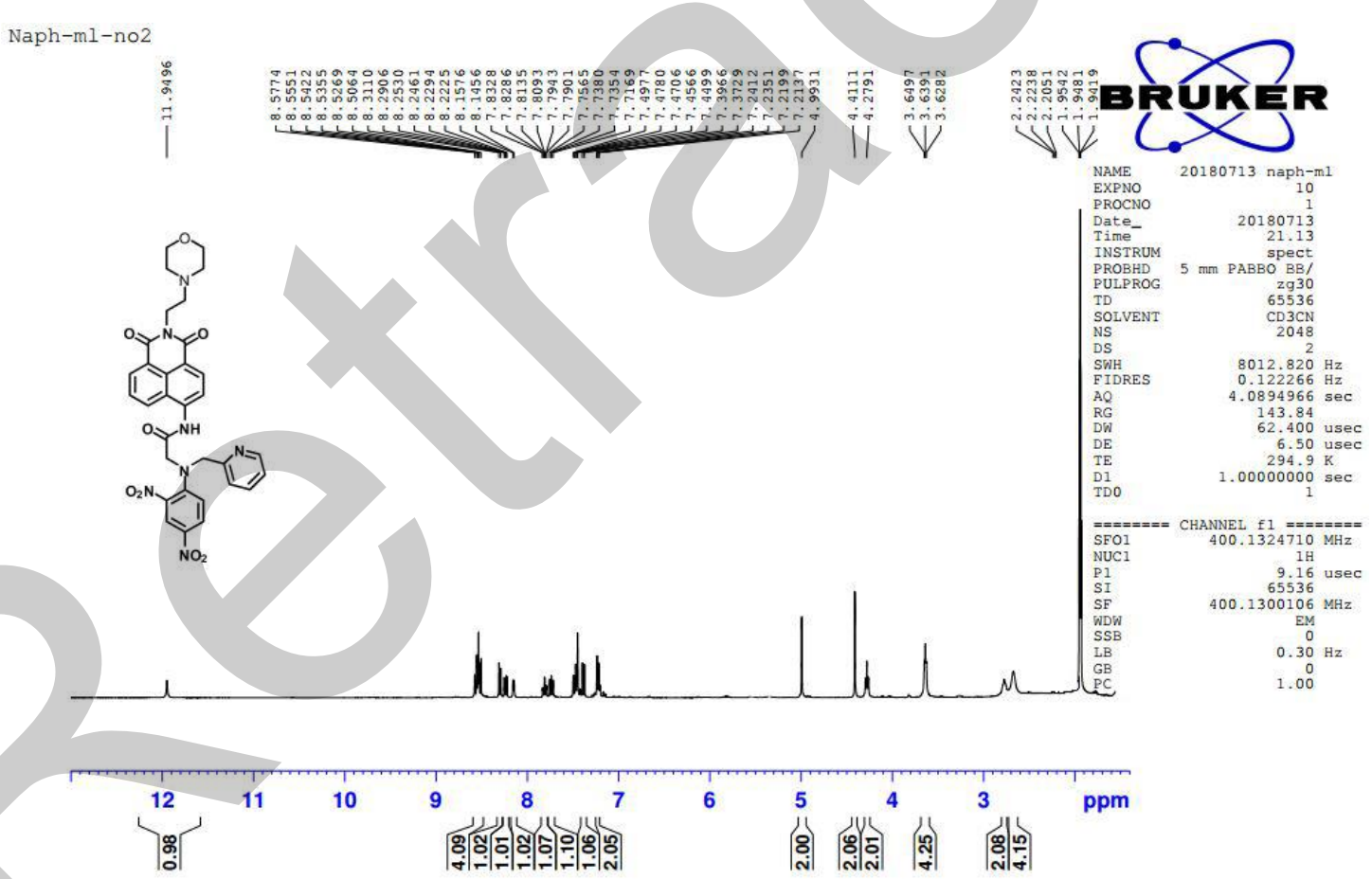

Figure S64. ${ }^{1} \mathrm{H}$ NMR spectrum of 6 in $\mathrm{CD}_{3} \mathrm{CN}$ 


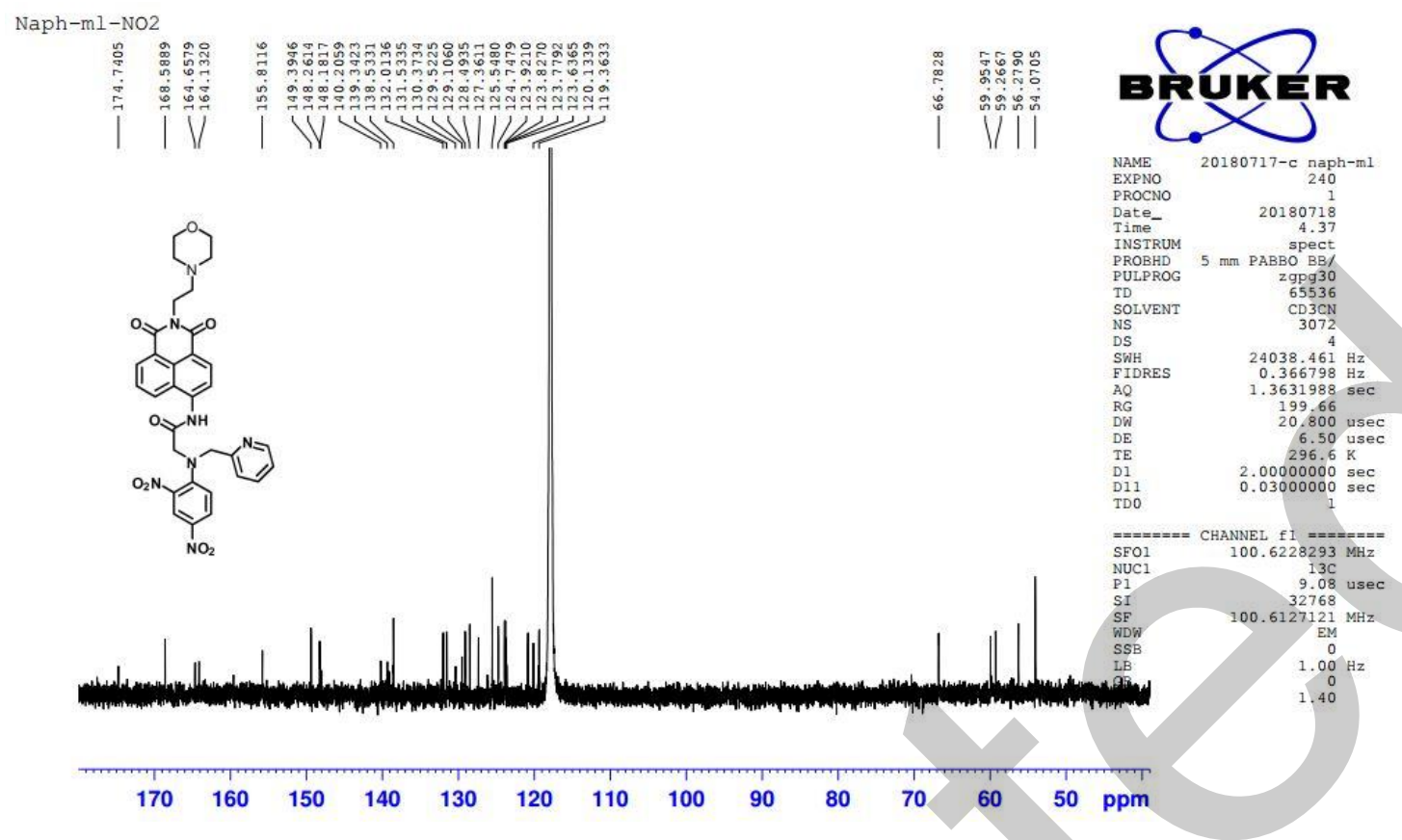

Figure S65. ${ }^{13} \mathrm{C}$ NMR spectrum of 6 in $\mathrm{CD}_{3} \mathrm{CN}$.

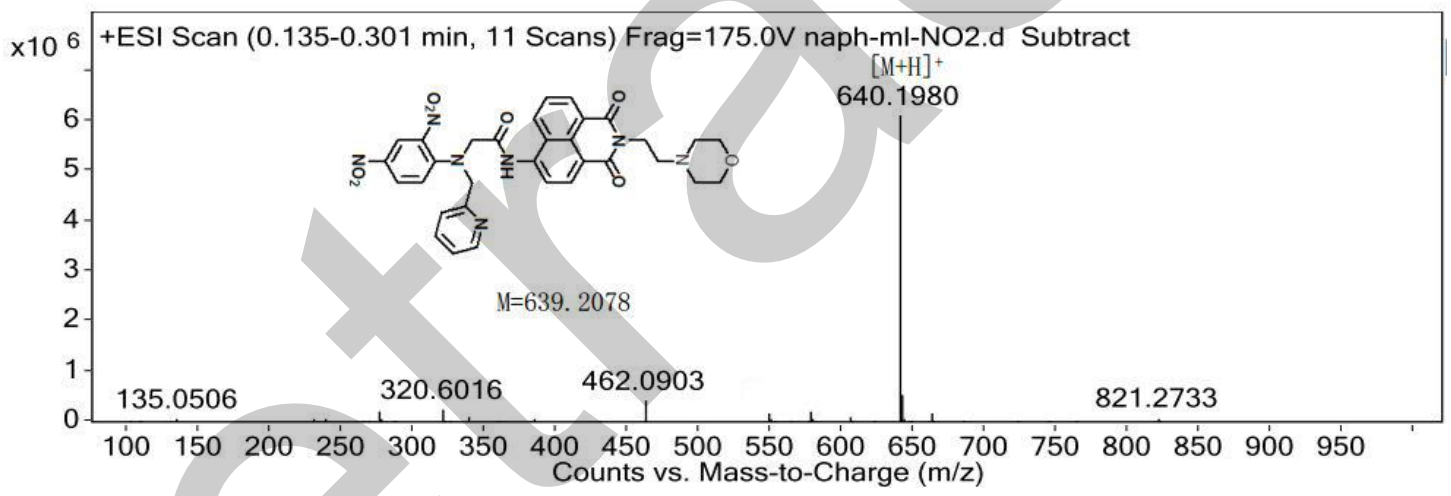

Figure S66. High resolution mass spectrometry of $\mathbf{6}$. 


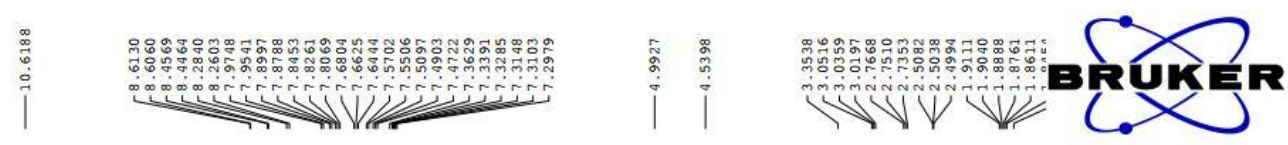

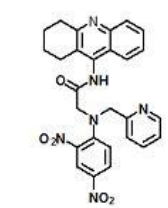

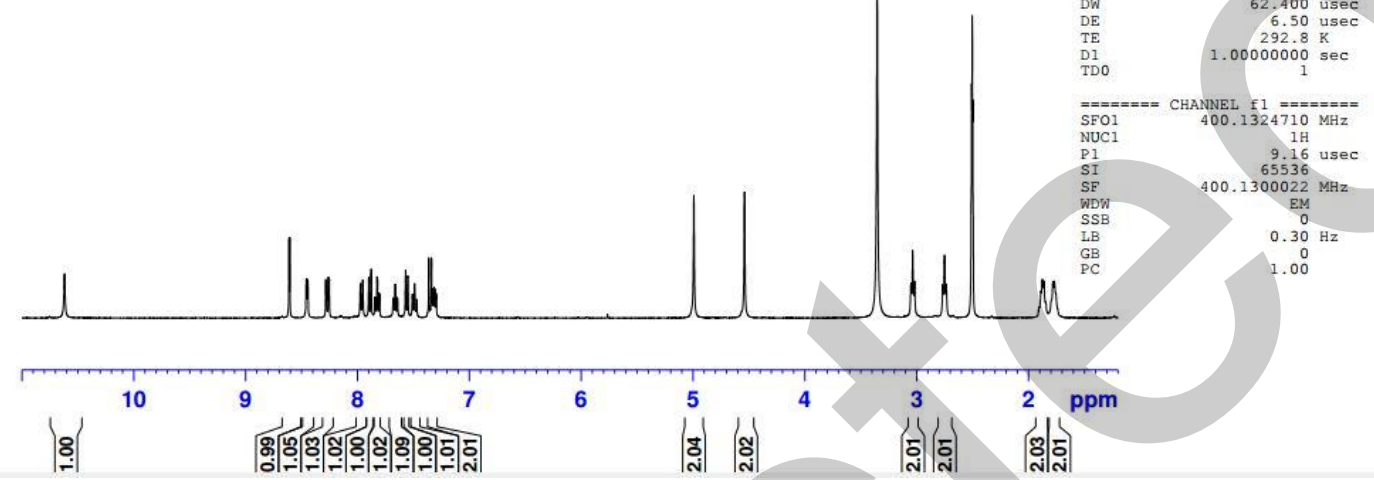

Figure S67. ${ }^{1} \mathrm{H}$ NMR spectrum of 7 in DMSO- $d_{6}$.

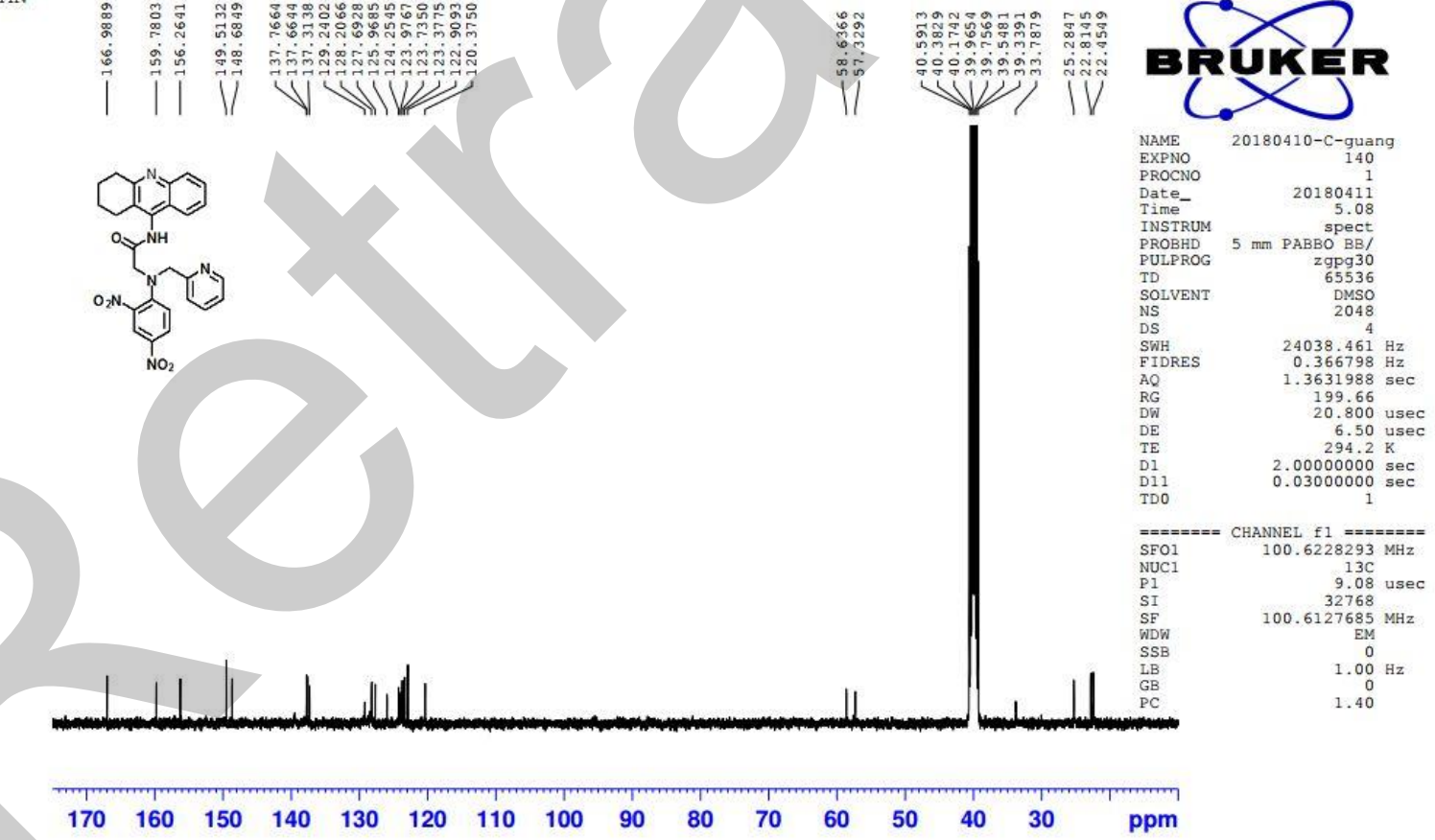

Figure S68. ${ }^{13} \mathrm{C}$ NMR spectrum of 7 in DMSO- $d_{6}$. 


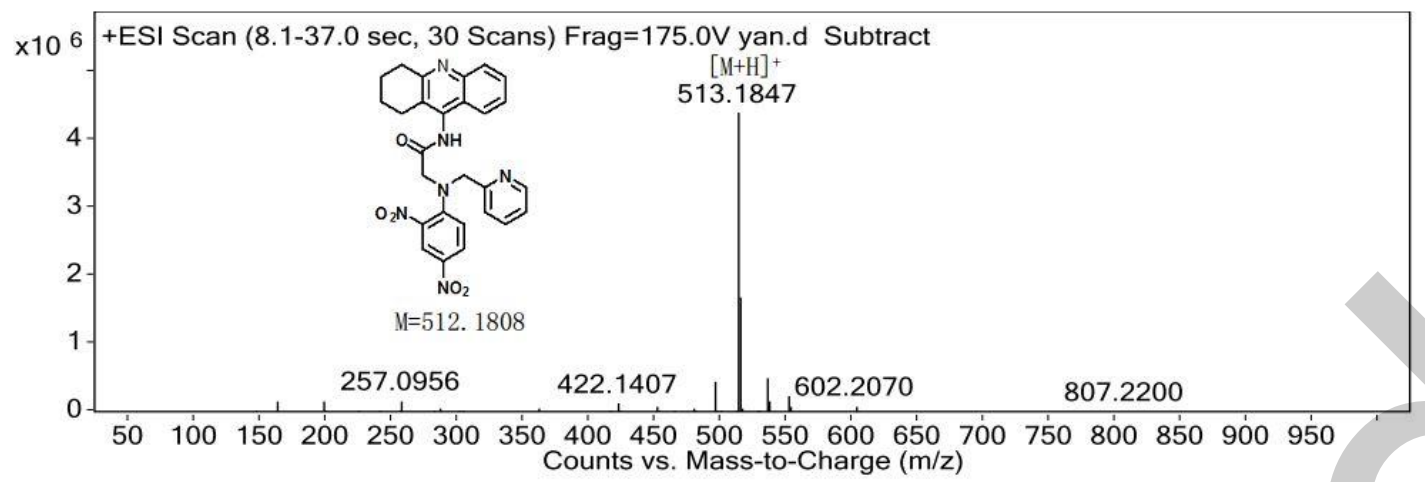

Figure S69. High resolution mass spectrometry of 7.

Table S2 Ground state minimum energy Cartesian coordinate of 2-G1.

\begin{tabular}{|c|c|c|c|}
\hline $\mathrm{C}$ & -3.266776 & -1.300490 & 0.344061 \\
\hline $\mathrm{C}$ & -4.098958 & -2.310962 & 0.789897 \\
\hline $\mathrm{C}$ & -5.494687 & -2.219791 & 0.585608 \\
\hline $\mathrm{C}$ & -6.064633 & -1.144468 & -0.052876 \\
\hline $\mathrm{C}$ & -4.860445 & 2.033224 & -1.601703 \\
\hline $\mathrm{C}$ & -3.479455 & 1.860189 & -1.358735 \\
\hline $\mathrm{C}$ & -1.043109 & -2.187035 & 1.055617 \\
\hline $\mathrm{C}$ & -3.831899 & -0.165659 & -0.329033 \\
\hline $\mathrm{C}$ & -5.239311 & -0.091378 & -0.522821 \\
\hline $\mathrm{C}$ & -5.734598 & & -1.185365 \\
\hline $\mathrm{O}$ & -1.420879 & -3.307046 & 1.429839 \\
\hline $\mathrm{N}$ & -1.883146 & -1.252183 & 0.498840 \\
\hline & & 0.804055 & -0.750081 \\
\hline & -3.675782 & -3.166994 & 1.290521 \\
\hline $\mathrm{H}$ & -6.121317 & -3.026960 & 0.946220 \\
\hline $\mathrm{H}$ & -7.136136 & -1.086928 & -0.203764 \\
\hline $\mathrm{H}$ & -5.209122 & 2.924238 & -2.108031 \\
\hline $\mathrm{H}$ & -2.770580 & 2.618789 & -1.675811 \\
\hline $\mathrm{H}$ & -6.801180 & 1.155641 & -1.354116 \\
\hline $\mathrm{N}$ & -0.181551 & 2.927025 & 1.761850 \\
\hline
\end{tabular}




\begin{tabular}{|c|c|c|c|}
\hline $\mathrm{O}$ & 6.702205 & -0.740873 & -1.299870 \\
\hline $\mathrm{H}$ & 2.652639 & 1.182962 & 2.131904 \\
\hline $\mathrm{H}$ & 4.443112 & -1.580742 & -1.564316 \\
\hline $\mathrm{H}$ & 4.997369 & 1.410824 & 1.467748 \\
\hline $\mathrm{H}$ & 0.350747 & 0.953829 & -0.919808 \\
\hline $\mathrm{H}$ & -0.561700 & 4.953173 & 1.740732 \\
\hline $\mathrm{H}$ & -0.423058 & 5.178148 & -0.734524 \\
\hline $\mathrm{H}$ & 0.051013 & 3.123174 & -2.095837 \\
\hline $\mathrm{H}$ & -0.785146 & 0.209302 & 2.136642 \\
\hline $\mathrm{C}$ & 0.354277 & -1.817011 & 1.168959 \\
\hline $\mathrm{C}$ & 2.184400 & -0.356695 & 0.693571 \\
\hline $\mathrm{C}$ & 2.722154 & -1.103226 & -0.387636 \\
\hline $\mathrm{C}$ & 4.056996 & -0.995677 & -0.743390 \\
\hline $\mathrm{C}$ & 4.864321 & -0.097532 & -0.059629 \\
\hline $\mathrm{C}$ & 4.353782 & 0.709408 & 0.957570 \\
\hline $\mathrm{C}$ & 3.028336 & 0.577553 & 1.321627 \\
\hline $\mathrm{C}$ & 0.201018 & 0.562014 & 1.840761 \\
\hline $\mathrm{C}$ & 0.066828 & 1.833485 & 1.030650 \\
\hline C & -0.357563 & 10 & 1.119516 \\
\hline $\mathrm{C}$ & -0.281020 & 4.213049 & -0.265236 \\
\hline C & -0.016714 & 3.072427 & -1.015755 \\
\hline & 0.155164 & 1.857513 & -0.359981 \\
\hline & 0.789693 & -1.280528 & -1.713983 \\
\hline $\mathrm{H}$ & 0.733328 & 0.776245 & 2.770145 \\
\hline$\Lambda$ & 1.905782 & -1.977812 & -1.167904 \\
\hline $\mathrm{N}$ & 0.870781 & -0.541418 & 1.126139 \\
\hline $\mathrm{N}$ & 6.264071 & 0.022799 & -0.439735 \\
\hline $\mathrm{O}$ & 6.944627 & 0.882883 & 0.118535 \\
\hline $\mathrm{H}$ & -1.483030 & -0.428515 & 0.059001 \\
\hline
\end{tabular}




$\begin{array}{llll}\mathrm{O} & 2.382505 & -2.916391 & -1.839747 \\ \mathrm{H} & 1.059593 & -2.633414 & 1.232341 \\ \mathrm{H} & 0.208117 & -1.989496 & -2.035050\end{array}$

Table S3 Excited state minimum energy Cartesian coordinate of 2-G1*.

C $\quad-3.416091 \quad-2.525021 \quad 0.808352$

C $\quad-4.820741 \quad-2.686562 \quad 0.812801$

C $\quad-5.648533 \quad-1.791024 \quad 0.179363$

C $\quad-5.245230 \quad 1.337483 \quad-1.818336$

C $\quad-3.835028 \quad 1.415300 \quad-1.778332$

C $\quad-0.456421 \quad-1.864054 \quad 0.576992$

C $\quad-3.687658 \quad-0.499975 \quad-0.522461$

$\begin{array}{llll}\text { C } & -5.097868 & -0.676064 & -0.502190\end{array}$

$\begin{array}{lllll}\text { C } & -5.873208 & 0.294557 & -1.181990\end{array}$

$\begin{array}{lllll}\text { O } & -0.484343 & -2.943845 & 1.144308\end{array}$

$\mathrm{N} \quad-1.487170 \quad-1.150064 \quad 0.093506$

$\mathrm{N} \quad-3.077846 \quad 0.534233-1.156007$

$\mathrm{H} \quad-2.785446 \quad-3.238389 \quad 1.315668$

$\mathrm{H} \quad \begin{array}{llll}-5.241264 & -3.538626 & 1.332402\end{array}$

$\begin{array}{llll}\mathrm{H} & -6.723799 & -1.924273 & 0.191346\end{array}$

\begin{tabular}{lll|l}
$\mathrm{H}$ & -5.808118 & 2.095757 & -2.347049
\end{tabular}

H $\quad-3.322643 \quad 2.232632 \quad-2.274493$

H $\quad-6.953079 \quad 0.201592 \quad-1.191663$

$\begin{array}{llll}\mathrm{N} & -1.498645 & 2.153919 & 1.786394\end{array}$

O $\quad 6.882288 \quad-0.954311 \quad-1.583123$

$\begin{array}{llll}\mathrm{H} & 3.234385 & 1.990632 & 1.675002\end{array}$

$\mathrm{H} \quad 4.625113 \quad-1.807101 \quad-1.329290$

$\begin{array}{llll}\mathrm{H} & 5.539780 & 1.845714 & 0.755498\end{array}$

$\begin{array}{llll}\mathrm{H} & 0.933659 & 2.027776 & -0.551025\end{array}$ 


\begin{tabular}{|c|c|c|c|}
\hline $\mathrm{H}$ & -3.177002 & 3.348224 & 1.746851 \\
\hline $\mathrm{H}$ & -2.621034 & 4.438226 & -0.419556 \\
\hline $\mathrm{H}$ & -0.516914 & 3.751262 & -1.600100 \\
\hline $\mathrm{H}$ & -0.205229 & 0.125890 & 2.480603 \\
\hline $\mathrm{C}$ & 0.875374 & -1.178522 & 0.417739 \\
\hline $\mathrm{C}$ & 2.647738 & 0.148821 & 0.683411 \\
\hline $\mathrm{C}$ & 3.044258 & -0.889187 & -0.145201 \\
\hline $\mathrm{C}$ & 4.327095 & -0.997680 & -0.684015 \\
\hline $\mathrm{C}$ & 5.210512 & 0.025679 & -0.323953 \\
\hline $\mathrm{C}$ & 4.811379 & 1.084207 & 0.518265 \\
\hline $\mathrm{C}$ & 3.523480 & 1.167372 & 1.036962 \\
\hline $\mathrm{C}$ & 0.454268 & 0.770015 & 1.902252 \\
\hline $\mathrm{C}$ & -0.374665 & 1.798917 & 1.155581 \\
\hline $\mathrm{C}$ & -2.268965 & 3.084783 & 1.214622 \\
\hline $\mathrm{C}$ & -1.958376 & 3.693369 & 0.001507 \\
\hline $\mathrm{C}$ & -0.793214 & 3.309310 & -0.650773 \\
\hline $\mathrm{C}$ & 0.018739 & 2.341640 & -0.065337 \\
\hline $\mathrm{O}$ & 1.854284 & -2.769446 & -1.006231 \\
\hline $\mathrm{H}$ & 1.134777 & & 2.604478 \\
\hline $\mathrm{N}$ & 1.928794 & -1.714169 & -0.300383 \\
\hline$\Lambda$ & 1.273911 & -0.071141 & 1.021230 \\
\hline & 6.544112 & 0.010462 & -0.815002 \\
\hline $\mathrm{O}$ & 7.352251 & 0.946796 & -0.482171 \\
\hline & -1.310946 & -0.286241 & -0.423089 \\
\hline
\end{tabular}

Table S4 Ground state minimum energy Cartesian coordinate of TS1.

$\begin{array}{llll}\text { C } & -2.683179 & -0.789901 & -0.311356 \\ \text { C } & -3.271917 & -1.480593 & 0.785684 \\ \text { C } & -4.644090 & -1.486761 & 0.956887 \\ \text { C } & -5.480277 & -0.823956 & 0.058141 \\ & & & \text { S52 }\end{array}$




\begin{tabular}{|c|c|c|c|}
\hline $\mathrm{C}$ & -5.173029 & 1.195701 & -3.047744 \\
\hline $\mathrm{C}$ & -3.775498 & 1.132778 & -3.178885 \\
\hline $\mathrm{C}$ & -0.314680 & -1.144884 & 0.309499 \\
\hline $\mathrm{C}$ & -3.546738 & -0.119591 & -1.278971 \\
\hline $\mathrm{C}$ & -4.949795 & -0.135573 & -1.059409 \\
\hline $\mathrm{C}$ & -5.766233 & 0.553022 & -1.983231 \\
\hline $\mathrm{O}$ & -0.300538 & -1.945724 & 1.212764 \\
\hline $\mathrm{N}$ & -1.365379 & -0.666864 & -0.475490 \\
\hline $\mathrm{N}$ & -2.979183 & 0.495572 & -2.326202 \\
\hline $\mathrm{H}$ & -2.622125 & -1.976487 & 1.490543 \\
\hline $\mathrm{H}$ & -5.073887 & -2.003375 & 1.804787 \\
\hline $\mathrm{H}$ & -6.552341 & -0.829404 & 0.209859 \\
\hline $\mathrm{H}$ & -5.759846 & 1.737552 & -3.777283 \\
\hline $\mathrm{H}$ & -3.287717 & 1.624855 & -4.013650 \\
\hline $\mathrm{H}$ & -6.840238 & 0.566993 & -1.843751 \\
\hline $\mathrm{N}$ & -1.393756 & 1.494074 & 1.981992 \\
\hline $\mathrm{O}$ & 6.828228 & -1.300762 & -2.212054 \\
\hline $\mathrm{H}$ & 3.895618 & 2.010780 & 1.349989 \\
\hline H & 4.426379 & & -2.049406 \\
\hline $\mathrm{H}$ & 6.118036 & 1.445053 & 0.418353 \\
\hline $\mathrm{H}$ & 0.164732 & 2.878165 & -0.666209 \\
\hline & -3.416694 & 1.542482 & 2.382142 \\
\hline & -4.015149 & 2.851742 & 0.354334 \\
\hline $\mathrm{H}$ & -2.180704 & 3.549085 & -1.208108 \\
\hline $\mathrm{H}$ & 0.932017 & 0.845686 & 2.437939 \\
\hline $\mathrm{C}$ & 0.836224 & -0.345768 & -0.348988 \\
\hline $\mathrm{C}$ & 2.891399 & 0.490387 & 0.160053 \\
\hline $\mathrm{C}$ & 3.064665 & -0.548644 & -0.798546 \\
\hline $\mathrm{C}$ & 4.303361 & -0.876024 & -1.325861 \\
\hline
\end{tabular}




\begin{tabular}{lrrr}
$\mathrm{C}$ & 5.392087 & -0.121175 & -0.858372 \\
$\mathrm{C}$ & 5.239440 & 0.906542 & 0.094789 \\
$\mathrm{C}$ & 3.998615 & 1.226104 & 0.614080 \\
$\mathrm{C}$ & 0.977946 & 1.405570 & 1.501596 \\
$\mathrm{C}$ & -0.419103 & 1.860842 & 1.141932 \\
$\mathrm{C}$ & -2.647757 & 1.861155 & 1.686338 \\
$\mathrm{C}$ & -2.982165 & 2.596633 & 0.553109 \\
$\mathrm{C}$ & -1.962148 & 2.979686 & -0.313567 \\
$\mathrm{C}$ & -0.657461 & 2.608277 & -0.015149 \\
$\mathrm{O}$ & 1.560766 & -2.087801 & -1.818773 \\
$\mathrm{H}$ & 1.627466 & 2.269562 & 1.648519 \\
$\mathrm{~N}$ & 1.823554 & -1.087580 & -1.039421 \\
$\mathrm{~N}$ & 1.575544 & 0.576038 & 0.455979 \\
$\mathrm{~N}$ & 6.699511 & -0.400225 & -1.360395 \\
$\mathrm{O}$ & 7.671849 & 0.256878 & -0.937485 \\
$\mathrm{H}$ & -0.414232 & 0.006354 & -1.063587 \\
\hline & & &
\end{tabular}

Table S5 Ground state minimum energy Cartesian coordinate of TS2.

\begin{tabular}{|c|c|c|c|}
\hline $\mathrm{C}$ & -2.44575900 & -1.55662400 & 0.03033000 \\
\hline $\mathrm{C}$ & 27768400 & -2.78345100 & 0.66244000 \\
\hline & 37583600 & -3.57306000 & 1.05907700 \\
\hline & -4.66581800 & -3.14710500 & 0.85011600 \\
\hline & -6.36807300 & -0.18352800 & -0.62071300 \\
\hline & -5.21447800 & 0.53506700 & -1.00797200 \\
\hline $\mathrm{C}$ & -0.24686200 & -0.74878800 & 0.16195500 \\
\hline C & -3.79187200 & -1.09303800 & -0.20682000 \\
\hline $\mathrm{C}$ & -4.89553400 & -1.89988100 & 0.21839900 \\
\hline $\mathrm{C}$ & -6.20165600 & -1.40114200 & -0.01119000 \\
\hline $\mathrm{O}$ & 0.20555000 & -1.26275900 & 1.20468400 \\
\hline $\mathrm{N}$ & -1.40384500 & -0.76448700 & -0.44608000 \\
\hline & & S54 & \\
\hline
\end{tabular}




\begin{tabular}{|c|c|c|c|}
\hline $\mathrm{N}$ & -3.98243800 & 0.10987300 & -0.81691600 \\
\hline $\mathrm{H}$ & -1.27399200 & -3.13865200 & 0.84914900 \\
\hline $\mathrm{H}$ & -3.18998000 & -4.52645400 & 1.54099500 \\
\hline $\mathrm{H}$ & -5.51352200 & -3.74623400 & 1.16279000 \\
\hline $\mathrm{H}$ & -7.35187500 & 0.22812400 & -0.80885900 \\
\hline $\mathrm{H}$ & -5.32312400 & 1.50078300 & -1.49563600 \\
\hline $\mathrm{H}$ & -7.05516300 & -1.99233700 & 0.30261300 \\
\hline $\mathrm{N}$ & -1.55600800 & 2.56785100 & 1.31018600 \\
\hline $\mathrm{O}$ & 6.76061100 & -1.90709400 & -0.97361700 \\
\hline $\mathrm{H}$ & 3.65647500 & 1.89950700 & 1.90866800 \\
\hline $\mathrm{H}$ & 4.40250700 & -1.73662500 & -1.51860600 \\
\hline $\mathrm{H}$ & 5.87491800 & 0.87235700 & 1.57631700 \\
\hline $\mathrm{H}$ & 0.68728600 & 3.38960600 & -1.06899300 \\
\hline $\mathrm{H}$ & -3.53826400 & 3.12846500 & 1.37809800 \\
\hline $\mathrm{H}$ & -3.48085300 & 4.41226100 & -0.75105500 \\
\hline $\mathrm{H}$ & -1.31246400 & 4.55544300 & -2.00667500 \\
\hline $\mathrm{H}$ & 0.40005400 & 1.27462900 & 2.06431600 \\
\hline $\mathrm{C}$ & 0.73271400 & 0.17133400 & -0.60664800 \\
\hline $\mathrm{C}$ & & 0.66967700 & 0.35594600 \\
\hline $\mathrm{C}$ & 2.98099900 & -0.37273500 & -0.59115300 \\
\hline $\mathrm{C}$ & 4.24075400 & -0.95634300 & -0.78961600 \\
\hline $\mathrm{C}$ & 5.23876400 & -0.47159600 & 0.01088500 \\
\hline $\mathrm{C}$ & 5.03037600 & 0.55349500 & 0.98242600 \\
\hline $\mathrm{C}$ & 3.80096000 & 1.12561400 & 1.16963100 \\
\hline $\mathrm{C}$ & 0.76273200 & 1.90430300 & 1.24991200 \\
\hline $\mathrm{C}$ & -0.40562600 & 2.63889700 & 0.63130300 \\
\hline $\mathrm{C}$ & -2.61879400 & 3.20641800 & 0.80747400 \\
\hline $\mathrm{C}$ & -2.58625200 & 3.92634500 & -0.38316200 \\
\hline $\mathrm{C}$ & -1.38332300 & 4.00047400 & -1.07918200 \\
\hline
\end{tabular}




$\begin{array}{lrrr}\mathrm{C} & -0.26851400 & 3.35051700 & -0.56039200 \\ \mathrm{O} & 1.60214800 & -1.45546700 & -2.11981400 \\ \mathrm{H} & 1.49134500 & 2.61081800 & 1.64821300 \\ \mathrm{~N} & 1.80727700 & -0.64373300 & -1.21853800 \\ \mathrm{~N} & 1.46265400 & 1.05935700 & 0.27706900 \\ \mathrm{~N} & 6.58737900 & -1.03709700 & -0.12855100 \\ \mathrm{O} & 7.46463200 & -0.60422600 & 0.61028600 \\ \mathrm{H} & 0.19364400 & 0.69322000 & -1.39213200\end{array}$

Table S6 Ground state minimum energy Cartesian coordinate of 2-G2 and 2-G3 .

$\begin{array}{lrrr}\mathrm{C} & 2.684999 & -1.239390 & -0.561444 \\ \mathrm{C} & 3.443934 & -0.936534 & -1.671537 \\ \mathrm{C} & 4.770382 & -0.481002 & -1.525921 \\ \mathrm{C} & 5.329714 & -0.334051 & -0.280217 \\ \mathrm{C} & 4.286210 & -0.793842 & 3.266460 \\ \mathrm{C} & 2.970319 & -1.248976 & 3.028065 \\ \mathrm{C} & 0.304845 & -1.535622 & -1.171151 \\ \mathrm{C} & 3.233771 & -1.107904 & 0.748670 \\ \mathrm{C} & 4.575406 & -0.641962 & 0.878852 \\ \mathrm{C} & 5.084404 & -0.492003 & 2.191379 \\ \mathrm{O} & -0.751385 & -1.509315 & -1.682379 \\ \mathrm{~N} & 1.381895 & -1.707122 & -0.682080 \\ \mathrm{~N} & 2.453743 & -1.402350 & 1.824104 \\ \mathrm{H} & 3.009539 & -1.044039 & -2.656830 \\ \mathrm{H} & 5.341646 & -0.238819 & -2.413401 \\ \mathrm{H} & 6.346541 & 0.022774 & -0.166471 \\ \mathrm{H} & 4.642352 & -0.687932 & 4.282989 \\ \mathrm{H} & 2.321947 & -1.487952 & 3.866013 \\ \mathrm{H} & 6.099022 & -0.136115 & 2.329224\end{array}$




\begin{tabular}{|c|c|c|c|}
\hline $\mathrm{N}$ & 0.560309 & 1.482271 & -1.077577 \\
\hline $\mathrm{O}$ & -6.659154 & -0.822244 & -0.579620 \\
\hline $\mathrm{H}$ & -2.240824 & 2.637811 & 0.349075 \\
\hline $\mathrm{H}$ & -4.567738 & -1.820717 & 0.132322 \\
\hline $\mathrm{H}$ & -4.632901 & 2.470382 & -0.307884 \\
\hline $\mathrm{H}$ & 2.798551 & 2.142702 & 1.350843 \\
\hline $\mathrm{H}$ & 0.831147 & 1.742865 & -3.105438 \\
\hline $\mathrm{H}$ & 3.131678 & 2.667755 & -2.905571 \\
\hline $\mathrm{H}$ & 4.145039 & 2.872299 & -0.618685 \\
\hline $\mathrm{H}$ & -0.239713 & 2.087786 & 1.739617 \\
\hline $\mathrm{C}$ & -0.646318 & -1.130646 & 1.157935 \\
\hline $\mathrm{C}$ & -2.075046 & 0.491084 & 0.626284 \\
\hline $\mathrm{C}$ & -2.739686 & -0.752295 & 0.561085 \\
\hline $\mathrm{C}$ & -4.064558 & -0.867384 & 0.186709 \\
\hline $\mathrm{C}$ & -4.706310 & 0.328634 & -0.115615 \\
\hline $\mathrm{C}$ & -4.069583 & 1.584702 & -0.054823 \\
\hline $\mathrm{C}$ & -2.740682 & 1.679927 & 0.315499 \\
\hline $\mathrm{C}$ & 0.250923 & 1.203077 & 1.327472 \\
\hline $\mathrm{C}$ & 1.102239 & & 0.135729 \\
\hline $\mathrm{C}$ & 1.294850 & 1.862769 & -2.131538 \\
\hline $\mathrm{C}$ & 2.580147 & 2.380079 & -2.019773 \\
\hline & 3.138798 & 2.494479 & -0.749482 \\
\hline & 2.390683 & 2.090983 & 0.348786 \\
\hline $\mathrm{O}$ & -2.054883 & -3.018962 & 0.973875 \\
\hline $\mathrm{H}$ & 0.877596 & 0.788085 & 2.114692 \\
\hline $\mathrm{N}$ & -1.809986 & -1.736330 & 0.927458 \\
\hline $\mathrm{N}$ & -0.788747 & 0.227755 & 1.022546 \\
\hline $\mathrm{N}$ & -6.108345 & 0.276236 & -0.519992 \\
\hline $\mathrm{O}$ & -6.679111 & 1.333745 & -0.783325 \\
\hline
\end{tabular}




\section{References}

(1) Cho, H.-J.; Um, I.-H. The $\alpha$-Effect in SNAr Reaction of 1-Fluoro-2,4-dinitrobenzene with Hydrazine: Ground-State Destabilization versus Transition-State Stabilization. Bulletin of the Korean Chemical Society 2014, 35 (8), 2371-2374.

(2) Lv, Y.; Zhang, Y.; Du, Y.; Xu, J.; Wang, J., A novel porphyrin-containing polyimide nanofibrous membrane for colorimetric and fluorometric detection of pyridine vapor. Sensors 2013, 13 (11), 15758-15769.

(3) Gazitúa, M.; Tapia, R. A.; Contreras, R.; Campodónico, P. R., Effect of the nature of the nucleophile and solvent on an SNAr reaction. New Journal of Chemistry 2018, 42 (1), 260-264.

(4) Ma, Y.; Wang, F.; Kambam, S.; Chen, X. A quinoline-based fluorescent chemosensor for distinguishing cadmium from zinc ions using cysteine as an auxiliary reagent. Sensor. Actuat. B-Chem. 2013, 188, 1116-1122.

(5) Zhaochao Xu; Kyung-Hwa Baek; Ha Na Kim; Jingnan Cui; Qian, X.; David R. Spring; Injae Shin; Yoon, J. $\mathrm{Zn}^{2+}$-Triggered Amide Tautomer-ization Produces a Highly $\mathrm{Zn}^{2+}$-Selective, Cell-Permeable, and Ratiometric Fluorescent Sensor. J. Am. Chem. Soc. 2010, 132, 601-610.

(6) Zhou, J.; Shi, W.; Li, L.; Gong, Q.; Wu, X.; Li, X.; Ma, H. Detection of Misdistribution of Tyrosinase from Melanosomes to Lysosomes and Its Upregulation under Psoralen/Ultraviolet A with a Melanosome-Targeting Tyrosinase Fluorescent Probe. Anal. Chem. 2016, 88 (8), 4557-4564.

(7) J. Frisch, G. W. Trucks, H. B. Schlegel, G. E. Scuseria, M. A. Robb, J. R. Cheeseman, G. Scalmani and V. Barone, et al., Gaussian 09, revision A.2, Gaussian, Inc., Wallingford, CT, 2009.

(8) Keld L. Bak; JOrgensen, P. Gauge-origin independent multiconfigurational self-consistent-field theory for vibrational circular dichroism. J. Chem. Phys. 1993, 98 (11), 8873-8886.

(9) Denis J.; Perpete, E. A.; Gustavo E. S.; Ilaria C.; Adamo, C. TD-DFT Performance for the Visible Absorption Spectra of Organic Dyes: Conventional versus Long-Range Hybrids. J. Chem. Theory Comput. 2008, 4, 123-135.

(10) Becke, A. D. Density-functional thermochemistry. III.The role of exact exchange. J. Chem. Phys. 1993, 98 (7), 5648-5652.

(11) Denis J.; Valerie W.; Eric A. P.; Adamo, C. Extensive TD-DFT Benchmark: Singlet-Excited States of Organic Molecules. J. Chem. Theory Comput. 2009, 5, 2420-2435.

(12) Jacquemin, D.; Perpète, E. A. Time-dependent density functional theory investigation of the absorption, fluorescence, and phosphorescence spectra of solvated coumarins. J. Chem. Phys. 2006, 125, 164324-164332.

(13) Zhang, W.; St-Gelais, F.; Grabner, C. P.; Trinidad, J. C.; Sumioka, A.; Morimoto-Tomita, M.; Kim, K. S.; Straub, C.; Burlingame, A. L.; Howe, J. R.; Tomita, S. A transmembrane accessory subunit that modulates kainate-type glutamate receptors. Neuron 2009, 61 (3), 385-396. 